QL150

-A 1

$\mathrm{P} 4$
PERKINS, J.

THE LEGUMINOSAE OF POUTO RICC. 


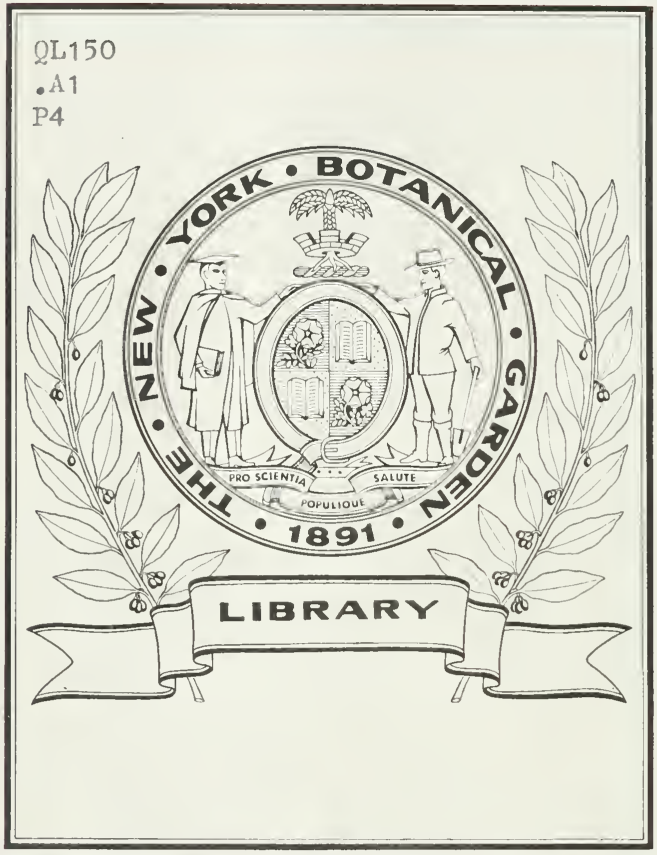




\title{
CONTREIBUTIONS
}

FROM THE

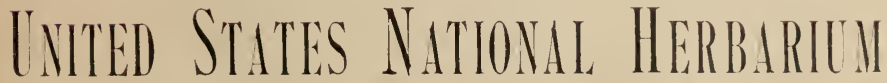

\author{
Volume X. Part 4
}

\section{THE LEGUMINOSAE OF PORTO RICO}

By J. PERKINS

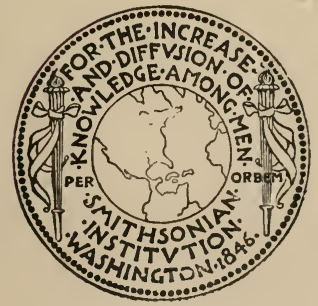

WASHINGTON

GOVERNMENT PRINTING OFFICE 

UNITED STATES NATIONAL MUSEUM

\section{CONTRIBUTIONS}

FROM THE

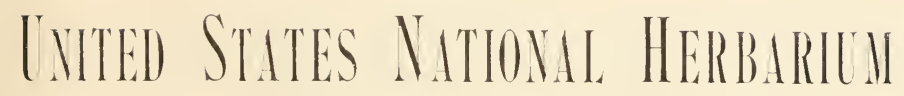

Volume X, PARt 4

\section{THE LEGUMINOSAE OF PORTO RICO}

By J. PERKINS

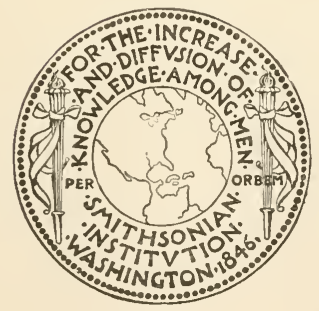

WASHINGTON

GOVERNMENT PRINTING OFFICE

1907 
BULLETIN OF THE INITED ST.ITE NITIONAL MUSEUM:

ISSUED JUNE 10,1907 . 


\section{PREFACE.}

In 1901 and 1902 Miss Janet Russell Perkins, Ph. D., under an appointment as scientific aid in the United States Department of Agriculture, was engaged at Berlin in a revision of the Leguminosae of Porto Rico. The revision was based upon a study of collections and literature, unaccompanied by field work in the island. It was originally intended to publish the results of this work conjointly with an account of the agricultural relations of the leguminous plants of that island, but as it proved to be necessary to postpone the preparation of this latter paper for more detailed investigation Miss Perkins's paper is now presented separately for publication.

This paper differs in several respects from the systematic treatment of leguminous plants presented in other numbers of these Contributions, and such differences must be taken only as an expression of the views of the author.

Frederick V. Coville, Curator of the United States National Herbarium. 



\section{CONTENTS.}

Yagt.

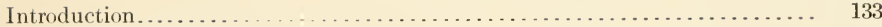

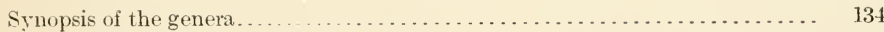

Descriptions of the genera and species........................ 140 



\section{THE LEGUMINOSAE OF PORTO RICO.}

By J. Perkins.

\section{INTRODUCTION.}

During the preparation of the following paper on the Leguminosae of Porto Rico the writer has been impressed with the small number of endemic plants. Of the 67 genera and 141 species only 1 genus (Stahlia) and 8 species (Cynometra portoricensis, Cassia stahlii, Cassia portoricensis, Sabinea punicea (introduced into Cuba according to Gundlach), Aeschynomene portoricensis, Lonchocarpus glaucifolius, Rudolphia volubilis, Schrantia portoricensis) are peculiar to the island.

With respect to distribution, the genera that appear in Porto Rico may be divided into four classes - those which occur in Porto Rico alone; those found also in several or many of the other Antilles; those that appear in Mexico, the Antilles, and South America; and, lastly, the cosmopolitans. In the third and fourth classes there are many genera, while the number in the first and second is comparatively sinall.

Very many of the valuable economic leguminous plants are found on the island. Among the most important are: Indigofera suffruticosa (indigo), Haematoxylon campecheanum (logwood, campechy wood), Pterocarpus officinalis (kino, American dragon's blood), Dolichos lablab (seeds and pods), Tigna unguiculata (pods, seeds, and fiber), Phaseolus vulgaris, Phaseolus lunatus, Cajanus indicus (seeds and young pods), Pachyrhizus erosus (tuberous root), Arachis hypogaea (oil and seeds), Abrus precutorius (red seeds used as ornaments, extremely poisonous), Adenanthera pavonina (red seeds (condori) used as ornaments, eaten cooked with rice), Albizzia lebbek (wood, gum, tanbark), Calliandra portoricensis (gum, "copaltic"), Hymenaea courbaril (gum, "American copal," wood), Stahlia monosperma (fine wood), Tamarindus indica (fruit, pulp), Acacia farnesiana (fragrant flowers, falsely known as "Cassia flowers," used in perfumery, roots and pods used for dyeing black and tanning), Clitoria ternatea, Sesbania grandiflora, Poinciana regia, Cassia fistula, Cassia grandis, Bauhinia kappleri, Caesalpinia gilliesii, Caesalpinia pulcherrima (ornamental plants). Inga vera, Erythrin $\mathrm{micropteryx}$, Pithecolobium saman, and others are used in shading coffee and cacao. 
A goodly number of tropical weeds are also represented here, some being cosmopolitan, others occurring only in America. Such are Mimosa pudica, Desmodium barbatum, D. triflorum (cosmopolitan), D. ascendens, D. axillare, D. supinum, D. spirale, Cassia tora (cosmopolitan), C. diphylla.

The economic facts and the vernacular names contained in the notes have been obtained from Watt, ${ }^{a}$ Urban, ${ }^{b}$ Cook and Collins, ${ }^{c}$ and many other reliable sources. In connection with the descriptions reference has been made to Cook and Collins, Economic Plants of Porto Rico, ${ }^{c}$ whenever those authors mention a species, give a plate, or use a name not adopted in this paper. A large number of the species described have been examined in the herbarium of the Royal Botanical Museum in Berlin, especially valuable being the duplicates of Sintenis, Schwanecke, and Bertero. From the herbarium material, from the great English floras, and from Bentham's classical monographs has been derived much information in regard to geographical distribution. It has undoubtedly been of service in preparing this paper that in various trips in the Tropies an opportunity has been given the writer of seeing, in a living condition, a large number of the plants described.

The nomenclature generally followed has been that of Urban, although at times the Kew Index names have been used. Since the appearance of Urban's Flora Portoricensis ${ }^{b}$ it has been necessary to interpolate several new forms and names and to reduce to synonymy a number of Bello's species. Likewise the lists of localities have been supplemented, as the material contained in the Berlin Herbarium was not so complete as that of the West Indian Herbarium of Professor Urban.

\section{SYNOPSIS OF THE GENERA.}

Flowers regular; petals valvate in the bud.

Mimosoideae.

Stamens indefinite, but at least more than 10 .

Stamens consolidated at the base or united and forming a tube; in several genera more than a single carpel. (INGEAE.)

Leaves pinnate; style 1.

1. Inga (p. 140).

Leaves bipinnate (pinnae sometimes 1jugate bearing 1 to 3 leaflets); style 1 .

Legume thick, compressed, coriaceous or somewhat fleshy, involute, curved, or almost straight, indehiscent or dehiscent with contorted valves, sometimes separating into 1-seeded joints.

2. Pithecolobium (p. 141).

$a$ Watt, George, A dictionary of the economic products of India, 18\$5-1893.

$b$ Symbolae Antillanae, volume 4, pp. 262 to 312.1905.

c contributions from the Inited States National Herbarium, volume 8 , pages 57 to $269,1903$. 
Legume flat, thin, indehiscent, or dehiscent with valves that are not contorted.

Legume straight or slightly curved; valves separating elastically longitudinally from apex to base.

Stamens free, the inner ones sometimes united, forming a very short ring; carpel always 1 . (ACACIEAE.)

Stamens (as many as or) twice as inany as petals.

Anthers eglandular. (Eummosea E.)

Valves of the legume separating from the persistent sutural replum.

Legume flatly compressed.

Legume subquadrangular.

Valves of the legume adhering to the sutural replum.

Legume narrowly linear; seeds longitudinal or oblique.

Legume broadly linear; seeds transverse.

Anthers in the bud bearing a sessile or more often stipitate gland, which usually has disappeared at the time of flowering.

Seeds with endosperm. (AdenantheREAE.)

Flowers capitate.

Flowers spicate or racemose.

Seeds without endosperm. (PiptadeNIEAE.)

Flowers in globose heads (in the Porto Rican species) or in spikes; legume flat, 2-valved, valves continuous, entire.

Flowers in spikes; legume straight or arcuate, sometimes of enormous size, woody, coriaceous, or papery; sutures more or less thickened, persisting after the separation of the 1 -seeded articulations as a replum.

Flowers zygomorphic, not papilionaceous; petals imbricate in the bud, the posterior one included in estivation.

Leaves abruptly pinnate; calyx lobes free to the disk; petals 0,1 , or 5 ; ovules 1 to 4 . (CrnomeTREAE.)

Leaves without black glandular dots; petals on the outside levigate; stamens usually glabrous.

Leaves on the under surface with black glands; petals on the outside verrucose: stamens lanate-pilose.
3. Albizzia (p. 142).

4. Calliandra (p.143).

5. Acacia (p. 144).

8. Mimosa (p. 147).

7. Schrankia (p. 146).

9. Desmanthus (p. 148).

6. Leucaena (p. 146).

10. Neptunia (p. 148).

11. Adenanthera (p. 149).

12. Piptadenia (p. 150).

13. Entada (p. 150).

Caesalpinioideae.

14. Cynometra (p. 151).

15. Stahlia (p. 151). 
Leaves simply pinnate, occasionally 2-foliolate; calyx-lobes free to the disk, or perianth reduced to scale or obsolete. (AMHerstreat.)

Leaflets 1-jugate.

Leaflets many-jugate.

Leaves simple, or 2-foliolate with more or less connate leaflets. (Bauninieaz.)

Leaves simply pinnate; sepals 5 , distinct or calyx lobes free to the disk; petals 5 or fewer or none; stamens 2 to 10 , anthers basifixed or dorsifixed. (Cassieate)

Leaves simple (rarely digitate); sepals 4 or 5 , nearly equal, imbricate, more or less corollaceous, the outer one somewhat larger than the others; petals 4 or 5 ; stamens 3 or 4 , the anthers basifixed, opening with oblique introrse pores. (KRAMERIEAE.)

Leaves bipinnate; calyx divided to the disk; petals usually 5 , subequal or but slightly unequal; stamens 10. (Eucaesalpinieate.)

Common petiole very short, spine-pointed; rachis of the pinnae very long, flat, phyllodineous.

Common petiole plainly developed, not phyllodineous.

Calyx segments valvate in estivation. Flowers showy.

Calyx segments strongly imbricate in estivation.

Legume dehiscing lengthwise in the middle of the valves.

Legume indehiscent or dehiscing lengthwise at the sutures.

Flowers zygomorphic, papilionaceous; posterior petal (standard) outside in the bud.

Stamens 10, all free. (Sophoreate)

Pods winged; leaves with pellucid glandular lines and dots.

Pods not winged.

A large tree; pods continuous.

A shrub; pods constricted between the seeds.

Stamens 10, monadelphous; pod 2-valved, not articulate; erect herbs or shrubs, with simple or digitately trifoliolate leaves. (GeNisteate)

Tube of the stamens slit along the top; style abruptly bent near the base.

Stamens 10, monadelphous or diadelphous; pod 2 -valvesl, not articulated; erect, rarely climbing herbs, shrubs, or trees with imparipinnate leaves. (GALEGEAE.)

Anthers with glandular, apiculate or penicillate-pilose comnective; plants with malpighiaceous hairs, i. e., appressed hairs attached by the middle. (INDIGOFERINAE.)
16. Hymenaea (p. 152).

17. Tamarindus (p. 152).

18. Bauhinia (p. 153).

19. Cassia (p. 155).

20. Krameria (p. 163).

21. Parkinsonia (p. 163).

23. Poinciana (p. 165).

22. Hfaematoxylum (p. 164).

24. Caesalpinia (p. 165).

Papilionatae.

25. Myrospermum (p. 16\$).

26. Ormosia (p. 16s).

27. Sophora (p. 169).

28. Crotalaria (p. 170).

29. Indigofera (p. 172). 
Connective not appendiculate; plants very rarely clothed with malpighiaceous hairs.

Seeds usually 1 or 2 , rarely 3 or 4 ; pod small, 1-seeded, indehiscent; herbs or shrubs with glandular dots. (PsoraLIINAE.)

Seeds usually several or more, rarely with glandular hairs, very rarely with glandular dots.

Inflorescence or racemes usually terminal, or terminal and axillary. (Tephrosinnae.)

Style not bearded (rarely a small tuit of hairs on the stigma in Tephrosia); petals with short claws.

Style bearded longitudinally inside; petals with very long claws; calyx long-tubuliform. Inflorescence always axillary; stipe of the ovary without a diseus at the base. (Robininneate)

Pod not septate within.

Leaflets without stipels; stigma terminal; stipules small setaceous.

Leaves imparipinnate. Leaves paripinnate.

Leaflets with small stipels; stigma below the somewhat hooked apex of the style; stipules stiff, sometimes spinous.

Pod with transverse partitions between the seeds.

Style long-bearded on the inner side.

Style glabrous.

Stamens 10, monadelphous or diadelphous; pod articulated; usually erect herbs or shrubs, with imparipinnate leaves. (Hedysàreat.)

Upper stamen free toward the middle or connate with the others from the base; leaflets stipellate. (DEsuodinat.)

Pod compressed, straight; calyx herbaceous.

Pod terete, straight; calyx glumaceous.

Stamens all united in a sheath more or less split on both the upper and the lower edges dividing the stamens into two bundles; flowers in axillary, usually few-flowered racemes, more rarely fascicled in the axils of the leaves; leaves pinnate; leaflets nu-
30. Dalea (p. 173).

31. Tephrosia (p. 174).

32. Barbieria (p. 175).

33. Gliricidia (p. 176).

35. Sabinea (p. 177).

34. Corynella (p. 177).

36. Cracea (p. 17S).

37. Sesbania (p. 179).

43. Desmodium (p. 185).

44. Alysicarpus (p. 191), 
merous, more rarely 1 to 3 , without stipels.

(AEschynomeninae.)

Stamen sheath split on the upper edge or entire.

Stamen sheath split on the under edge and soon after florescence also more or less on the upper edge.

Stamens all connate in a closed tube, the anthers alternately longer and fixed near the base and shorter and versatile; flowers in terminal or axillary spikes or heads, rarely somewhat racemose; leaves pinnate, usually with few leaflets, not stipellate. (SтуLOSANTHINAE.)

Calyx with an elongated filiform tube; leaves pinnate.

Pod small, distinctly articulated, hooked at the end, ripening in the air; leaves pinnate with only 3 leaflets; flowers small, terminal or axillary, in dense hispidulous spikes.

Pod large, not articulated, not hooked at the end, ripening in the soil; leaves pinnate, usually with 4 , seldom with 3 leaflets; flowers rather large, solitary, axillary with long pedicels.

Calyx tube not elongated; leaves digitate, with 2 or 4 leaflets.

Stamens 10, monadelphous or diadelphous; pod indehiscent; erect or scandent shrubs or trees, with imparipinnate leaves and entire leaflets.

(Dalbergieae.)

Pod membranous, papyraceous, or coriaceous to ligneous, often compressed and winged, in any case not drupaceous.

Leaflets alternate, rarely reduced to 1 . (Pterocarpinae.)

Anthers small, terminal, erect, the cells dehiscing by a small apical slit; pod suborbicular.

Anthers dorsifixed, opening longitudinally.

Calyx blunt at the base, bracteoles usually somewhat orbicular; standard silky outside; pod thickly coriaceous.

Calyx turbinate at the base; bracteoles small, deciduous; standard glabrous; pod papyraceous or thinly coriaceous, more or less incrassated in the center.
38. Pictetia (p. 180).

39. Aeschynomene (p. 181).

40. Stylosanthes (p. 183).

41. Arachis (p. 184).

42. Zornia (p. 185).

45. Dalbergia (p. 192).

46. Drepanocarpus (p. 193).

47. Pterocarpus (p. 194). 
Leaflets opposite, very rarely alternate, rarely reduced to 1 . (LONCHOCARPINAE.)

Pod not winged.

Pod with 4 wings.

Pod drupaceous. (Geoffraeinae.)

Stamens 10, usually diadelphous; pod 2-valved; leaves ending in a tendril. (VICIEAE.)

Stamens 10, diadelphous or monadelphous; pod 2-valved, not articulate; scandent (rarely erect) shrubs or herbs, with usually pinnately trifoliolate leaves, often stipellate. (PHASEOLEAE.)

Upper stamen free or more or less united with the others; style glabrous above, rarely pilose below, very rarely bearded longitudinally on the inner side (Clitoria); nodes of the racemes not swollen. (GLycininae.)

Style bearded longitudinally on the inner side.

Style glabrous.

Standard spurred over the claw or at least with a tubercle.

Standard without spur or tubercle.

Upper stamen free or more or less united; style glabrous or pilose below; either the standard or the keel very large, larger than the other petals. (ErxthrininaE.)

Standard the largest of the petals.

Leaves with 3 leaflets; calyx bilabiate or spathaceous, rarely equally 5-toothed; trees or erect shrubs.

Leaves with 1 leaflet; calyx with 4 segments, the two lateral small or indistinct; twining herbs.

Keel the largest of the petals.

Style glabrous or pilose below; upper stamen free; nodes of the racemes swollen. (Galactinate)

Calyx segments 5 , the upper one being 2 -toothed or bifid.

Calyx segments 4, the upper one consisting of 2 united.

Style glabrous or pilose below; upper stamen free at the base, above more or less connate with the others; nodes of the racemes swollen. (Diocleinat.)

Calyx with 4 subequal segments.

Calyx bilabiate, the upper lip very large, entire or bifid, the lower lip very small; the upper suture of the pod incrassated or 2-winged.

48. Lonchocarpus (p. 194).

49. Piscidia (p. 196).

50. Andira (p. 196).

51. Abrus (p. 197).

52. Clitoria (p. 198).

53. Centrosema (p. 199).

54. Teramnus (p. 201).

55. Erythrina (p. 202).

56. Rudolphia (p. 203).

57. Mucuna (p. 204).

58. Calopogonium (p. 206).

59. Galactia (p. 206).

60. Dioclea (p. 209).

61. C'anavalia (p. 209). 
Style glabrous or pilose below; upper stamen free; leaves gland-dotted. (CAJANINAE.)

Seeds 4 to many.

62. Cajanus (p. 210).

Seeds 2 , very rarely 3 .

63. Rhynchosia (p. 211).

Style bearded longitudinally on the inner side or penicillate at the apex. (PhaseoLINAE.)

Keel twisted spirally.

Keel truncate or with a curved beak, not spirally twisted.

Stigma subsessile, oblique, inflexed or inserted below the apex of the style.

Stigma very oblique, inflexed.

Stigma subsessile, on the inner side of the style which is dilated at the apex.

Stigma terminal, not oblique.

64. Phaseolus (p. 213).

65. Tigna (p. 216).

66. Pachyrhizus (p. 218).

67. Dolichos (p. 219).

\section{DESCRIPTIONS OF THE GENERA AND SPECIES.}

1. INGA Scop.

Inga Scop. Introd, 298, 1777.

1mosa Neck. Elem. 2: 459. 1790.

Flowers 5 or 6-merous; calyx tubular or campanulate, dentate or broadly lobed; corolla tubular or funnel-shaped, the petals connate to the middle or beyond it; stamens indefinite, more or less united and forming a tube, long-exserted; ovary sessile; seeds numerous; legume linear, straight or somewhat curved, flat, quadrangular or almost terete, coriaceous or somewhat fleshy, almost always with thickened sutures, sub-dehiscent, pulpy between the seeds or rarely without pulp.-Trees or shrubs with pinnate leaves; rachis winged between the leaflets or sometimes not, almost always bearing sussile or stipitate glands; flowers often very large and tomentose, in umbels or globose heads, sometimes in oval elongated spikes, solitary or in fascicles, axillary or in crowded compound racemes on the ends of the branches.

KEY TO THE SPECIES.

Stem, leaves, and flowers rusty brown tomentose or pubescent; rachis winged between the leaflets.

1. I. vera.

Stem, leaves, and flowers glabrous; rachis not winged between the leaflets.

\section{Inga vera Willd.}

2. I. laurina.

(Urban, 263.) $)^{a}$

A large tree; leaflets 4 to 6 -jugate, oval or elliptical-oblong, the largest $17 \mathrm{~cm}$. long, $7 \mathrm{~cm}$. wide, sessile, spikes 10 to $13 \mathrm{~cm}$. long; flowers 4.5 to $5.5 \mathrm{~cm}$. long; calyx $1 \mathrm{~cm}$. long; corolla $1.5 \mathrm{~cm}$. long; stamens white, legume about $20 \mathrm{~cm}$. long.

In woods near Bayamon; near dwellings on Nount Jimenez, at Sierra de Luquillo; near Los Mameyes; between Iguas Buenas and Caguas, along roads; on Mount Mesa, near Mayaguez,-Jamaica, Haiti, Trinidad (Griscbach), Central America, Colombia.

a The references under the species names are to the full synonymy given by Urban, Symbolae Antillanae, volume 4. All the pages cited, 262 to 312 , were issued in 1905 . 
Inga vera is used extensively for shade in coffee plantations. (Cook and Collins, p. 167.) The bark of the tree is employed as an astringent, and in fruadaloupe for tanning and dyeing; the sweet pulp is often eaten, and it is also used in catarrhal maladies.

Local names, guara, guaba.

\section{Inga laurina (Sw.) Willd.}

(Trban, 262.)

Tree 10 to 15 meters high; leaflets 2-jugate, ovate or oval-oblong, obtuse or obtuseacuminate, coriaceous, glabrous, the largest 7 to $12 \mathrm{~cm}$. long; spikes axillary, elongated; flowers white; calyx $1.5 \mathrm{~mm}$. long; corolla 5 to $6 \mathrm{~mm}$. long; legume oblique at the base, 7.5 to $10 \mathrm{~cm}$. long, $2.5 \mathrm{~cm}$. wide.

In woods near Bayamon; near Juncos on Mfount Goyo; Sierra de Yabucoa on Mfount Cerro Gordo; near Maunabo, on Mount Mala Pasqua in the town of Ltuado; near Cabo Rojo; near Mayaguez.-Haiti, St. Thomas, St. Croix (Eggers), St. John (Eggers), St. Kitts, Antigua, Guadeloupe, Dominica, Martinique, St. Lucia (Benthim), St. Vineent, Barbados, Grenada, Trinidad (Bentham).

According to Cook and Collins (p. 167) this species is second in importance only to Inga vera as a shade tree for coffee.

Local name, guama.

\section{PITHECOLOBIUM Mart.}

Pithecolobium Mart. Flora 20²: Beibl. 114. 1837.

Spiroloba RAF. Sylva Tellur. 119. 1838.

Cathormion Hassk. Retzia 1: 231. 1855.

Flowers 5-merous, seldom 6-merous, hermaphrodite, rarely polygamous; calyx campanulate or tubular, short-dentate; corolla tubular or funnel-shaped, petals connate beyond the middle; stamens indefinite, often connate: ovary sessile or stipitate, ovules numerous; legume compressed, circinate, curved, or almost straight, coriaceous or somewhat fleshy, two-valved, the valves after the dehiscence often twisted, oftener indehiscent or in some species separating into 1-seeded segments; seeds flat, ovate or circular, often imbedded in a fleshy pulp; funiculus filiform or forming an aril.-Trees and shrubs, the majority of which are unarmed, although many have thorny stipules; leaves bipinnate; flowers red or white; inflorescence capitate or spicate, axillary (or sometimes corymbose, racemose, or panicled at the extremities).

KEY TO THE SPECIES.

Leaflets glabrous beneath.

Pinnae 2 to 5 -jugate, leaflets 2 to 8 -jugate.

1. P. saman.

Pinnae 8 to 12 -jugate, leaflets 20 to 30 -jugate.

2. P. arboreum.

Leaflets pubescent beneath.

3. P. unguis-cati.

\section{Pithecolobium saman (Jacq.) Benth}

(Urban, 264.)

A large tree; leaflets oblique, ovate-oblong or suborbiculate, 2 to $5 \mathrm{~cm}$. long, 1.5 to $2.5 \mathrm{~cm}$. wide; flowers rose-colored, in a globose head; calyx $8 \mathrm{~mm}$. long; corolla 1.5 cm. long; legume 18 to $20 \mathrm{~cm}$. long, 1.25 to $2.50 \mathrm{~cm}$. wide.

Doubtfully indigenous. Near Bayamon at Cataño; near Manati on the way to Arecibo. ('uba, Jamaica (introduced, Bentham), St. Thomas (introduced, Eggers), St. ('rox (do.), Guadeloupe (cultivated), Martinique (cultivated), St. Lucia (Grisebach), Trinidad (Hart). Native country, Central and south America. 
Flowers and fruit, March to May. The pods are much eaten by cattle. According to Hart (cited in Cook and Collins, p. 221) "the tree gives a fine shade for 'Guinea grass' pastures and it is also an excellent one for planting in ordinary 'low-bite' pastures, both for the benefit of herbage and also as a shade for the cattle."

Local name, saman.

\section{Pithecolobium arboreum (L.) Urb.}

(Urban, 264.)

Forest tree 15 to 20 meters high, unarmed; leaflets oblique, falcate-oblong, somewhat obtuse, shining, dark green, 10 to $12 \mathrm{~mm}$. long, $3 \mathrm{~mm}$. wide; flowers whitish green in globose heads; calyx $2.5 \mathrm{~mm}$. long; corolla $6.6 \mathrm{~mm}$. long; legume red, 7 to $8 \mathrm{~cm}$. long, $7 \mathrm{~mm}$. wide; seeds black.

In woods near Bayamon; near Cayey at Las Cruces; near Utuado, in rocky districts at Los Angeles; near Mayaguez; near Quebradillas.-Cuba, Jamaica, Haiti, Mexico, Central America.

Local names, cojoba, cojóbana.

\section{Pithecolobium unguis-cati (L.) Benth.}

(Urban, 263.)

Tree 3 to 5 meters high, armed; leaflets obovate, orbicular or broadly oblong, strongly oblique, obtuse, 4 to $5 \mathrm{~cm}$. long, 1 to $3 \mathrm{~cm}$. broad; flowers whitish, in elongated heads; calyx 1 to $2 \mathrm{~mm}$. long; corolla 6 to $7 \mathrm{~mm}$. long; legume 10 to $12 \mathrm{~cm}$. long, $7 \mathrm{~mm}$. wide.

On the coast near Fajardo; near Ponce at Tallaboa in thickets; near Guanica on declivities at Punta de la Meseta; near Salinas de Cabo Rojo in woods on the coast.South Florida (Chapman) and Keys, Bahama, Cuba (A. Richard), Jamaica, Haiti, St. Thomas, St. Croix, St. John (Eggers), St. Bartholomew (Stockholm Herbarium), Barbuda, St. Kitts, Antigua (Grisebach), Guadaloupe, Les Saintes (Duss), Marie Galante (do.), Dominica, Martinique, St. Lucia (Grisebach), St. Vincent (do.), Bequia, Mustique (Kew Bull. no. 81, p. 250), Union (do.), Barbadoes, Grenada, Trinidad, Venezuela, New Grenada.

The bark of $P$. unguis-cati is a much-valued medicament, and it is this tree that furnishes the siliciferous wood of the Antilles.

Local names, uña de gato, rolon, black bead; near Guayanilla called "escambron colorado" (Cook and Collins).

\section{ALBIZZIA Duraz.}

Albizzia Duraz. Mag. Tosc. 34: 11. 1772.

Flowers usually 5-merous, hermaphrodite or more rarely polygamous; calyx tubular or campanulate, toothed or shortly lobed; corolla funnel-formed; petals united onehalf their length or more; stamens indefinite, united at the base only or in a longexserted sheath; legume broadly linear, straight, flat, thin, indehiscent, or dehiscent with 2 inelastic valves not contorted after dehiscence, continuous, without pulp.Trees or shrubs unarmed; leaves bipinnate, leaflets small and numerous or few and large; flowers white, rose, rarely purple, in globose heads or cylindrical spikes, axillary or racemose toward the extremities.

\section{Albizzia lebbek (L.) Benth. ${ }^{a}$}

(Urban, 264.)

Tree, unarmed; pinnae 2 to 4 -jugate; leaflets, 5 to 9 -jugate, oval-oblong or oblong, 3 to $4 \mathrm{~cm}$. long, 1 to $1.5 \mathrm{~cm}$. wide, unequal sided, very obtuse, the petiole bearing an 
oval gland above its base; flowers white, pedicellate, in long-peduncled clusters; calyx $6 \mathrm{~mm}$. long; corolla $9 \mathrm{~mm}$. long; legume flat-compressed, indehiscent or the valves tardily separated, glabrous 18 to $36 \mathrm{~cm}$. long, 2.5 to $3.5 \mathrm{~cm}$. wide.

Seemingly spontaneous and cultivated near Bayamon; near Cataño; near Yabucoa on the coast; near Coamo along roads toward Baños; near Mayaguez at Algarrobo.Bahama, Cuba (Grisebach), Jamaica, Haiti, St. Thomas, St. Croix, St. Martin (Stockholm herbarium), Antigua (Grisebach), Guadeloupe, Martinique, St. Vincent, Bequia (Kew Bull. no. 81, p. 250), Trinidad, Curaçao. Native country, southern and eastern Asia, tropical Africa.

Albizzia lebbek is an ornamental tree that is exceedingly good for avenues. Its roots do not penetrate very deep. It grows rapidly, flourishes in almost any soil, and may be propagated by cuttings. The wood seasons, works, and polishes well and is fairly durable, while the bark is used as a tan bark. From this tree is procured a gutm that is said not to be soluble in water, but to merely form a jelly; it resembles gum arabic.

Local names, amor platonico, flamboyán. The last name is used for Albizzia lebbek, as well as for Poinciana regia, according to Urban.

\section{CALLIANDRA Benth.}

Anneslia SAlisb. Parad. Lond. pl. 64. 1807.

Annesleya G. Dos, Hist. Dichl. Pl. 2: 396. 1832, as section.

Calliandra Benth. Hook. Journ. Bot. 2: 137, 138. 1840.

Flowers 5 or 6-merous, polygamous; calyx campanulate, toothed, rarely deeply divided; corolla campanulate or funnel-form, segments united to the middle; stamens indefinite, connate at the base or beyond it, much exserted, glandular-hairy, the anthers rarely glabrous; legume linear, straight or somewhat curved, narrowed at the base, flat, continuous, the sutural margins prominent, seldom terete, 2 -valved, the valves separating elastically from apex to base.--Shrubs or small trees, usually armed; stipules membranaceous or foliaceous, persistent, sometimes transformed into thorns; leaves bipinnate; flowers showy, red or white, often with very long stamens, solitary or axillary.

\section{KEY TO THE SPECIES.}

Shrub, unarmed; pinnae 2 to 4 -jugate; leaflets 10 to 25 -jugate; calyx deeply toothed, ciliate on the margin; petals united only a little above the base, outside glabrous.

Shrub, armed; pinnae 1-jugate; leaflets 4 to 9-jugate, rarely 13-

1. C. portoricensis. jugate; calyx shortly toothed, glabrous; corolla united twothirds or three-fourths of its length, outside densely sericeouspilose.

\section{C. haematostoma.}

1. Calliandra portoricensis (Jacq.) Benth.

(Urban, 265.)

Shrub 1 to 4 meters high or tree 8 meters high, unarmed; leaflets linear or linearoblong, 5 to $12 \mathrm{~mm}$. long, glabrous; peduncle very slender; flowers white; calyx 2.5 $\mathrm{mm}$. long; corolla $10 \mathrm{~mm}$. long; legume linear, straight, 7 to $12 \mathrm{~cm}$. long, $8 \mathrm{~mm}$. wide, chartaceous, glabrous.

In woods and copses near Bayamon; near Fajardo on Mount Mula; near Juncos on calcareous mountains toward Florida, near Humacao; near Maunabo on Mount Mala Pasqua; near Cayey on the upper and lower Maton River and at Planaje and on Mount Cedro; near Coamo at Farajones, near Peñuelas on calcareous mountains near TallaboaPoniente; near Guaniea at El Manicl; in moist land on the edge of the forest between 
Barina and La Boca, and in the coast districts near Laguna; near Lares on declivities at Barrio Piletas; near Quebradillas; between Isabela and Quebradillas; near Toa Baja.-Bahama (Hitchcock), Cuba (Grisebach), Jamaica, Haiti, Vieques (Eggers), St. John, Grenada. Tropical continental America, tropical western Africa.

This shrub yields a gum, copaltic, that is used as a medicament in the West Indies. Local names, cojobillo, morir vivir cimarron, zarza boba (Urban); acacia puertoriqueña (Cook and Collins).

\section{Calliandra haematostoma (Bertero) Benth.}

(Ưrban, 265.)

Shrub, armed; 2 to 3 meters high; leaflets oblong, obtuse, 3 to $7 \mathrm{~mm}$. long, glabrous, subciliate; peduncle very short; stipules spiny or with spines at their base; corolla $5 \mathrm{~mm}$. long; stamens red; anthers white; legume 8 to $10 \mathrm{~cm}$. long, linear, villouspubescent, coriaceous.

Near Guayanilla, on calcareous rocks of the coast at Peñon, rare.-Bahama (Bentham), Cuba (Bentham), Jamaica, Haiti, St. Thomas in Flaghill, not often found, with flowers in October (Eggers).

\section{ACACIA Willd.}

Sassa uRUCE; J. F. Gmelin, Syst. 2: 1038, 1791.

Acacia Willd. Sp. Pl. 4: 1049. 1806.

Phyllodoce Lisk, Handb. 2: 132. 1831.

Flowers hermaphrodite or polygamous; calyx campanulate, toothed or lobed, the sepals seldom distinct or wanting: petals free or united, more or less connate, rarely united with the stamens, rarely wanting; stamens numerous, free or slightly and irregularly consolidated at the base: ovary sessile or stipitate, 1 to many-seeded; legume oval, linear or oblong, straight, curved or twisted, flat, convex or terete, membranous, coriaceous or woody, 2-valved or indehiscent, continuous or septate within, rarely with pulp, very seldom separating into segments; seeds usually oval, compressed, often with an aril.

Trees, rarely herbs, unarmed or with prickles or thorns; leaves bipinnate, with multijugate leaflets, or reduced to a phyllodium; sten glands more or less conspicuozs; stipules snall or wanting, membranous, rarely transformed into a curved thorn; flower-heads pedunculate, yellow, rarely white, 1 or 2 -fasciculate in the axils of the leaves, or racemose at the extremities.

KEY TO THE SPECIES.

Armed.

Ligneous plant, sometimes scandent: stem, branches, and pedunele armed with small recurved prickles; pinnae 6 to 12 jugate; leaflets 15 to 40 -jugate; legume-stipitate, 10 to $20 \mathrm{~cm}$. long, 1 to $1.5 \mathrm{~cm}$. wide, glabrous or glauco-tomentose, thin. small tree or slirul); stipular spines slender, straight; pinnae 2 to 8 ; leaflets 10 to 25-jugate; legume sessile, turgid, cylindrical or subfusiform, straight or eurved, glabrous, 5 to $7 \mathrm{~cm}$. long, $9 \mathrm{~mm}$. wide.

1. A. riparia. Tnarmed.

Tree; flowers spicate; pinnae 4 to 6 -jugate; leaflets 10 to 16 jugate, oxate-elliptic or broadly oblong, oblique, obtuse, at length coriaceous, $1 \mathrm{~cm}$. leng, $5 \mathrm{~mm}$. wide.

3. A. nudiflora. 
1. Acacia riparia $H . B . K$.

(Urban, 266.)

Shrub 2 to 8 meters high or tree 15 meters high; leaflets oblong, linear, $5 \mathrm{~mm}$. long, $1 \mathrm{~mm}$. wide; flowers white; corolla 2.2 to $3.3 \mathrm{~mm}$. long.

Near Bayamon, in thickets; near Juncos, on Mount Florida; near Maunabo, on Punta de la Tuna and near Punta Mala Pasqua; near Cayey on Morillos Brook; near Coamo, in thickets on the Yuey River toward Salinas; near Guanica, in thickets on the coast around the lagoon; near Cabo Rojo, on hills toward Guanajibo; near Mayaguez, on the slopes of Mount Mesa; near Maricao, on Mount Alegrillo; near Añasco; near Rincon, on the mountains at Calvache; near Aguadilla in thickets.-Jamaica (Grisebach), Haiti (Lamarck Herbarium), St. Thomas, St. Croix (West), St. Martin (Stockholm Herbarium), St. Bartholomew (do.), Antigua (Grisebach), Guadeloupe, Martinique, St. Vincent, Grenada, Trinidad, tropical South America.

Local name, zarza.

\section{Acacia farnesiana (L.) Willd.}

(Urban, 265.)

A large shrub; leaflets linear, $6 \mathrm{~mm}$. long, $1 \mathrm{~mm}$. wide.

Near Bayamon, in gardens; near Coamo, about Los Baños; near Guanica on Mount Puerco; near Cabo Rojo, at Salinas in forests on the seashore and at Puerto Real; near Añasco, on Tula range.-Bahama, Cuba, Jamaica (Grisebach), Haiti, St. Thomas, St. Croix, St. John (Eggers), St. Martin (Stockholm Herbarium), St. Bartholomew (Stockholm Herbarium), Antigua (Grisebach), Guadeloupe, Dominica, Martinique, St. Lucia (Grisebach), St. Vincent, Barbados, Grenada, Tobago, warmer regions of the earth.

So generally cultivated for the perfume of its flowers and so frequently established as an escape from cultivation, that it is difficult to determine where it is really indigenous. It appears, however, to be so in western America, from northern Chile to Texas, not, perhaps, in Brazil nor Guiana.

Abundant in tropical and subtropical northern central Australia, and in the interior of northeastern Australia, and perhaps also really indigenous in south tropical Africa, but introduced only in East India, northern tropical Africa, and the Mediterranean region.

The roots and pods of this plant have an alliaceous odor and in the Antilles are used for tanning, dyeing black, and in baths. The fragrant flowers (in trade falsely known as cassia flowers-cassie of the French) are much used in the making of perfumery. A gum exudes from the stem in considerable quantities. It is considered superior to gum arabic in the arts and in medicine. The wood is white, close-grained, hard, and tough.

Local name, aromo.

\section{Acacia nudiflora Willd.}

(Urban, 266.)

Tree 8 to 15 meters high; flowers white or yellow-white, later becoming brown; legume shortly stipitate, straight or a little curved, flat, $10 \mathrm{~cm}$. long, 1.3 to $1.9 \mathrm{~cm}$. wide, the valves coriaceous.

Near Fajardo, on the mountains toward Ceiba and in clayey soil of the seashore; near Naguabo, in forests on the coast at Candelero; near Yabucoa, in thickets on the coast at Puerto de la Vaca.-Haiti (Grisebach), St. Thomas, St. John (Bentham), Antigua (Grisebach), Gaudeloupe, Dominica, Martinique.

Local names, cojoba, cojóbana, tamarindo cimarron (Urban); acacia nudosa (Cook \& Collins). 


\section{LEUCAENA Benth.}

Leucaena Benth. Hook. Journ. Bot. 4: 416. 1842.

Flowers 5-merous, sessile, usually hermaphrodite; calyx tubular-campanulate, dentate; corolla free; stamens 10 , exserted; ovary stipitate, multiovulate; style filiform; legume stipitate, broadly linear, flat, coriaceous, 2-valved, the valves continuous; seeds flat, ovate, transverse.-Trees or shrubs, unarmed; leaves bipinnate, the rachis with or without glands; the leaflets small, multijugate, or large and paucijugate; stipules minute; flower-heads white, axillary, fascicled, or racemose at the extremities.

\section{Leucaena glauca (L.) Benth.}

(Urban, 266.)

Tree 10 to 20 meters high, rarely a shrub, unarmed; pinnae 4 to 8 -jugate; leaflets 10 to 20 -jugate, oblong-linear, pointed, oblique at the base, 11 to $16 \mathrm{~mm}$. long, $4 \mathrm{~mm}$. wide; flowers minute, white; legume glabrous, 10 to $15 \mathrm{~cm}$. long; seeds compressed, transverse to the valves.

Near Bayamon, in mountain forests and thickets; near Comerio, in thickets; near Coamo, in the valley of Quebrada, Morena brook; near Guanica, in the forest of Mount El Maniel; near Mayaguez.-Bermuda, Bahama, Cuba, Jamaica, Cayman (Hitchcock), Haiti, St. Thomas, St. Croix, St. John (Eggers), St. Martin (Stockholm Herbarium), St. Kitts, Antigua (Grisebach), Guadeloupe, Dominica, Martinique, St. Vincent, Bequia (Kew Bull. no. 81, p. 250), Mustique-(do.), Barbados, Grenada, Tobago, Trinidad, Curaçao. In the warmer regions of both hemispheres, but probably indigenous only in tropical America.

The firm wood of Leucaena glauca is used for making tools, and the young fruit and the ripe seeds are eaten raw with rice. By some authors given as a tree (Urban), by others as a shrub (Stahl, cited by Cook and Collins, p. 175).

Local names, acacia pálida (Urban); hediondilla fr'ook and Collins).

\section{SCHRANKIA Willd.}

Schrankia Willd. Sp. Pl. 4: 1041. 1806, not Medic. 1792.

Leptoglottis DC. Mem. Legum. 451. 1825.

Schranckia Benth. Hook. Journ. Bot. 4: 413.1842.

Morongia Britron, Mem. Torr. Club 5: 191. May, 1894.

Flowers 5 or 4-merous, pedicellate, hermaphrodite or polygamous; calyx minute; corolla funnel-form, the segments connate to the middle; stamens twice as many as the petals, free or cohering at the base, exserted; ovary subsessile, multiovulate; style filiform; legume linear, subquadrangular, aruleate throughout with spreading prickles, the valves separating from the persistent sutural replum; seeds oblong, quadrangular.-Herbs or undershrubs, armed with short recurved prickles; leaves bipinnate; flower-heads globose, white or purple, axillary, solitary or fascicled, the stamens in the male flowers often flatly compressed.

\section{Schrankia portoricensis Urb. $a$}

(Urban, 267.)

Shrub, climbing; branches glabrous or at leaf insertions slightly hairy; leaves 7 to $12 \mathrm{~cm}$. long with petioles 3 to $4 \mathrm{~cm}$. long; pinnae 4 to 7 -jugate; leaflets 15 to 20 -jugate, linear, obtuse or somewhat acute, 3 to $6 \mathrm{~mm}$. long, the veins inconspicuous, glabrous; flower heads axillary, solitary, 6 to $8 \mathrm{~mm}$. in diameter, light yellow; calyx 
minute, $\frac{1}{7}$ as long as the corolla, cupulate, slightly divided, with 6 to 8 substipitate glands on the margin; corolla $3 \mathrm{~mm}$. long; legume subsessile, 4 to $5 \mathrm{~mm}$. in diameter, 1.5 to $4 \mathrm{~cm}$. long, aculeate; seeds subrectangular, 4.5 to $5 \mathrm{~mm}$. long, $2.5 \mathrm{~mm}$. wide, black.

Near Coamo, in the mountain forests of San Ildefonso and on shady slopes in El Tendal Valley. Indigenous.

Local name, cuernecillo.

\title{
8. MIMOSA L.
}

Mimosa L. Sp. Pl. 1: 516. 1753.

Lomoplis Raf. Sylva Tellur. 118. 1838.

Flowers 4 or 5 , rarely 3 to 6 -merous, hermaphrodite or polygamous; calyx usually small, sometimes wanting or paleaeform, often laciniate or fimbriate, rarely campanulate and short-toothed; corolla campanulate or funnelform; stamens (as many as or) twice as many as the petals, free, exserted; ovary sessile or substipitate, 2 to many-seeded; style filamentose; legume oblong or linear, compressed, rarely incrassated, membranous or coriaceous, valves separating entire or in transverse segments from the persistent sutural replum: seeds ovate or oblong, flat.-Decumbent or erect herbs, scandent undershrubs, or trees, unarmed or aculeate; leaves bipinnate, rarely wanting or reduced to a leaflike stem; petiolar glands present; flowers small, in globose heads or cylindrical spikes, axillary or racemose toward the extremities, solitary or fascicled.

KEY TO THE SPECIES.

Pinnae 2 -jugate, rarely 1 -jugate; leaflets 15 to 25 -jugate; petiole and peduncle unarmed; legume 1.5 to $2 \mathrm{~cm}$. long, $4 \mathrm{~mm}$. wide, covered with recurved bristles.

1. M. pudica.

Pinnae 3 to 5-jugate; leaflets 3 -jugate; petiole and peduncle armed; legume 5 to $5.5 \mathrm{~cm}$. long, $2 \mathrm{~cm}$. wide, with large recurved prickles on the margins.

\section{Mimosa pudica L.}

\section{M. ceratonia.}

\author{
(Urban, 267.)
}

Undershrub or an herb, often scandent, armed with infrastipular and scattered prickles; leaflets oblong-linear, pointed, ciliate with adpressed bristles, glabrescent, 10 to $11 \mathrm{~mm}$. long, $2 \mathrm{~mm}$. wide, membranous; flower-heads oval.

Near Bayamon; near Maricao, along roads; near Mayaguez, around the fortress.Cuba, Jamaica, Haiti, St. Thomas, St. Croix, St. Kitts (Grisebach), Antigua (do.), Guadeloupe, Martinique, St. Lucia (Grisebach), St. Vincent, Grenada, Tobago, Trinidad. Continental tropical America, tropical Asia, probably introduced.

A common weed in most parts of the region, naturalized also in many parts of tropical Africa.

A medicament is made from the roots, leaves, and seeds of Mimosa pudica that is used by the country people.

Local names, morivivi, morir-vivir, sensitiva. Sensitive plant.

\section{Mimosa ceratonia L.}

(Urban, 267.)

Shrub 4 meters high, decumbent or ascending; branches and petioles armed with small recurved prickles; leaflets obovate or orbiculate, 1.5 to $2.5 \mathrm{~cm}$. long, membranous, 3-nerved; flower-heads globose, racemose toward the extremities; "white.

Near Bayamon; near Yabucoa, in mountain woods at Guayabota; near Maunabo, in thickets at Punta de la Tuna; near Mayaguez, on the slopes of Mount Mesa; near Manati 
in the primeval forest of Mount Mala Pasqua.-St. Thomas, St. Croix (West), Antigua (Grisebach), Gaudeloupe, Dominica, Martinique, St. Lucia (Bentham), St. Vincent.

This plant is perhaps found on the South American continent, but $M$. obovata is often mistaken for it.

Local name, zarza.

\section{DESMANTHUS Willd.}

Acuan Medic. Theod. 62. 1786.

Desmanthus Wruld. Sp. Pl. 4: 1044. 1805.

Desmanthea DC. Prod. 2: 444. 1825, as section.

Flowers 5-merous, sessile, hermaphrodite or the lower ones male or neuter; calyx campanulate, shortly toothed; petals free or slightly cohering; stamens 10 or 5 , free, exserted; ovary subsessile, multiovulate; style subulate, or sometimes incrassate above; stigma terminal, truncate, concave; legume linear, straight or curved, compressed, continuous or slightly septate, 2-valved, the valves adhering to the sutural replum; seeds compressed, subrhomboidal. Perennial herbs or undershrubs; leaves bipinnate, leaflets small; stipules setaceous, persistent; flower-heads subglobose, often pauciflorous, solitary, axillary.

\section{Desmanthus virgatus (L.) Willd.}

(Urban, 268.)

Undershrub, decumbent or ascending, 2 to 3 meters high; pinnae 1 to 7 -jugate, petiole bearing an ovate-oblong gland between the lowest pair; leaflets 10 to 20 -jugate, oblonglinear, 5 to $8 \mathrm{~mm}$. long, $2 \mathrm{~mm}$. wide; flower-heads with a few white flowers, 5 to $9 \mathrm{~mm}$. in diameter; legume straight or slightly falcate, 6 to $8 \mathrm{~cm}$. long, $2 \mathrm{~mm}$. wide, 20 to 30 -seeded.

Near Guanica, on the seashore at Caño Gordo and on dry grassy tracts around the lagoon; near Mayaguez, at the fortress.-Bermuda (Hemsley), Cuba, Jamaica, Haiti, Gaudeloupe, Martinique, Grenada. Tropical and subtropical America; common from Buenos Ayres to the West Indies. Tropical Asia; probably introduced into East India.

Local name, desmanto rayado.

\section{Desmanthus virgatus strictus (Bertol.) Griseb.}

(Urban, 268.)

Shrub 0.5 to 2 meters high or small tree 3 to 4 meters high; flowers white.

Near Fajardo, on roadside; near Aibonito, between Algarrobo and Cariblanco; near Coamo, about Salinas; near Peñuelas, on shady slopes of Mount Llano; near Guanica, on the margins of woods between La Boca and Barinas and about lagoons; near Salinas de Cabo Rojo, in the coast districts, near Iguadilla.-Bahama, Cuba, Haiti, St. Thomas, St. Croix, St. Bartholomew (Stockholm Herbarium), Martinique, St. Vincent, Barbados, Tobago.

Variety strictus in Porto Rico and also in the other islands differs obviously from the type and is easily listinguished from it.

\section{NEPTUNIA Lour.}

Neptunia Lour. F1. Cochincl. 2: 653. 1790.

Hemidesma RAF. Sylva Tellur. 119. 1838.

Flowers 5-merous, sessile, the upper hermaphrodite, the lower masculine or neuter; calyx campanulate, shortly toothed; petals cohering to the middle or free; stamens 10 , rarely 5, exserted; ovary sessile, multiovulate; style filiform, with a small, terminal, concave stigma; legume shortly and broadly oblong, oblique and almost at right angles with the short stipes, the apex rounded but with a distinct apiculum, compressed, thinly 
coriaceous or submembranous, 2-valved, the valves depressed between the seeds or indistinctly septate; seeds transverse, ovate.-Perennial herbs or decumbent or aquatic undershrubs, stems usually compressed or triangular; leaves bipinnate, the leaflets small; stipules membranous, obliquely cordate; flower heads ovat e-globose, axillary, solitary, the lower neuter flowers with elongated petaloid staminodia.

\section{Neptunia plena (L.) Benth.}

(Urban, 268.)

Undershrub, decumbent or ascending; pinnae 2 or 3 -jugate, the petiole bearing a gland between the lowest pair; leaflets 14 to 20 -jugate, narrowly linear, 4 to $7 \mathrm{~mm}$. long, $2 \mathrm{~mm}$. wide; bracts in the middle of the peduncle alternate, cordate, longer persistent than in other species; flower-heads oval, the flowers yellow, the calyx $2 \mathrm{~mm}$. long; corolla $3.5 \mathrm{~mm}$. long; anthers brown; legume stipitate, at length deflexed, 3 to 4 $\mathrm{cm}$. long, $1 \mathrm{~cm}$. wide, 5 to 20 -seeded.

Near Maunabo, at Punta de la Tuna; near Guanica, on the swampy shore of the lagoon toward La Plata; between Vega Baja and Dorado, in sandy districts; near Dorado, on inundated sandy land.-Cuba (Richard), Jamaica (Grisebach), Haiti, Antigua (Grisebach), Guadeloupe, Martinique, St. Vincent, Union (Kew Bull. no. 81, p. 249), Grenada, Curaçao, South America, tropical Asia (introduced).

The plant figured in the Botanical Register $a$ as $N$. plena, and described as having a spongy floating stem, was probably $N$. oleracea.

Local name, desmanto amarillo.

\section{ADENANTHERA L.}

\section{Adenanthera L. Sp. Pl. 1: 384. 1753.}

Stachychrysum Boj. Hort. Maurit. 114. 1837.

\section{.} Gonsii ADAns. Fam. 2: 318. 1763.

Flowers hermaphrodite or polygamous, 5-merous, substipitate; calyx campanulate, shortly toothed; corolla segments coherent below or free; stamens 10, free, scarcely exserted; ovary sessile, multiovulate, style filiform, stigma small, terminal; legume linear, usually curved, compressed or often turgid over the seeds, usually incurved or falcate, 2-valved, usually septate; seeds scarlet or two-colored, thick, the testa hard, smooth.-Trees, unarmed; leaves bipinnate; leaflets small, multijugate; flow ers white or yellowish; racemes often elongated, solitary or fascicled in the axils or panicled at the extremities.

\section{Adenanthera paronina L.}

(Urban, 269.)

Tree, 5 to 8 meters high; pinnae 2 to 5 -jugate; leaflets 6 to 10 -jugate, ovate or oblongelliptical, 2.6 to $5 \mathrm{~cm}$. long, 1 to $2.5 \mathrm{~cm}$. broad, very obtuse, glabrous; flowers in racemes; calyx $1 \mathrm{~mm}$. long; corolla $3.5 \mathrm{~mm}$. long; legume 10 to $27 \mathrm{~cm}$. long, 1 to 1.5 $\mathrm{cm}$. wide, brown outside, golden yellow inside, linear, compressed, incurved; seeds scarlet, smooth.

Cultivated and seemingly spontaneous near Bayamon; near Cabo Rojo; near Mayaguez; near Añasco, around Hacienda Pagan.-Cuba (Grisebach), Jamaica (do.), Cayman (Hitcheock), St. Thomas (Eggers), St. Croix (do.), St. John (do.), Guadaloupe, Martinique (Duss), St. Vincent, Bequia. Native country tropical Asia.

This plant is introduced in the ITest Indies and other parts of tropical America, and possibly in tropical Africa and tropical Australia. The glistening red seeds (condori) are worn as ornaments by the women and, roasted or boiled with rice, they are used as 
food. From the roots in Cuba and IIaiti an emetic is made, and a remedy used for rheumatism is procured by boiling the leaves. The wood is sometimes used as a dye, but chiefly as a substitute for the true red sandalwood. The heartwood is red, hard, closegrained, durable, and strong, and is used for house building and cabinet making.

Local names, coralitas, mato, mato colorado, palo de mato, peronilas.

\section{PIPTADENIA Benth.}

Piptadenia Benth. Hook. Journ. Bot. 4: 334. 1842.

Schleinitzia WARB. Engl. Bot. Yahrb. 13: 336. 1891.

Flowers sessile, 5-merous; calyx campanulate, shortly toothed; corolla connate to the middle; stamens 10, free, exserted; ovary subsessile; ovules 3 to many; legume stipitate, rarely sessile, broadly linear, flat, membranaceous or subcoriaceous, 2-valved, the valves continuous, without pulp; seeds compressed; funiculus filiform.-Trees or shrubs, unarmed or aculeate; leaves bipinnate; leaflets small, multijugate, rarely large and paucijugate; flowers small, white or greenish, cylindrically spicate or globosecapitate, solitary or fascicled, axillary or panicled at the extremities.

\section{Piptadenia peregrina (L.) Benth.}

(Urban, 269.)

Shrub 4 meters high or tree 20 meters high, unarmed; pinnae 15 to 30 -jugate, leaflets 30 to 80 -jugate, minute, 2 to $4 \mathrm{~mm}$. long, 1 to $1.5 \mathrm{~mm}$. wide, linear, glabrescent; petiole puberulous, bearing a gland above the base; flower heads white, small; calyx $1.5 \mathrm{~mm}$. long; corolla $3.5 \mathrm{~mm}$. long; legume 5 to $15 \mathrm{~cm}$. long, $1.5 \mathrm{~cm}$. broad, subcoriaceous, 2 valved.

Near Bayamon, in mountain woods at Toa Baja; near Aibonito, on slopes near Buena Vista de la Plata; near Sabana Grande, on the Estero River; near Cabo Rojo, toward Guanajibo; near Mayaguez; near Rincon, at Barrio del Pasto; Manati, in thickets near Garrochales.-Haiti, Dominica, St. Vincent (Grisebach), Trinidad (Bentham). Tropical America: Brazil, provinces of Rio Janeiro, Minas Geraes, Goyaz, and Rio Negro; Guiana, Venezuela.

Local names, eojóbana, cojoba, cojobillo, cojobo.

\section{ENTADA Adans.}

\section{Entada ADANs. Fam. 2: 318. 1763.}

Flowers spicate, 5-imerous, sessile or shortly pedicellate; calyx campanulate, toothed or deltoid-lobate; petals free or coherent at bàse, oblong-lanceolate or linear, valvate; stamens 10 , usually exserted, the anthers elliptical or roundish with a terminal caducous gland; pollen-grains indefinite; ovary subsessile, multiovulate; style filiform; stigma terminal, truncate, concave; legume straight, sometimes of enormous size; seeds flattened, exalbuminous; testa with a central areole.-Trees or climbing shrubs, unarmed; leaves bipinnate, the number of pinnae and of leaflets very variable; spikes solitary or fascicled from the upper axils, or panicled at the extremities; hermaphrodite or polygamous.

\section{Entada polyphylla Benth.}

(Urban, 269.)

A large shrub 5 meters high; pinnae 4 to 8 -jugate; leaflets 12 to 20 -jugate, linearoblong, obtuse, retuse, clothed beneath with short adpressed hairs; spikes numerous in terminal racemes, rachis and petioles puberulent: legume $7.5 \mathrm{~cm}$. long. 
Near Fajardo, on the river at the base of Mount Mula; between Manati and Vega Baja, in sandy districts. - South America, and in related forms in Guadeloupe, Martinique, and St. Vincent.

Local name, tamarindilln.

14. CYNOMETRA L.

Cynometra L. Sp. Pl. 1: 382. 1753.

Iripa ADAns. Fam. 2: 508. 1763.

Cynomora R. Henwig, Gen. 304. 1806.

Metrocynia Thou. Gen. Nov. Madag. 22. 1806.

Calyx with a rather short or very short receptacle; segments 4 or 5 , thin, imbricate in estivation, usually reflexed at flowering; petals 5, subequal, sometimes one or two anterior minute, not verrucose; stamens 10, rarely indefinite, free; filaments glabrous; ovary sessile or shortly stipitate, cohering with or free in the receptacle; style filiform; stigma small, truncate or rounded; legume obliquely ovoid, obovoid, or reniform, rarely straight, coriaceous, turgid or slightly compressed, rugose, verrucose, rarely levigate, 2-valved; seeds exalbuminous. - Inarmed trees or shrubs; leaves paripinnate; leaflets 1 to 6 jugate, oblique, coriaceous; flowers usually reddish, small, in axillary or lateral clusters or short racemes; bracts ovoid, membranous, at first imbricate, later deciduous, rarely persistent; bracteoles wanting or, when present, membranous and colored.

\section{Cynometra portoricensis Krug \& Urb.}

(Urban, 270.)

Tree, 15 meters high; stipules wanting; leaflets 1-jugate, oblique, obovate-oblong, 1.5 to $3 \mathrm{~cm}$. long, 0.6 to $1.2 \mathrm{~cm}$. wide, entire, coriaceous, glabrous, shining; inflorescence axillary, rachis $5 \mathrm{~mm}$. long; legume semiorbicular, 2.5 to $3 \mathrm{~cm}$. long, 1.4 to 1.8 $\mathrm{cm}$. wide, crustaceous, sublevigate, brown.

Near Rincon, on wooded hills at Quebrada del Salto. Indigenous.

\section{STAHLIA Bello.}

Stahlia Bello, Anal. Soc. Esp. Hist. Nat. 102: 255. 1881.

Calyx with obconical receptacle and 5 free, subequal, obtuse segments; petals 5 , subequal, dorsally multiverrucose; stamens 10, free, filaments lanate; ovary sessile, free at the fundus of the receptacle; style filiform; stigma small, truncate; legume roundly ovoid, somewhat compressed, coriaceous, indehiscent (according to Bello very late dehiscent); seeds 2, exalbuminous; bracts membranous, not imbricate, caducous; bracteoles wanting.-- Unarmed trees; leaves paripinnate; leaflets paucijugate, oblique, thin, the lower surface glandular; flowers light yellow, not large, in axillary or terminal racemes.

This is the only endemic genus of Leguminosae in Porto Rico.

\section{Stahlia monosperma (Tul.) Urb.}

(Urban, 270.)

Handsome tree 5 to 20 meters high; leaves 24 to $30 \mathrm{~cm}$. long; leaflets 4 to 6 -jugate, ovate-oblong, 6 to $9 \mathrm{~cm}$. long, 2 to $4 \mathrm{~cm}$. wide, with subcordate or truncate base; inflorescence 10 to 20 -flowered, often $10 \mathrm{~cm}$. long; sepals 6 to $7 \mathrm{~mm}$. long, 4 to $5 \mathrm{~mm}$. wide; petals pale yellow, 10 to $11 \mathrm{~mm}$. long, 5.5 to $6 \mathrm{~mm}$. wide; anthers purple; legume 3.5 to $4.5 \mathrm{~cm}$. long, 2.5 to $3 \mathrm{~cm}$. wide, glabrous, red when mature.

Flowering from March to May, fruiting in August and September. 
In littoral woods near Rio Grande, at La Fistancia; near Ceiba; near Naguabo in the woods at Guyacan; near Guanica in the woods of La Boca, at Barinas and at La Plata.

The strong wood of this tree is much used in the manufacture of household furniture. Local names cóbana, polisandro.

\section{HYMENAEA L.}

Hymenaea L. Sp. PI. 2: 1192. 1753.

Courbari AdANs. Fam. 2: 317. 1763.

Tanroujou Juss. Gen. 351. 1789.

Courbaril Plum.; Endl, Gen. 1317. 1841.

Calyx with thick, campanulate receptacle, its segments 4 , imbricate; petals 5 , sessile, oblong or obovate, subequal or the posterior one often larger, glandular; stamens 10, free, glabrous; anthers glandular; ovary subsessile; style filiform; stigma terminal, small; legume obliquely obovate or oblong, thick and often almost terete, coriaceous or subligneous, indehiscent; seeds few, exalbuminous, without aril.Unarmed trees; leaves paripinnate; leaflets coriaceous, glandular-punctate; flowers usually large, white, in paniculate racemes; bracts and bracteoles ovate or orbicular, concave, caducous.

\section{Hymenaea courbaril L. $a$}

(Urban, 270.)

Tree 10 to 20 meters high; leaves bifoliate; leaflets leathery, polished, falcate-ovate or oblong, 6 to $10 \mathrm{~cm}$. long, 2.5 to $4 \mathrm{~cm}$. wide, shortly petiolate; flowers white, in many-flowered terminal cymes; calyx segments ovate, obtuse, leathery, $15 \mathrm{~mm}$. long; petals nearly equal, as long as the calyx segments; legume ligneous, thick, 7.5 to $10 \mathrm{~cm}$. long, 5 to $6 \mathrm{~cm}$. wide, indehiscent, filled with mealy pulp.

Near Bayamon; in the Sierra de Luquillo at Mavi; near Juncos in the woods of Mount Santo de Leon; near Maunabo, at Fmajagua; near Mayaguez; near Manati.Cuba (Grisebach), Jamaica, St. Thomas, St. Croix, St. John (Eggers), St. Bartholomew (Stockholm Herbarium), Antigua (Grisebach), Gaudeloupe, Dominica, Martinique, St. Lucia ((irisebach), St. Vincent, Bequia (Kew Bull. no. 81, p. 249), Mustique (do.), Brazil, Guiana, Colombia.

From the trunk of IIymenaca courbaril (locust tree, quapinole, jutahy, jatahy, or jatobà) a clear balsam drops to the ground, where it hardens. It is found in pieces weighing sometimes several pounds. This resin is known as American copal, resina copal, or courbaril, and is used by the Brazilian physicians and by the Indians as a medicament. The red wood is hard and heavy and is known in trade as courbaril wood. Among the Indians the sweetish pulp is a favorite food. They understand how to polish the resin inost beautifully, and they use it for all kinds of ornaments, especially for the well-known lip decorations, tembeta (of the Amazon near Paraná).

Local name, algurrobo.

\section{TAMARINDUS L.}

Tamarindus L. Sp. Pl. 1: 34. 1753.

Calyx with a narrowly turbinate receptacle and 4 strongly imbricated membranous segments; petals 3 ( 1 posterior, 2 lateral), oblong or obovate-oblong, subequal, shortly clawed; 2 anterior petals minute, setaceous or squammiform; fertile stamens 3 , the anterior connate nearly half their length, alternating with minute or rudimentary staminodia; ovary stipitate, multiovulate; style elongated; stigma terminal, truncate, capitate; legume oblong or oblong-lınear, thick, curved or nearly straight, compressed,

a For illustration of fruit see Cook and Collins, $p l$. 41, facing p. 164. 
indehiscent; epicarp thin, crustaceous; mesocarp pulpy; endocarp thick and fleshy, forming complete partitions between the seeds; seeds obovate-elliptical or roundish, compressed, with a thick, shining testa, each side marked with a large faintly defined areole; albumen none.-Unarmed trees; leaves paripinnate; leaflets multijugate, small, coriaceous, oblong, obtuse, reticulate, subsessile; stipules small, caducous; flowers yellowish or red-striped, in terminal racemes; bracts and bracteoles, ovateoblong, colored, caducous.

\section{Tamarindus indica $\mathrm{L}$.}

(Urban, 270.)

Tree 5 to 8 meters high, wholly glabrous or extremities at first thinly pubescent or puberulous, sometimes glaucescent; leaves 6 to $15 \mathrm{~cm}$. long; leaflets 1.5 to $2 \mathrm{~cm}$. long, 5 to $6 \mathrm{~mm}$. wide, oblong, 10 to 20 -jugate; flowers variegated, racemose; calyx segments $11 \mathrm{~mm}$. long, $4 \mathrm{~mm}$. wide; petals 10 to $12 \mathrm{~mm}$. long; legume 5 to $15 \mathrm{~cm}$. long, 1.5 to 2 $\mathrm{cm}$. wide, 1 to 4 -seeded.

Seemingly wild, also cultivated, in woods near Bayamon; near Aibonito at CariBlanco; near Peñuelas; near Mayaguez; near Rincon, in mountain forests around Hacienda Nieve.-Bahama (Hitchcock), Cuba (Richard), Jamaica, Haiti, St. Thomas, St. Croix, St. John (Eggers), St. Martin (Stockholm Herbarium), St. Bartholomew (do.), Guadeloupe, Martinique, St. Vincent, Bequia (Kew Bull. no. 81, p. 249), Mustique (do.), Margarita.

The tamarind, the only species of the genus, valued on account of the acid pulp of the fruit, would appear to be truly indigenous in tropical Africa. It is widely diffused either under cultivation or naturalized, through the Tropics of both the New and the old World. According to Grosourdy (cited by Cook and Collins, p. 248) the wood is of good weight and more than ordinarily hard. The texture is rather compact and the grain fine.

Local name, tamarindo

18. BAUHINIA L.

\section{Bauhinia L. Sp. P1. 1: 374. 1753.}

Flowers hermaphrodite, more rarely polygamous; calyx with a short turbinate or tubular receptacle, before anthesis undivided and closed at the top or contracted beneath the top and shortly 5 -lobed, at anthesis variously divided, vaginate or with 3 to 5 valvate, rarely imbricate, segments; petals 5 , usually subequal, more rarely the uppermost differing in form from the others, imbricate in estivation; stamens 10 , all fertile, with free or more or less connate filaments and dorsifixed anthers, or reduced to, 1 to 9 staminodia, or entirely wanting; ovary sessile or stipitate, rarely glandular below, 2 to many-ovulate; style filiform, often very short, usually long; stigma terminal, dilated and obliquely peltate or inconspicuous; legume oblong or linear, straight, oblique, or curved, membranous, corlaceous, or almost fleshy, continuous or pulpy between the seeds, seldom septate, indehiscent or 2 -valved; seeds compressed, albuminous, subglobular or ovate; seed coat thin or hard; root short and straight, rarely oblique or slightly curved.-Trees or erect or scandent shrubs, unarmed, or with interstipulary prickles, and with round or unequally compressed or broadened and flat trunk and often with branches that are transformed into tendrils; leaves simple, sometimes entire, sometimes 2-lobed or parted, more rarely 2 -foliolate; stipules varying, caducous; flowers 2 or 3 together on leaf-opposed or terminal peduncles or collected in simple or compound corymbs, racemes, or panicles, white or rose to purple and yellow.

The three species of Bauhinia found in Porto Rico are trees or shrubs, with 2-lobed leaves. The calyx is closed at the top or contracted beneath the top and shortly 5-lobed, and at anthesis is vaginate. In the section Pauletia, embracing two of the 
species, there are 5 to 10 fertile stamens. In Casparia, containing the third, there is but 1 fertile stamen. The legume is straight, linear, coriaceous, continuous, 2-valved. Both axillary and terminal racemes occur.

KEY TO THE SPECIES.

Fertile stamens 10 or 5 . (Section Pauletia.)

Petals narrow, linear; stamens 5.

Petals obovate or obcordate; stamens 10.

Fertile stamens 1, the rest without anthers. (Section Casparia.)

\section{Bauhinia pauletia Pers.}

1. Bauhinia pauletia.

2. Bauhinia tomentosa.

3. Bauhinia kappleri.

(Urban, 271.)

Erect or scandent shrubs 3 meters high, armed, leaves suborbicular or quadrate, 5 to $8 \mathrm{~cm}$. long and wide, glabrous above, pubescent beneath; petiole 1 to $2.5 \mathrm{~cm}$. long; calyx lobes 10 to $14 \mathrm{~cm}$. long; petals narrowly linear, 5 to $8 \mathrm{~cm}$. long, 1 to $1.5 \mathrm{~mm}$. wide; legume 15 to $25 \mathrm{~cm}$. long, 1 to $1.5 \mathrm{~cm}$. wide, subtomentose; flowering and fruiting in January and February.

In the copse near Mayaguez; near Cabo Rojo; near Guanica, between La Plata and Sabana Grande near Limon.-Mexico, Nicaragua, Panama, Venezuela. West Indies, Trinidad, in shady woods near Arima.

Local names, mariposa, araña gato.

\section{Bauhinia tomentosa L.}

(Urban, 271.)

Shrub 1 to 4 meters high; leaves cordate, usually 7 -nerved, membranous, $3.75 \mathrm{~cm}$. to $7.50 \mathrm{~cm}$. in diameter, bilobed to one-half or one-third its length, glabrous above, paler or somewhat glaucous, minutely tomentose-pubescent or glabrate beneath, the lobes rounded above and below; calyx limb spathaceous; petals obovate or obcordate, 2.50 to $6.25 \mathrm{~cm}$. long, subsessile or shortly clawed, venation divergent, not prominent, pale yellow, posterior one pale purple, with a reddish, nearly black, spot at the base.

Cultivated and also seemingly wild, near Fajardo on waysides; near Mayaguez.Jamaica, Haiti, St. Thomas, St. Croix, Guadeloupe, Martinique, Trinidad. Native country, southeastern Asia, tropical Africa.

\section{Bauhinia kappleri Sagot. $a$}

(Urban, 271.)

Tree or shrub 10 to 15 meters high; leaves ovate or orbicular, 8 to 12 , sometimes 18 $\mathrm{cm}$. long and wide, truncate or subcordate at the base, 11 to 13-nerved, unarmed; petioles 3 to $6 \mathrm{~cm}$. long; calyx $2 \mathrm{~cm}$. long; petals obovate, $5 \mathrm{~cm}$. long, 2 to $2.5 \mathrm{~cm}$. wide; flowers very large, showy, whitish, rose color, or yellow, with purple lines in lax racemes.

Cultivated and seemingly spontaneous, near Bayamon; near Fajardo; near Naguabo; around Hacienda Oriente; near Adjuntas at Saltillo; near Peñuelas at La Cueva; near Cabo Rojo on Mount Buena Vista; near Mayaguez; near Manati on calcareous mountains; near Rio Arriba around dwellings.-Cuba, Jamaica (Hitchcock), Haiti, St. Thomas, St. Croix, St. Kitts, Guadeloupe, Martinique, St. Vincent, Guiana. Native country, southeastern Asia?

Local names, flamboyán blanco, varietal, seplina.

a For illustration see Cook and Collins, pl. 19, facing p. 90. 
19. CASSIA L.

Cassia L. Sp. Pl. 1: 376.1753.

Senna Tourn.; MrLe. Gard. Dict. ed. 8. 1768.

Bactyrilobium Willd. Enum. 439. 1809.

Chamaefistula G. Don, Hist. Dichl. Pl. 2: 451. 1832.

Calyx with a very short receptacle and 5 imbricate segments; petals 5 , imbricate, spreading, subequal or the anterior larger; stamens sometimes 10 , all perfect and subequal, or the anterior shorter, or the three anterior very small, abortive, or wanting, sometimes only 5; filaments very short or elongated, rarely nodose, incrassate, or dilated in the middle; anthers uniform, or those of the anterior stamens larger, their cells dehiscing in terminal pores or in short lateral slits; ovary sessile or stipitate, free in the fundus of the receptacle, often arcuate, multiovulate, style short or elongated; stigma terminal, small, truncate, rarely ciliate or turgid; legume terete, flat, compressed, quadrangular, or alate, membranous, coriaceous, or ligneous, indehiscent, or sometimes 2 -valved, with or without transverse internal septa, seldom with pulp; seeds albuminous, flattened at right angles to or parallel with the valves, rarely rhomboid-subterete, transverse, rarely longitudinally disposed in the legume; cotyledons ovate or oblong, plane, sometimes sinuous. Trees, shrubs, or herbs; leaves paripinnate, rarely wanting or reduced to small squamae; stipules various; glands of the common petiole sessile or stipitate, verrucose, hypocrateriform, scutellate, near the base or interpetiolular; flowers yellow or red, in axillary or terminal racemes, corymbs, or fascicles; occasionally solitary or geminate in the axils.

KEY TO THE SPECIES.

Perfect stamens usually 7 , the 3 anterior with long curved filaments, often dilated beyond the middle, and ovate or elliptical anthers, not exceeding 4 to $6 \mathrm{~mm}$. in length, dehiscing longitudinally; the 4 to 6 intermediate filaments much shorter, erect, dehiscing by means of pores; the remaining anthers 3.2 , or 1 , much smaller, often sterile; legume elongated, pendulous, terete or slightly compressed, indehiscent or rarely dehiscent, divided by transverse partitions into numerous 1-seeded cavities; seeds horizontal, flattened at right angles to the axis of the legume. (Subgenus and Section Fistula DC.)

Leaflets 4 to 8 -jugate, ovate or ovate-lanceolate, 7 to 12.5 $\mathrm{cm}$. long, 4 to $7 \mathrm{~cm}$. wide, subacuminate, glabrous; petiolules rather long; legume round, 30 to $60 \mathrm{~cm}$. long, levigate.

Leaflets 10 to 20 -jugate, oblong, 3.5 to $5.5 \mathrm{~cm}$. long, 2.5 1. C. fistula. $\mathrm{cm}$. wide, obtuse at both ends, both surfaes pubescent; petiolules short; legume compressed-cylindrical, 45 to $60 \mathrm{~cm}$. long, venose-rugose.

Perfect stamens usually 7 , the 2 or 3 anterior somewhat longer, the anthers linear curved, 6.5 to $13 \mathrm{~mm}$. long, opening at the top by 1 or 2 pores, rarely dehiscing longitudinally; staminodia usually 3 ; valves not elastic, the legume rarely indehiscent. (Subgenus Senna Benth.)

Legumes round, turgid or slightly compressed; seeds transverse, horizontal; leaves interglandular or eglandular. (Section Chamaefistula DC.)

Leaflets 2-jugate.

3. C. quinquangulata. 
Leaflets 3 to 5 -jugate.

Leaflets small, 2 to $3.5 \mathrm{~cm}$. long, obtuse at both ends.

Leaflets usually 3 or 4 -jugate, obovate or oval-roundish, rounded at the top, glands between the leaves; racemes few-flowered; pedicels 3 to $6 \mathrm{~mm}$. long; legume coriaceous, dehiscent along the sutures.

Leaflets usually 5-jugate, oval or elliptical, rounded at the top, a gland between the lower leaves; racemes long and manyflowered; pedicels 2 to $3 \mathrm{~cm}$. long.

Leaflets large, ovate-oblong or ovate-lanceolate, acuminate, 5 to $8 \mathrm{~cm}$. long; petiole with oblong glands between the leaflets; legume terete.

Legume flattened-compressed, membranous, bivalved, convex; seeds compressed parallel to the dissepiments; petiole with obtuse glands near the base. (Section Oлсоцовіuм Vog.)

Leaflets 4 or 5-jugate, ovate or elliptic lanceolate, 2.5 to $5 \mathrm{~cm}$. long.

Legume compressed-tetragonal, linear; seeds compressed parallel to the valves, their larger diameter likewise parallel to the valves. (Section Prososperma Vog.)

Leaflets 2 or 3-jugate, obovate or obovate-oblong, 1.5 to $5 \mathrm{~cm}$. long; legume 10 to $20 \mathrm{~cm}$. long, 4 to $6 \mathrm{~mm}$. wide.

Legume flat-compressed, bivalved; seeds compressed parallel to the valves, with their longer diameter transverse to them. (Section Chamaesenna DC.)

Legume winged with a broad longitudinal wing on each valve; leaves 30 to $60 \mathrm{~cm}$. long; leaflets 9 to 12 -jugate, oblong, truncate at the subsessile base, 7.5 to $17.5 \mathrm{~cm}$. long; petiole 3-angular, eglandular. Legume not winged.

Leaves very small; leaflets 5 to 15 -jugate, obovate-oblong, ciliate on the margins, otherwise glabrous; leaves fasciculate at the nodes; legumes narrow.

Leaves much larger, pilose; leaflets 3 to 5 -jugate, rarely 2 -jugate, broadly oval-oblong, very obtuse, upper surface pubescent, lower surface tomentose, eglandular; legume coriaceous, linear, straight, glabrous, tumid at the margins.

Stamens 10 or fewer, all perfect, similar and but slightly unequal (rarely 2 or 3 abortive); anthers linear; pedicels solitary, in pairs or fascicles, axillary or superaxillary; common peduncle very short; legumes flat, linear, elastic, 2-valved. (Subgenus Lasiorhegia Vog. Section Chamaecrista DC.)

Leaflets 1-jugate, oblique, semiorbicular or semiobovate, flabellate-nerved: petiole glandular; peduncle oneflowered; legume hairy with adpressed down.
4. C. bicapsularis.

5. C. stahlii.

6. C. laevigata.

7. C. occidentalis.

8. C. tora.

9. C. alata.

10. C. polyphylla.

11. C. emarginata.

12. C. diphylla. 
Leaflets multijugate, very small.

Leaves subcoriaceous; leaflets 6 or 7 , rarely 5 to 11 jugate, oblique, oblong-linear, rounded at the top, 8 to $15 \mathrm{~mm}$. long, 2 to $4 \mathrm{~mm}$. wide, glandular; peduncle 1 or 2-flowered; legume linear, hairy.

13. C. portoricensis.

Leaves membranous.

Glands stipitate; leaves obtuse or subacute; costa usually in the middle.

Leaves large, $7.5 \mathrm{~cm}$. long; leaflets $1.1 \mathrm{~cm}$. long, $2 \mathrm{~mm}$. wide; common petiole and legume thinly clothed with white hairs; legume $4.5 \mathrm{~cm}$. long, $5 \mathrm{~mm}$. wide.

Leaves small, $2.5 \mathrm{~cm}$. long; leaflets $5 \mathrm{~mm}$. long, $1 \mathrm{~mm}$. wide; common petiole and legume glabrous; legume $2.5 \mathrm{~cm}$. long, 3 mm. wide.

Glands sessile or shortly stipitate; leaves narrower, mostly acute; costa more eccentric.

14. C. glandulosa.

\section{Cassia fistula L.}

\section{(Urban, 272.}

Tree 7 to 20 meters high: flowers in lax drooping racemes, yellow, large: pedicels long: calyx segments oval or oval-oblong, $1 \mathrm{~cm}$. long, obtuse; petals ovate, 2 to $2.5 \mathrm{~cm}$. long; legume pendulous. Flowering in June, fruiting in January.

Cultivated and seemingly wild near Bayamon; in the Sierra de Luquillo, on the lower slopes of Mount Jimenez near dwellings; near Mayaguez, at Algarrobo.-Cuba (Grisebach), Jamaica, Haiti, St. Croix (Eggers), St. Bartholomew (Euphrasén), Gaudeloupe, Martinique, St. Vincent, Bequia (Kew Bull. no. 81, p. 248), Trinidad, Margarita. Tropical Asia, frequently planted, but also truly indigenous; in tropical Atrica cultivated or escaped from cultivation and possibly indigenous; in America only where planted.

Cassia fistula and C. grandis are closely related. Both are noticeable on account of their long simple racemes. C. fistula differs from other Porto Rican Cassia species in its very large leaves and in its long pendulous legumes. The latter are cylindrical in form and contain a dark brown, soit, agreeable-tasting pulp that has a slightly purgative action. This fruit, called "manna," is considered a delicacy, especially by children. The bark furnishes a black dye, and is employed in tanning leather, while the wood is valuable for many purposes.

Local name, cañafistula.

2. Cassia grandis L. f.

(Urian, 272.)

Tree 15 to 20 meters high; flowers in drooping, axillary rusty-pubescent racemes; calyx segments rather wide, 6 to $8.5 \mathrm{~mm}$. long, obtuse; petals suborbicular, $1 \mathrm{~cm}$. in diameter; legume 45 to $60 \mathrm{~cm}$. long, transversely rugulose.

Indigenous and cultivated, near Peñuelas at Tallaboa Alta; near Yauco, on declivities on the banks of the Duey River at Mount Rodadero; near Mayaguez; near lega Baja.-Cuba (Richard), Jamaica (Bentham), Haiti, St. Thomas (Eggers), St.Croix (do.), Guadeloupe. Central America, Ecuador, New Grenada, Surinam, San Domingo, Jamaica, and perhaps North Brazil.

This differs from C. fistula, the only other species in Porto Rico belonging to the subgenus and section Fistula DC., in the rusty pubescence of its racemes, and in its much smaller, multijugate leaflets. 
The natives make from the leaves, seeds, and roots of $C$. grandis and C. occidentalis various medicaments. Grosourdy (cited by Cook and Collins, p. 108) says that the wood of this tree is handsome, strong, and very resistant, of ordinary weight and hardness, fibrous in texture and fine-grained.

Local name, cañafistula cimarrona.

\section{Cassia quinquangulata $\mathbf{L}$.}

(Trban, 272.)

Shrub 2.5 to 3 meters high or a small tree about 10 meters high; branches angular; leaflets 2-jugate, obliquely ovate, shortly and obtusely acuminate, 7.5 to $10 \mathrm{~cm}$. long, the lower sometimes smaller, shining above, yellow-pubescent beneath, the glands slender, between each pair of leaflets; flowers in short racemes, usually arranged in a terminal panicle; sepals ovate, petals 1.2 to $1.6 \mathrm{~cm}$. long.

Flowers from September to December.

Near Bayamon in a copse; Sierra de Naguabo, on slopes along the Rio Blanco; near Juncos, on Mount Florida; near Hato Grande, on Mount Gregorio; between Gurabo and Caguas; near Aibonito, at La Lima; near Maricao, in mountain forests.-St. Thomas, St. Kitts. Guiana, Brazil.

\section{Cassia bicapsularis $\mathrm{L}$.}

(Urban, 273.)

Shrub 2 to 3.5 meters high; leaves 6 to $9 \mathrm{~cm}$. long; leaflets 3 to $4 \mathrm{~cm}$. long, 1 to $2 \mathrm{~cm}$. wide; sepals membranous, obtuse, 8 to $11 \mathrm{~mm}$. long; petals yellow, 1.7 to $1.9 \mathrm{~cm}$. long; legume erect or somewhat curved, 9 to $15 \mathrm{~cm}$. long, 1 to $1.5 \mathrm{~cm}$. wide.

Near Fajardo in thickets on the coast; near Peñuelas; near Yauco, on Mount Duey; on calcareous mountains near Cabo Rojo; near Mayaguez.-Bermuda (introduced, Hemsley), Bahama (Grisebach), Cuba (Richard), Jamaica, Haiti, St. Thomas, St. Croix, St. John (Eggers), St. Bartholomew (Stockholm Herbarium), Antigua (Grisebach), Guadeloupe, Dominica (Grisebach), Martinique, St. Vincent, Mustique (Kew Bull. no. 81, p. 248), Barbados, Grenada, Curaçao. Tropical and subtropical South America, very common, extending from south Brazil to Central America; frequently sent also in collections from tropical Asia, but there only in cultivation. Madeira.

Local names, sen del pais, hoja de sen.

\section{Cassia stahlii Urb.}

$$
\text { (Trban, 273.) }
$$

Shrub 2 to 4 meters high; leaflets 5 -jugate, the upper oval or elliptical, 2.5 to $3 \mathrm{~cm}$. long, 1 to $1.5 \mathrm{~cm}$. wide, the lower orbicular-oval, $1 \mathrm{~cm}$. long; glands of the common petiole interpetiolular, oblong-linear; racemes long and many-flowered; flowers purple-veined; sepals 6 to $7 \mathrm{~mm}$. long; petals 10 to $13 \mathrm{~mm}$. long; legume erect, 12 to $15 \mathrm{~cm}$. long, $1.5 \mathrm{~cm}$. wide, linear.

In mountain forests between Guayama and Guamani; near Cayey, on the river Morillos; near Aibonito, at La Lima. Indigenous.

C. stahlii resembles in habit the closely related species $C$. bicapsularis, but differs from it in its longer inflorescence, much longer pedicels, and 5-jugate leaflets.

\section{Cassia laevigata Willd.}

$$
\text { (Urban, 273.) }
$$

Shrub 2 to 3 meters high, glabrous; leaflets 3 or 4 -jugate, ovate-oblong to lanceolate, 5 to $8 \mathrm{~cm}$. long, 2 to $3 \mathrm{~cm}$. wide; common petiole 10 to $12.5 \mathrm{~cm}$. long, channelled, with oblong or eylindrical interpetiolular glands; basal glands none; flewers in axil- 
lary or terminal racemes; calyx $6 \mathrm{~mm}$. long, petals $1.6 \mathrm{~cm}$. long; legumes erect, thinly coriaceous or chartaceous, obtuse, apiculate, 7.5 to $8 \mathrm{~cm}$. long, $1.2 \mathrm{~cm}$. wide, tardily dehiscent into 2 valves; seeds horizontal, shining.

Near Juncos on Mount Florida; near Adjuntas, in the river valley at La Galsa and on Mount Cienega at La Lucia; near Utuado; near Maricao, on Mount Alegrillo.Jamaica, Martinique (cultivated). Tropical and subtropical America, chiefly in waste and cultivated places. Brazil, Guiana, Colombia, Central America, Mexico, and also in similar situations in tropical Asia, west Africa, and Australia, probably in most places introduced.

Like other common weeds of cultivation, this is a variable species, but it is always readily recognized by its acute or acuminate glabrous leaflets, with glands between all the pairs, or all but the terminal. Cassia laevigata and C. chamacerista, in their respective habitats, are used as a substitute for the genuine senna leaves, folia sennae.

Local names, sen del pais, yerba hedionda macho.

\section{Cassia occidentalis L.}

(Urban, 273.)

Stem firmly herbaceous or woody below, annual of 2 or 3 years' duration, erect, a few feet in height often forming dense bushy masses; leaflets 4 or 5 -jugate, ovate or elliptic-lanceolate, 5 to $7 \mathrm{~cm}$. long, 2 to $2.5 \mathrm{~cm}$. wide; common petiole without interpetiolular glands, but with a short obtuse gland near the base, black when dry; flowers in short few-flowered axillary racemes or fascicles; sepals obtuse, 6 to $8.5 \mathrm{~mm}$. long, glabrous; petals obtuse, $1.5 \mathrm{~cm}$. long; legume linear, compressed, 7 to $11 \mathrm{~cm}$. long, 6 to $8 \mathrm{~mm}$. wide, 2-valved, rather coriaceous, margined with straight sutures.

Near Bayamon; near Maricao, in pastures; near Mayaguez.-Bermuda (introduced, Hemsley), South Florida (Chapman), Bahama (Hitchcock), Cuba, Jamaica, Cayman (Hitchcock), Haiti, St. Thomas, St. Croix, St. John (Eggers), St. Martin (Stockholm Herbarium), St. Bartholomew, Martinique, St. Vincent, Bequia (Kew Bull. no. 81, p. 249), Barbados, Grenada, Tobago, Trinidad (Grisebach), Margarita. Tropical America, Asia, and Africa; very abundant in waste and cultivated places. Probably of American origin; not yet received from Australia.

The foliage and inflorescence of this species are generally nearly those of $C$. laevigata, except as to the gland, which is always below the lower pair of leaflets, and usually very near the base of the petiole, not between the leaflets.

The root of Cassia occidcntalis, cortex fedegozo, is a valued remedy for intermittent fever, and by the American Indians is thought to be an antidote against various poisons. Seeds and leaves are both used medicinally. In the West Indies the negroes apply the leaves smeared with grease in cutaneous diseases of men and of animals. The roasted seeds, known as Sudan coffee, are used as a substitute for coffee.

Local name, hedionda.

Cassia ligustrina L. (C. occidentalis variety glabra Stahl) is cultivated in gardens near Bayamon and Manati. It is native in Bahama, Cuba, Jamaica, and Haiti.

\section{Cassia tora L.}

(Urban, 274.)

Stem annual, erect or ascending 0.75 to 1 meter high; leaflets 2 or 3 -jugate; obovate or obovate-oblong, varying from 1.5 to 3.5 or $5 \mathrm{~cm}$. in length; common petiole with conspicuous narrow-cylindrical glands between at least the lower pinnae; flowers usually in pairs or solitary, axillary, with or without a short common peduncle; sepals 6 to $8 \mathrm{~mm}$. long; petals 13 to $17.5 \mathrm{~mm}$. long; legumes elongate, curved, narrow-linear, 10 to $20 \mathrm{~cm}$. long, 4 to $6 \mathrm{~mm}$. wide, dehiscent; seeds arranged lengthwise.

25734 - voL 10, rT $4-07-3$ 
Near Bayamon; near Cabo Rojo around Hacienda Carmelita; near Mayaguez at the fortress.-Bahama (Hitcheock), Cuba (Grisebach), Jamaica, Haiti, St. Thomas, St. Croix (Eggers), Guadeloupe, Martinique, St. Vincent, Bequia (Kew Bull. no. 81, p. 249), Barbados, Grenada, Tobago, Trinidad. Tropical and subtropical America, Asia, Africa, and Australia, generally common in cultivated and waste places; in the United States extending as far north as Virginia, Indiana, and Arkansas.

This plant is striking on account of its narrow linear curved legumes, which are oblong-quadrate in section. The young leaves, in spite of their disagreeable odor, are used as a vegetable, while both the leaves and seeds constitute a valuable remedy in skin diseases. The seeds when roasted and ground are said to yield a decoction which is reported to be in every respect as good as coffee.

Local name, dormidera.

\section{Cassia alata L, $a$}

(Urban, 275.)

An erect glabrous or subglabrous shrub, 2 to 4 meters high; leaves 30 to 60 or 90 $\mathrm{cm}$. long, rachis acutely margined above when dry, glandular, with a prominent transverse ridge connecting the opposite leaflets; leaflets 9 to 12 -jugate, upper larger leaflets obovate-elliptical, 7.5 to $17.5 \mathrm{~cm}$. long, firmly membranous; flowers light yellow, in axillary or terminal racemes; sepals $1 \mathrm{~cm}$. long; petals obovate, 1.5 to $1.9 \mathrm{~cm}$. long, the claw 2 to $3 \mathrm{~mm}$. long; legume 2-valved, coriaceous, 12.5 to $15 \mathrm{~cm}$. long, 1 to $2 \mathrm{~cm}$. wide, each valve with a very prominent crenate longitudinal wing extending its entire length and incurved toward the ventral suture.

Wild and cultivated, near Bayamon, in gardens; near Coamo, in the valley of El Fuerte River; near Maricao, on the bank of the river near Mayaguez.—Cuba, Jamaica, Haiti, St. Thomas (Grisebach), St. John, St. Croix (Eggers), Guadeloupe, Martinique, St. Vincent, Grenada. Widely spread in the Tropics of both hemispheres, though probably indigenous only in America.

This is the only Cassia species in Porto Rico in which the legume is winged. The large leaflets connected by a transverse ridge make it easily recognized. From the leaves, especially in Java and South America, is made a remedy used in skin diseases and they were formerly officinal under the name of folia cassiae herpetica.

Local names, talantala, talantro.

\section{Cassia polyphylla Jacq.}

(Urban, 274.)

Shrub 2 to 4 meters high or tree 15 meters high; leaflets 5 to 15 -jugate (often 10 to 12 jugate), minute, 4.5 to $6.5 \mathrm{~mm}$. long, 3 to $4 \mathrm{~mm}$. wide: flowers solitary in the axils of the leaves; sepals $7 \mathrm{~mm}$. long; petals $1.7 \mathrm{~cm}$. long; pedicels 1.5 to $2 \mathrm{~cm}$. long, slender; legume $15 \mathrm{~cm}$. long.

Near Guayama; near Coamo, at San Ildefonso and on the declivities of Mount Santana; along roads between Aibonito and Coamo; near Ponce, at Peñon; near Juana Diaz, at Escalabrado; near Guanica, in littoral thickets; near Salinas de Cabo Rojo, in the seashore woods of Mount Juliana.-Haiti, St. Thomas, St. Croix. Tropical America.

This differs from all the other Porto Rico Cassia species in its small fasciculate leaves and its minute leaflets.

\section{Cassia emarginata L.}

(Urban, 274.)

Shrub 3 to 10 or tree 15 meters high; leaflets 2 to $6 \mathrm{~cm}$. long, 1.5 to $3 \mathrm{~cm}$. wide; flowers golden yellow, in racemes which are solitary or fasciculate in the axils of the

$a$ For illustration see Cook and Collins, pl. 39 , facing p. 159 (as Herpetica alata). 
leaves; sepals 4 to $6.5 \mathrm{~mm}$. long; petals 6.5 to $11 \mathrm{~mm}$. wide; legume 17 to $30 \mathrm{~cm}$. long, 0.6 to $1 \mathrm{~cm}$. wide.

Near Coamo, in thickets between Serillos and Salinas and toward Baños and in woods on Mount San Ildefonso; between Salinas and St. Isabel.-Cuba, Jamaica, Haiti, Guadeloupe, St. Vincent (Grisebach), Margarita. Colombia, Central America.

\section{Cassia diphylla L. $a$}

(Urban, 275.)

Annual, suffrutescent, glabrous, 0.33 to 1 meter high; leaflets 1.5 to $2.5 \mathrm{~cm}$. long, 0.8 to $1.25 \mathrm{~cm}$. wide; stipules large, very acute, scarious; sepals 6.5 to $13 \mathrm{~mm}$. long; petals shorter than the sepals; legume 3 to $5 \mathrm{~cm}$. long, $6 \mathrm{~mm}$. wide; seeds oblong, oblique to the margins of the legume.

Near Bayamon, on declivities toward Toa Baja; near Santurce; near Humacao, on grassy declivities at Buenavista; near Salinas de Cabo Rojo, on the seashore and on Mount Juliana; near Rincon, in rocky places on the mountains; near Aguada, in fields at Piedra Blanea; near Manati, around the lagoon of Tortuguero in sandy districts near Campo.-Cuba, Haiti, St. Kitts (Grisebach), St. Vincent. Tropical America: from Brazil to Central America and Mexico.

Cassia diphylla is easily recognized, as it is the only Porto Rican Cassia species with but one pair of leaflets.

Local names, hediondilla, zarzabacoa.

\section{Cassia portoricensis Urb.b}

(Urban, 275.)

Small shrub, 0.25 to 0.60 meters high; leaflets 8 to $15 \mathrm{~mm}$. long, 2 to $4 \mathrm{~mm}$. wide; stipules lanceolate, acuminate; inflorescence 1 or 2 -flowered; sepals lanceolate or ovatelanceolate, 6.5 to $5 \mathrm{~mm}$. long; petals obovate or orbicular-obovate, 12 to $15 \mathrm{~mm}$. long, short-clawed; stamens 8 .

\section{Cassia portoricensis callosa Uro.}

(Urban, 275.)

Leaflets on the margin callose-incrassate, glabrous or subpilose; inflorescence usually 2-flowered.

Near Guayanilla, on calcareous mountains near Peñon; near Mayaguez.

Local name, retama.

\section{Cassia portoricensis granulata Urb.}

(Urban, 275.)

Shrub 0.3 to 1 meter high; leaflets not callose on the margin, pilose; inflorescence 1-flowered.

Near Ponce, on the harbor; near Salinas de Cabo Rojo, in forests of the seashore; near Guanica, in thickets on Mount El Maniel and in salty places on the seashore. Indigenous.

Local name, escobilla.

This species is distinguished from the related species by its subcoriaceous, oblique leaves. 


\title{
14. Cassia glandulosa L.a
}

(Urban, 276.)

A herbaceous or suffrutescent plant 0.5 to 1.5 meters high; leaves 5 to $8 \mathrm{~cm}$. long; leaflets oblong-linear, membranous; peduncle 1 to 3 -flowered; sepals $1 \mathrm{~cm}$. long; petals 1.5 to $2 \mathrm{~cm}$. long, yellow; stamens red; legume 3 to $6 \mathrm{~cm}$. long, 5 to $6 \mathrm{~mm}$. wide.

In sandy districts near Bayamon; Sierra de Naguabo, on the rocks on Mount Piedra Palada and on the banks of the Rio Blanco; between Aibonito and Algarrobo, along roads; between $\Lambda$ ibonito and Coamo, on precipices; near Utuado, on declivities at Pellejas and at Mameyes and in rocky districts at Los Angeles; near Sabana Grande, on the banks of the River Estero; near Arecibo.-Cuba (Richard), Jamaica, St. Croix, St. Martin (Stockholm Herbarium), Guadeloupe, Dominica, Martinique, St. Vincent, Bequia (Kew Bull. no. 81, p. 248), Barbados, Grenada, Trinidad (Grisebach).Tropical South America: Brazil, Guiana, Colombia.

Cassia glandulosa has often (as by Linnaeus himself) been confounded with other species, but it can be distinguished from Cassia chamaecrista in that its petiole bears a stipitate gland between the lowest pair of leaflets (and sometimes several below the upper pairs) and in that the pairs of leaflets are usually much more numerous. Cassia chamacerista has sessile depressed glands.

Local name, tamarindillo, hediondilla.

\section{Cassia mirabilis (Poll.) Urb.}

(Urban, 276.)

Stem suffrutescent, glabrous; leaves pinnate, $2 \mathrm{~cm}$. long; petiole $1.5 \mathrm{~cm}$. long, with two stipitate glands; leaflets 10 to 17 -jugate, $5 \mathrm{~mm}$. long, $1 \mathrm{~mm}$. wide, oblong, rounded at both ends, papyraceous, glabrous on both sides, shortly petiolulate, mucronate; stipules lanceolate, acuminate, $3 \mathrm{~mm}$. long; flowers yellow; legumes 2 to $2.5 \mathrm{~cm}$. long, $3 \mathrm{~mm}$. wide, brown, glabrous, papyraceous, apiculate.

Near Manati, in sandy soil on the edge of Tortuguero Lagoon at Campo Alegre; between Manati and Vega Baja in sandy soil; near Dorado, in the meadows of the coast.

\section{Cassia nictitans $\mathrm{L}$.}

\author{
(Trban, 276.)
}

Annual, herbaceous or suffrutescent, pubescent, with curved hairs, or glabrescent; leaflets 12 to 25 -(rarely 5-) jugate, 0.4 to $1 \mathrm{~cm}$. long, oblong-linear, mucronulate, slightly oblique at the base, penninerved, striate with veins; petiole bearing a stipitate gland below the lowest pair; stipules exceeding the insertion point of the gland, acuminate from a lanceolate, oblique base; peduncle 1-(to 3-) flowered, much exceeded by the leaves; stamens 5 to 7 (or even 10 ) ; legume bearing scattered curved hairs; petals 0.6 to $0.8 \mathrm{~cm}$. long.- Variable in the petiolar glands, which are long-stipitate or subsessile.

Near Bayamon; near Santurce; near Juncos, on Mount Santo de Leon; near Maunabo, at Punta de la Tuna; near Aibonito, on precipices toward Coamo; near Coamo, in meadows between Serillos and Salinas; between Peñelas and Tallaboa Alta, on the roadside; near Sabana Grande, on the bank of the Estero River; near Guanica, in thickets on the seashore at Caño Fordo; near Mayaguez; near Maricao, in pastures; near Rincon, in the mountains at Calvache--Bahama, Cuba, Jamaica, Haiti. St. Thomas, St. Kitts, Guadeloupe, Martinique, St. Vincent, Margarita, ('uraça, Mexico, subtropical and temperate North America. 


\section{KRAMERIA Loefl.}

Krameria LoErL. Iter Hisp. 195. 1758.

Calyx with 4 or 5 subequal, imbricate, more or less corollaceous segments, the outer one somewhat larger than the others; petals 4 or 5 , narrower than the calyx segments, the upper ones subequal, long-clawed, sometimes free, sometimes connate, the middle one often folded, the 2 lower ones reduced to thick, short, fleshy scales; stamens 3 or 4 , hypogynous, the anthers basifixed, opening by an oblique introrse pore; ovary sessile with 2 collateral, hanging, anatropous seeds; style cylindrical, pointed; legume globose or somewhat compressed, aculeate or weakly spinous, indehiscent; seeds exalbuminous. - Shrubs or herbs, often decumbent and silky-tomentose; leaves simple or rarely digitate (leaflets 3 ); flowers purple, axillary, sometimes in leafy racemes; bracts 2, at or above the middle of the peduncle; filaments free, or connate half their length.

\section{Krameria ixina $\mathbf{L}$.}

(Urban, 277.)

Plant 0.5 to 1 meter high; stem erect, branched, woody below, villous-pubescent; leaves elliptical-lanceolate, mucronate; flowers racemose, purple or dark purple; pedicels short, bibracteolate about the middle; sepals 4, pubescent externally; posterior petals connected at the base; stamens 4 ; spines of pericarp glochidiate.

Between Ponce and Guayanilla, on calcareous rocks of the coast; near Ponce, on the harbor and at Peñon; near Guanica, in littoral thickets at Salinas and on the declivities at Punta de los Pescadores; near Cabo Rojo, in forests near the seashore.-Haiti, St. Thomas, Antigua (Grisebach), Curaçao (Vahl), Colombia.

\section{PARKINSONIA L.}

\section{Parkinsonia L. Sp. Pl. 1:375. 1753.}

Calyx with a short receptacle and 5 subequal, membranous, slightly imbricate segments; petals 5 , nearly equal, the posterior one the widest; stamens 10 , their filaments villous at the base; ovary free, in the fundus of the receptacle, substipitate, multiovulate; style filiform; stigma small, terminal; legume narrowly linear, narrowed to each end, usually constricted between the subdistant seeds, scarcely or not at all dehiscent; valves thinly coriaceous, longitudinally reticulate-striate; seeds oblong, longitudinally disposed, albuminous.- Trees or shrubs with thorny stipules; leaves bipinnate; common petiole very short, spine-pointed; pinnae 2 to 4 , with the rachis much elongated, flattened, bearing numerous, opposite or scattered, very small leaflets, which are occasionally abortive; flowers yellow, in lax axillary racemes; bracts small, caducous; bracteoles wanting.

\section{Parkinsonia aculeata L.}

\section{(Urban, 277.)}

Small trees or shrubs; common petiole only 1 to $2 \mathrm{~mm}$. long: pinnae 1 or 2 -jugate; secondary petioles winged, linear, acuminate, 16 to $36 \mathrm{~cm}$. long; leaflets minute, oblong or obovate, 4 to $5 \mathrm{~mm}$. long, 1 to $2 \mathrm{~mm}$. wide, blunt, the uppermost (or many) abortive; flowers yellow, in lax axillary racemes, 9 to $16 \mathrm{~cm}$. long; calyx $7 \mathrm{~mm}$. high; corolla suborbicular, $1 \mathrm{~cm}$. in cliameter; legume 8 to $9 \mathrm{~cm}$. long, $1 \mathrm{~cm}$. wide, constricted between the seeds.

Near Fajardo on the seashore between Guayama and Guamani along roads; near Mayaguez; near Quebradillas.-Florida Keys, Cuba, Jamaica, Haiti, St. Thomas, St. Croix, St. John (Eggers), St. Martin, St. Bartholomew (Stockholm Herbarium), 
Antigua, Guadeloupe, Martinique, St. Vincent, Bequia, Cannouan (Kew Bull. no. 81, p. 248), Union (do.), Barbados (Grisebach), Grenada, Trinidad (Grisebach), Margarita. Tropical and subtropical regions of both hemispheres. In the old World, however, it is a cultivated plant.

From the bark and leaves is made a medicament used in all wasting diseases; from the flowers and seeds another used for intermittent fever. The bast is employed in the manufacture of paper. Its whitish, close-grained wood is used for fuel and also makes good charcoal.

The plant is easily recognized on account of its peculiar habit. The primary petioles are very short, the pinnae extremely long and spine-pointed, the leaflets minute and sometimes almost abortive.

Local names, palo de rayo, flor de rayo. Jerusalem thorn (Cook and Collins).

\section{HAEMATOXYLUM L.}

\section{Haematoxylum L. Sp. Pl. 1: 384. 1753.}

Calyx with a short receptacle; segments 5 , subequal, deeply imbricate; petals 5 , oblong, spreading, nearly equal, imbricate in estivation; stamens 10 , free, nearly erect; filaments slightly pilose at the base; ovary subsessile, free, 2 or 3 ovulate; style filiform; stıgma small, terminal; legume lanceolate, compressed, membranous, adhering at the sutures, separating length wise in the middle of the valves into 2 boat-shaped false valves; seeds transverse, oblong, the chalaza ventral, albuminous.-Glabrous trees, the leaves paripinnate or bipinnate, the leaflets obovate, paucijugate; stipules sometimes spinous, sometimes small and caducous; flowers yellow, small, in lax axillary racemes; bracts small, caducous; bracteoles wanting.

\section{Haematoxylum campechianum L.}

(Urban, 277.)

Tree 5 meters high, the branches white-barked, often spiny; leaves paripinnate; leaflets 3 or 4-jugate, obovate, retuse, glabrous, 1.5 to $2.5 \mathrm{~cm}$. long; flowers yellow; calyx $4 \mathrm{~mm}$. long; petals oblong-obovate, $6 \mathrm{~mm}$. long.

Near Ponce, on the seashore; near Cabo Rojo, toward Puerta Real, on roadsides; near Mayaguez, on Mount Mesa; near Isabela, in forests near the seashore.-Bahama, Cuba, Jamaica, Cayman, Iaiti, St. Thomas, St. Croix, St. John, St. Bartholomew (Stockholm Herbarium), Antigua (Grisebach), Guadeloupe, Dominica, Martinique, St. Lucia (Grisebach), St. Vincent, Bequia, Mustique (Kew Bull. no. 81, p. 248), Grenada, Tobago, Trinidad. This tree is indigenous in Mexico and in Central America. It is widely diffused, however, either under cultivation or naturalized, in the West Indies, especially Jamaica, and in the northern part of South America, as well as in some parts of tropical Asia.

From the blood-red heartwood of the tree (which becomes black on exposure to the air) is made logwood (campeachy-wood), an exceedingly valuable dyestuff. The important crystalline principle of this wood, haematoxylin $\left(\mathrm{C}_{16} \mathrm{H}_{14} \mathrm{O}_{6}\right)$, is much use as a dyestuff to produce blue, violet, and black. The most valuable logwood comes from the west coast of Iucatan, the least valuable from the Antilles. The wood is of value in cabinet work, and the bark contains a gum from which one kind of India ink, also called chinese ink, is made. In the countries where the tree is indigenous the the bark, bast, and legumes are used by the people medicinally.

Local names, palo de campeche, campeche. 


\section{PUINCIANA L.}

Poinciana L. Sp. Pl. 1: 380. 1753.

Poincia Neck. Elem. 2: 449. 1790.

Delonix Raf. Sylva Tellur. 2: 92. 1836.

Calyx with a very short turbinate receptacle, sometimes with almost none; segments 5, nearly equal, valvate in estivation; petals 5 , round, imbricate, nearly equal, or the posterior one different from the others; stamens 10, free, deflexed; filaments slightly villous at the base, toward the top inflexed; ovary sessile, free, multiovulate; style filiform, stigma terminal, ciliolate, but slightly dilated; legume coriaceous, elongated, compressed, obliquely veined, 2-valved, with tissue between the seeds; seeds compressed, ellipsoidal or oblong, transversely disposed, albuminous.-Cnarmed trees; leaves bipinnate: leaflets small, numerous; stipules obscure; flowers handsome, orange or scarlet, corymbose at the ends of the branches; bracts small, caducous; bracteoles wanting.

\section{Poinciana regia Boj.; Hook. ${ }^{a}$}

(Urban, 278.)

Tree 15 to 20 meters high; leaves 20 to $40 \mathrm{~cm}$. long; pinnae 8 to 20 -jugate, multifoliolate; leaflets oblong, $7 \mathrm{~mm}$. long, $3 \mathrm{~mm}$. wide, blunt at each extremity, upon very short petioles; flowers scarlet; calyx $2.5 \mathrm{~cm}$. long; petals $5.5 \mathrm{~cm}$. long, the claw $2 \mathrm{~cm}$. long, the lamina orbicular, $3.5 \mathrm{~cm}$. in diameter; vexillum white with a pinkish tint; legume 12 to $37 \mathrm{~cm}$. long, 3 to $4.5 \mathrm{~cm}$. wide.

Cultivated and seemingly wild in Fajardo on the public squares; in Cabo Rojo, in the market place; near Mayaguez.-Bahama, Haiti, St. Thomas, St. Croix, Guadeloupe (Duss), Martinique, Margarita. Native of Madagascar, but cultivated on account of its beauty on the east and west coasts of Africa, in India, and in other parts of the Tropics.

This magnificent tree, with its bright scarlet flowers and fern-like leaves, is the handsomest of the Caesalpinioideae. Wood white, light, soft, and loose-grained; takes a fine polish.

Local names, flamboyán, flamboyán colorado.

\section{CAESALPINIA L.}

\section{Caesalpinia L. Sp. Pl. 1: 380. 1753.}

Calyx with short or very short receptacle; segments 5 , imbricate, the lowermost one concave or boat-shaped and usually larger than the others; petals 5, orbicular, sometimes oblong, spreading, strongly imbricate, subequal or the uppermost one smaller; stamens 10, free, deflexed; filaments usually villous or glandular at the base; ovary sessile, free, the ovules few; style terete, often filiform, sometimes clavate at the top; stigma terminal, truncate or concave; legume ovoid, oblong, lanceolate or falcate, compressed, sometimes with thickened sutures, coriaceous, flat or turgid, sometimes 2-valved, sometimes indehiscent or later slightly 2-valved, often pulpy between the seeds; seeds tranvserse, ovoid or globose, exalbuminous (or albuminous in $C$. pulcherrima).-Trees or often high-climbing shrubs, unarmed or with scattered prickles; leaves bipinnate; leaflets small and numerous or large and few, membranous or coriaceous; stipules various; flowers yellow or red, often handsome, in lax simple or panicled racemes, axillary or on the ends of the branches. Bracts wanting. 
The five Porto Rican species of this genus belong to four different sections. C. bonduc and C. crista are included in section 1, Guilandina. They are aculeate, scandent shrubs with membranous leaflets and echinate legumes.

C. sepiaria belongs to section 3, Sappania. It is a prickly climbing shrub with seeds that are as long as wide, and glabrous legumes.

C. pulcherrima, a shrub with beautiful fragrant flowers, is contained in section 4, Caesalpinaria. The long-exserted anthers and small membranous leaflets are also noticeable.

C. gillicsii, worthy of notice on account of its minute leaflets and lanceolate legumes, is included in section 6, Erythrostemon.

\section{KEY TO THE SPECIES.}

Flowers rather small with subsessile bracts, in spikes; petiole with prickles; legume with prickles.

With stipules; bracts of the pedicels horizontal, curved; seeds lead-colored.

1. C. crista.

Without stipules; bracts of the pedicels ereet; seeds yellow.

Flowers large, long-stipitate, without bracts, in showy racemes;

legume without prickles.

Petioles with prickles; leaves pilose.

2. C. bonduc.

Petioles without prickles; leaves glabrous.

Flowers showy, yellow; pedicels and petioles glandular; legume glandular.

Flowers showy, scarlet; pedicels and petioles glabrous; legume glabrous.

3. C. sepiaria.

4. C. gilliesii.

5. C. pulcherrima.

\section{Caesalpinia crista $\mathrm{L}$.}

(Urban, 278.)

Shrub, scandent, 4 meters high, aculeate; leaves bipinnate; leaflets 8 to 12 -jugate, ovate to ovate-oblong, 2 to $6 \mathrm{~cm}$. long, shortly and obtusely acuminate, membranous or subchartaceous; stipules conspicuous, cut into large segments; bracts beneath the buds horizontal or curved; flowers rusty yellow, calyx lobes $7 \mathrm{~mm}$. long; petals ovateoblong, $1 \mathrm{~cm}$. long; legume oblique, 5 to $7.5 \mathrm{~cm}$. long, $3.5 \mathrm{~cm}$. wide, turgid; seeds lead-colored.

In coast districts near Bayamon; near Humacao, in copses at Punta Candelero; near Patillas, around Guardaraya; near Guanica, in thickets at Salinas; near Mayaguez at Guanajibo.--Bermuda (Hemsley), Florida Keys, Bahama, Cuba, Jamaica, Haiti, St. Thomas, St. Croix, St. John, St. Martin (Stockholm Herbarium), St. Bartholomew, Guadeloupe, Dominica (Grisebach), Martinique, St. Vincent, Mustique (Kew Bull. no. 81, p. 248), Barhados, Grenada. Tropics of Asia, Africa, and America, Australia, and New Guinea.

Every part of the plant (root, leaves, seeds, bark) is valuable medicinally. There appears to be a difference of opinion regarding the properties of the roots, but all authors agree in extolling the virtues of the seed. For making bracelets, necklaces, and rosaries the seeds are much used, and in some countries the children use them for marbles.

Local names, mato de playa, mato azul. Cuba, guacalote prieto (Law, Morales), St. Thomas, gray nickars (Eggers); St. Croix, nickars (West); Guadeloupe, canrque grise, oeil de chat (Duchassaing, Duss); Martinique, yeux de chat (Duss, Hahn); Grenada, horse-eye, quashi (Broadway). 


\section{Caesalpinia bonduc (L.) Roxb.}

(Urban, 2is.)

Prickly trailing shrubs; leaves paripinnate; stipules none; primary and secondary petioles puberulous, bearing recurved prickles; leaflets 5 to 8 -jugate; ovate or elliptical, shortly acuminate, subcoriaceous, 4 to $8 \mathrm{~cm}$. long, 2.5 to $4.5 \mathrm{~cm}$. wide; flowers yellow; bracts beneath the buds erect; legume broadly ovate-oblong, convexcompressed, prickly; seeds yellow.

Near Isabela.-Florida Keys, Cuba, Jamaica, Cayman (Cockerell), Haiti (Plumier), Florida, Mexico, Java, Sumatra, Amboina, East Indies (Baker).

Local names, matos de playa. Cuba, guacalote amarillo (Sagra \& Sauv.); Jamaica, nicker tree (Sloane).

\section{Caesalpinia sepiaria Roxb.}

(Urban, 279.)

Shrub diffuse or trailing, 2 to 3 meters high, prickly, puberulous above; pinnae 6 to 10 - (rarely 4-) jugate; leaflets 8 to 12 -jugate, oblong, rounded, or subtruncate, 1 to $1.7 \mathrm{~cm}$. long, 5 to $6 \mathrm{~mm}$. wide, pale and puberulous or glabrescent beneath; stipules semisagittate, deciduous; petals $1.5 \mathrm{~cm}$. long, slightly exceeding the calyx; filaments shortly exserted, villous below; legume flat-compressed, at length tumid, 6 to $6.25 \mathrm{~cm}$. long, $1.5 \mathrm{~cm}$. wide.

Cultivated and seemingly spontaneous near Bayamon; near Pepino, along roadsides; around Enea; between San German and Lajas Arriba, along roadsides; near Maricao on declivities.-Cuba, Jamaica, Haiti, Guadeloupe, Dominica, Martinique, St. Vincent, Barbados, Grenada. Introduced from the East Indies, but naturalized in all of the Antilles.

Caesalpinia sepiaria is useful for making hedges.

Local name, zarza; Guadeloupe and Martinique, croc à chien, arrête-boufs, fernambouc, gendarme, arrête-nègre.

\section{Caesalpinia gilliesii Wall.}

(Urban, 279.)

Tree, 1 to 4 meters high, unarmed; branches at first glandular; leaves imparipinnate; pinnae 10 to 20 -jugate; leaflets 8 to 15 -jugate, petioles glandular, subsessile, oblong, obtuse, 4 to $8 \mathrm{~mm}$. long, 2 to $3 \mathrm{~mm}$. wide, membranous; racemes 15 to $30 \mathrm{~cm}$. long, simple; pedicels 2 to $3 \mathrm{~cm}$. long, glandular-viscous; calyx lobes oblong, 2 to 2.5 $\mathrm{cm}$. long; petals broadly obovate, 2.75 to $3.5 \mathrm{~cm}$. long, yellow; legume oblique, slightly falcate, compressed, glandular, $7.5 \mathrm{~cm}$. long; seeds ovate.

Cultivated near Guanica. Native country, Argentina.

Local name, espiga de amor.

\section{Caesalpinia pulcherrima (L.) Sw.}

$$
\text { (Urban, 279.) }
$$

Tree, small, glabrous, 3 to 5 meters high; branches unarmed, often with a glaucous bloom; leaves bipinnate, 12 to $24 \mathrm{~cm}$. long; pinnae 4 to 9-jugate; leaflets 5 to 12 -jugate, obovate or oblanceolate-oblong, 1.5 to $2 \mathrm{~cm}$. long, 8 to $9 \mathrm{~mm}$. wide; racemes terminal and from upper axils, bearing many showy, variegated, yellow and carmine, or rarely pale yellow, flowers on long pedicels ( 5 to $7.5 \mathrm{~cm}$.); calyx lobes glabrous, about $9 \mathrm{~mm}$. long; petals usually 1 to $2.5 \mathrm{~cm}$. long; legume coriaceous, flat, 5 to $9 \mathrm{~cm}$. long, $1.5 \mathrm{~cm}$. broad above, glabrous; seeds obovate-quadrate, compressed. 
Cultivated and seemingly spontaneous near Bayamon; near Yabucoa; near Utuado, at Salto Arriba; near Mayaguez.-Florida Keys, Bahama (Dolley), Cuba, Jamaica, Cayman (Hitchcock), Haiti, St. Thomas, St. Croix, St. Martin (Stockholm Herbarium), St. Bartholomew (do.), St. Kitts, Antigua (Grisebach), Guadeloupe, Martinique, St. Vincent, Barbados (Sloane), Grenada, Tobago, Trinidad (Grisebach). The plant is also found in America, Asia, and Africa. Native country unknown.

This elegant bush remains in flower all the year. In one variety the flowers are red, in another yellow. The leaves, flowers, and seeds are largely used in native medicine.

Local name, clavellina. Cuba, cuacamaya (Sagra); Jamaica, flower fence of Barbados or wild senna or Spanish carnation (Sloane), Barbados pride (P. Brown, Macfadyen); France, poinciade or fleurs de paradis (Jacquin); Haiti, poincellade (Jäger, Buch); Danish Islands, dudeld $\iota$ (Eggers); Guadeloupe, baraguette (Duchassaing, Duss); Martinique, arrête-boufs (Duss); Barbados, flower fence or Spanish carnation (Hughes); Tobago, dudeldu (Eggers).

\section{MYROSPERMUM Jacq.}

Myrospermum JACQ. Enum. Pl, Carib. 4. 1760.

Calusia Bert.; DC. Prod. 2: 94. 1825, as section.

Calyx inflexed-turbinate, with very short, wide, membranous teeth; standard obovate, the 4 inferior petals free, almost alike, curved, lanceolate, acute; stamens free, persistent, with long filaments and small anthers; ovary stipitate, 2 to manyseeded; style subulate, almost straight, with a small terminal stigma; pod stipitate, compressed, indehiscent, with one seed at the apex, narrowed to the base, 2-winged, the wing of the upper suture broader than that of the lower; seeds oblong.-Tree with imparipinnate leaves; leaflets with pellucid lines and dots; flowers rather large, in terminal racemes.

\section{Myrospermum frutescens Jacq.}

(Urban, 279.)

A small tree, 3 to 5 meters high or a large one 20 meters high; leaflets 5 to 7 -jugate, 2 to $2.5 \mathrm{~cm}$. long, membranaceous, oblong or oval, roundish, retuse or blunt at the apex, glabrous, striate with pellucid lines; flowers white, the standard striped in the middle with green; legume 5 to $7.5 \mathrm{~cm}$. long (including the wing), as broad as the wing, which tapers at the base into a short stalk.

Cultivated and seemingly wild near Coamo; near Peñuelas, near Utuado, in a thicket of Coffea arabica at San Andres; near Mayaguez.-St. Croix (Eggers). Native countrr Trinidad, Central America, Colombia, Venezuela.

Local names, cereipo, sereipo.

26. ORMOSIA Jacks.

Ormosia JAcks. Trans. Linn. Soc. 10: 360. pls. 25, 27. 1811.

Macrotropis DC. Prod. 2: 98.1825.

Calyx campanulate with the 2 upper teeth subconnate and usually longer and wider, often incurved; petals unguiculate; standard suborbicular or cordate; wings oblique. obovate-oblong; keel with the petals free; stamens free, unequal, all or all but one or two perfect; anthers versatile; ovary subsessile, biovulate or multiovulate; style filiform, involute at the apex; stigma introrse, lateral; pod oblong or more rarely linear, usually short, compressed, coriaceous, fleshy or woody, 2-valved, continuous or septate between the seeds; seeds obovate or oblong, rather thick, shiny, scarlet or spotted with black.-Trees with imparipinnate or abruptly pinnate leaves; leaflets coriaceous; flowers white, lilac, or blackish purple in terminal, more rarely axillary, panicles, sometimes in racemes. 


\section{Ormosia krugii Urb.}

(Urban, 280.)

Tree 10 to 25 meters high; leaves 7 to 9 -foliolate; petioles $20 \mathrm{~cm}$. long; leaflets 7 to $15 \mathrm{~mm}$. long, petiolulate, oval or oval-elliptical, obovate or ovate, rounded or truncate at the top, rounded or subtruncate at the base, 7 to $25 \mathrm{~cm}$. long, 3.5 to $14 \mathrm{~cm}$. wide, coriaceous, upper surface glabrous, lower surface with minute adpressed hairs; inflorescence sometimes $35 \mathrm{~cm}$. long, axillary or terminal, paniculate or subcorymbose; calyx $10 \mathrm{~mm}$. long, pilose; petals dark violet; standard suborbicular, $12 \mathrm{~mm}$. wide, spotted with white or pale yellow; wings oblique, obovate-cuneate; keel petals free, oblique, oblong, 13 to $14 \mathrm{~mm}$. long; ovary 4 to 6 -ovulate; pod $10 \mathrm{~cm}$. long, $2 \mathrm{~cm}$. wide, constricted between the seeds; seeds suborbicular or obovate-orbicular, 10 to $12 \mathrm{~mm}$. long, 6 to $9 \mathrm{~mm}$. thick, carmine-red or spotted with black.

In the primeval woods near Bayamon; near Juncos, on Mount Guvuy; Sierra de las Piedras, on Mount Frances; near Yabucoa, on Mount Piedra Azul at Jácana and on Mount Cerro Gordo; near Adjuntas, on Mount Andubo and Mount Cedro; near Utuado, at Roncador; in Sierra de Lares at Guajataca.-Dominica at Castle Bruce.

Local names, matos or palo de matos, peronia.

\section{SOPHORA L.}

\section{Sophora L. Sp. PI. 1: 373. 1753.}

Calyx teeth short; standard obovate or orbicular, erect or spreading; wings oblong, oblique; keel oblong, nearly straight, its petals usually imbricate or coherent along the back; stamens perigynous or nearly hypogynous, free or rarely slightly connate at the base; anthers versatile; ovary short-stalked, multiovulate; style incurved; stigma minute, terminal; pod moniliform, terete or slightly compressed, coriaceous and indehiscent in our species; cotyledons thick, the radicle sometimes straight and short, sometimes longer and inflexed.-Trees or shrubs with imparipinnate leaves; leaflets sometimes small and numerous, sometimes few and large, often with stipels: flowers white, rarely a bluish-violet, in simple terminal racemes, these sometimes aggregated in panicles.

\section{Sophora tomentosa L.}

(Urban, 280.)

A robust, erect shrub, 2 to 3 meters high, the branches densely argenteous; petiole $2.5 \mathrm{~cm}$. long; rachis 5 to $10 \mathrm{~cm}$. long; leaflets 15 to 19 , nearly sessile, oblong, 4 to $5 \mathrm{~cm}$. long, slightly mucronate, the base slightly rounded, subcoriaceous, both sides densely and permanently coated with adpressed gray-silvery tomentum; flowers in lax 12 to 30 -flowered axillary and terminal racemes; pedicels 0.6 to $1.2 \mathrm{~cm}$. long, argenteous, with a lanceolate or linear bract at the base; calyx campanulate, 6 to $8 \mathrm{~mm}$. deep, subtruncate, argenteous; corolla, bright yellow, $1.8 \mathrm{~cm}$. deep; pod 12.5 to $15 \mathrm{~cm}$. long, with 5 to 8 coriaceous segments 6 to $8 \mathrm{~mm}$. thick, connected by narrow necks.

Near Guanica, at Salinas; near Mayaguez in coast districts toward Guanajibo.Bermuda (Hemsley), South Florida (Chapman), Bahama (Hitchcock), Cuba, Jamaica, Haiti, St. Thomas, St. Croix (Eggers), Antigua (Grisebach), Guadeloupe (do.), Marie Galante, Martinique, St. Lucia, St. Vincent, Union (Kew Bull. no. 81, p. 248). A cosmopolitan of the Tropics, often found on the seashore. 


\section{CROTALARIA L.}

Crotalaria L. Sp. Pl. 2: 714. 1753.

Clavulium Desv. Ann. Sc. Nat. 9: 407. 1826.

Maria-Antonia PARL. Mar. Ant. Nov. Gen. 3. 1844.

Calyx laciniae free or more rarely the two upper ones and the three lower ones more or less united; standard orbicular, more rarely ovate, usually callous above the short claw; wings oblong or obovate, shorter than the standard; keel incurved or angled, terminating inwards in a straight or incurved beak, rarely almost obtuse and not beaked; stamens all united in a sheath open along the upper side; anthers alternately long and erect and short and versatile; ovary sessile or distinctly stalked, with 2 or more ovules; style much incurved or suddenly bent inward, with a longitudinal line of hairs above the middle on the inner side; stigma terminal; pod round or oblong, turgid or inflated, 2-valved, continuous within; seeds with a filiform funiculus.Herbs, shrubs, or undershrubs; leaves alternate, simple or digitately compound with usually 3 , rarely 1 or 5 or 7 leaflets; stipules free from the petiole, occasionally decurrent along the stem, sometimes large and foliaceous, sometimes small, rarely wanting; flowers yellow, more rarely blue or purple, in simple racemes terminal, becoming sometimes leaf-opposed, more rarely solitary; bracteoles small, on the peduncle or adnate to the caly $\mathrm{x}$ tube, rarely wanting.

KEY TO THE SPEC1ES.

Leaves simple (Section Simplicifoliae Benth.).

Stipules foliaceous, broadly decurrent, with a semilunar, incurved top; leaves oval or oblong, sessile or subsessile; peduncle lateral, elongated, few-flowered; calyx 5-parted, usually as long as the corolla.

Peduncles reaching $10 \mathrm{~cm}$; ; flowers many; leaves reaching 7 cm.; pods stipitate.

1. C.stipularia.

Peduncles short, about 3 -flowered; leaves $5 \mathrm{~cm}$. long; pod subsessile.

Stipules wanting; leaves cuneate-oblong, shortly petioled, retuse or very obtuse or faintly mucronate at the top; flowers in lax terminal, elongated, many-flowered racemes; calyx bilabiate, exceeded by the corolla.

2. C. sagittalis.

3. C. retusa.

Leaves digitately trifoliolate (Section Trifoliolatae Baker).

Racemes both lateral and terminal, laxly 6 to 12 -flowered, 5 to 10 $\mathrm{cm}$. long, on peduncles 2.5 to $10 \mathrm{~cm}$. long; corolla bright yellow; leaflets obovate or orbicular, 2.5 to $4 \mathrm{~cm}$. long, the common petiole 4.5 to $5.5 \mathrm{~cm}$. long; pod oblong, broad, turgid, clothed with fine spreading hairs like those of stem.

4. C. incana.

Flowers 1 to 4 together in the axils of many of the leaves, if more than one racemose or umbellate; corolla yellow, faintly veined; leaflets elliptical-lanceolate, 1 to $2 \mathrm{~cm}$. long, 7 to $9 \mathrm{~mm}$. wide, common petiole 2 to $3.5 \mathrm{~cm}$. long; peduncles short, $5 \mathrm{~mm}$. long; pod glabrescent.

\section{Crotalaria stipularia Desv.}

5. C. lotifolia.

( Trban, 280.)

Annual, erect, 0.33 meter high or higher; leaflets oval or oblong, 2.5 to $7 \mathrm{~cm}$. long, 1 to $2.25 \mathrm{~cm}$. wide, sessile, subhirsute-pubescent on both sides; peduncle $5 \mathrm{~cm}$. long; flowers yellow, small; calyx 5-parted, usually as long as the corolla, fulvopilose; 
segments lanceolate; corolla about $1 \mathrm{~cm}$. long; legume 2.5 to $3.5 \mathrm{~cm}$. long, $8 \mathrm{~mm}$. wide, glabrous.

Near Bayamon along roads; near Coamo; near Mayaguez, on hills at Boquillas and in coast districts at Algarrobo.-Cuba, Haiti, St. Kitts, Guadeloupe, Dominica, Martinique, St. Vincent, Trinidad (Grisebach), Mexico. Frequent in the warmer regions of South America.

Local name, cascabelillo.

\section{Crotalaria sagittalis L.}

(Trban, 280.)

Annual, hairy; stem 10 to 20 (sometimes 30 ) $\mathrm{cm}$. high, erect, branching: leaves simple, oval or oblong-lanceolate, 2.5 to $5 \mathrm{~cm}$. long, pubescent with long, soft hairs, scarcely petioled; stipules occasionally wholly wanting, usually present, united and decurrent on the stem, obversely sagittate, nearly all, but especially those of the upper leaves, large, the free portion triangular-lanceolate; peduncles rather short, about 3-flowered, opposite the leaves; corolla rather shorter than the calyx; legume scarcely stipitate, coriaceous, several-seeded; seeds small, shining, black when ripe, rattling in the inflated legume.

Near Bayamon, in fields on the coast at Catano; near Yauco on Mount Duey.Jamaica, Haiti, North America, Mexico, and as far as Peru.

\section{Crotalaria retusa $\mathrm{L}$.}

$$
\text { (Urban, 281.) }
$$

Annual, erect, 1 meter high; leaflets 5.5 to $7.5 \mathrm{~cm}$. long, 2 to $3 \mathrm{~cm}$. wide, very shortpetioled, glabrous above, sericeo-canescent beneath; raceme 15 to $30 \mathrm{~cm}$. long; flowers yellow, the standard variegated; calyx bilabiate, exceeded by the corolla; corolla 1.5 to $2.25 \mathrm{~cm}$. long; legume $3 \mathrm{~cm}$. long, $1.25 \mathrm{~cm}$. wide, glabrous.

Near Bayamon along roads; near Cataño; near Cabeza de San Juan; near Maunabo, at Punta de la Tuna; near Patillas, in coast districts at Guardaraya; near Cabo Rojo in pastures; near Mayaguez, on Mount Mesa.-Bahama, Cuba, Jamaica, Haiti, St. Thomas, St. Croix, St. John (Eggers), St. Martin (Stockholm Herbarium), St. Bartholomew (do.), St. Kitts, Guadeloupe, Dominica, Martinique, St. Vincent, Mustique, Bequia (Kew Bull. no. 81, p. 244), Union (do.), Barbados, Grenada, Tobago, Trinidad. Found in the warm regions of the globe; frequent in East India and in the Antilles.

The leaves and roots of Crotalaria retusa are used in popularmedicine, and in Farther India it is sometimes cultivated for its fiber.

Local names, matraca, sonajuelas; according to Stahl (cited by Cook and Collins, p. 129), cacsabelillo grande.

\section{Crotalaria incana L.}

(Urban, 281.)

Annual or biennial, herbaceous, 0.66 to 1.33 meters high; branches clothed with fine spreading brown silky hairs; leaflets obovate or orbicular, 2.5 to $4 \mathrm{~cm}$. long, 2 to $2.5 \mathrm{~cm}$. wide, glabrescent above, slightly silky beneath; petioles 4.5 to $5.5 \mathrm{~cm}$. long; flowers greenish yellow; calyx deeply 5-lobed, segments lanceolate, exceeded by the corolla; corolla 1 to $1.25 \mathrm{~cm}$. long; legume pendulous, 2.5 to $3.5 \mathrm{~cm}$. long, about $1 \mathrm{~cm}$. wide.

Near Bayamon along roads; near Cabeza de San Juan on declivities; near Fajardo on the river bank; near Juncos along roads; near Guayama; near Cayey along roads; near Coamo on roads; near Adjuntas at Coral Viejo, near Guanica in thickets at the lagoon; near Cabo Rojo, in pastures at Miradero; near Mayaguez at the fortress and on the declivities of Mount Mesa; between Mayaguez and Anasco along roads; near Rincon in thickets on the seashore.-South Florida (Chapman), Cuba, Jamaica, Cayman 
(Hitcheock), Haiti, St. Thomas, St. Croix, St. Martin (Stockholm Herbarium), St. Bartholomew (Euphrasén), Antigua (Grisebach), Guadeloupe, Dominica (Grisebach), Martinique, St. Vincent, Bequia, Mustique (Kew Bull. no. 81, p. 244), Barbados, Grenada, Tobago, Trinidad, Margarita. Cosmopolitan in the warm regions of the world, but perhaps an introduction in the old World.

Local name, cascabelillo vacío.

\section{Crotalaria lotifolia L.}

\section{(Urban, 281.)}

Shrubby, diffuse, 0.5 to 2 meters high; leaves 5 to $7 \mathrm{~cm}$. long, sericeous on both sides; peduncle $5 \mathrm{~mm}$. long; flowers pale yellow; vexillum with red curving lines on the inner side at the base; calyx deeply 5-parted, shortly exceeded by the corolla, lobes lanceolate; corolla about $1.25 \mathrm{~cm}$. long; legume spathulate-oblong, puberulous, $2 \mathrm{~cm}$. long, $6 \mathrm{~mm}$. wide.

Near Fajardo in shady places; near Coamo, in the woods of Mount Ildefonso and in thickets on the Juey River toward Salinas; near Guanica, in shady meadows at Montalba and in thickets on the seashore; near Salinas de Cabo Rojo at Punta de Aguila.Cuba, Jamaica, Haiti, St. Thomas, St. Croix (Eggers), St. John; the varieties grandifolia and grandiflora in Martinique, Barbados, and tropical west Africa. A wellknown very distinct West Indian species.

Local name, cascabelillo axilar (Cook and Collins).

\section{INDIGOFERA L.}

\section{Indigofera L. Sp. Pl. 2: 751. 1753.}

Acanthonotus Benth. in Hook. Niger Fl. 293. 1849.

Sphaeridiophorum Desv. Journ. Bot. 3: 125. pl. 6. 1814.

Brissonia Desv. Ann. Sc. Nat. 9: 411. 1826.

Calyx small, oblique, campanulate or tubular, teeth equal or the lowest longest; standard obovate, oblong, or suborbicular, sessile or shortly unguiculate; wings more or less oblong, adhering a little to the keel; keel straight or slightly curved, obtuse, or acuminate, gibbous or spurred on both sides; upper stamen free from the base, the others connate; anthers uniform with glandular, apiculate or penicillate-pilose connective; ovary sessile or nearly so, with several or rarely 1 or 2 ovules; style incurved, short, filiform, usually somewhat curved; stigma terminal, capitate or penicillatepilose; pods oblong, linear or rarely globular, terete or rarely flattened, straight or incurved, 2-valved, divided transversely between the seeds by cellular tissue; seeds globular, or truncate at each end, or flattened.-Herbs, undershrubs, or shrubs with adpressed silky lairs fixed by the middle, and sometimes mixed with loose hairs or tommentum; leaves unequally pinnate, more rarely digitate, 3 -foliolate or reduced to 1 leaflet, sometimes simple; leaflets entire; stipules usually small, setaceous, somewhat adnate to the petiole; flowers usually rose-red or purplish red, axillary, rarely sessile, in racemes or spikes, these sometimes united into panicles.

KEY TO THE SPECIES.

Pod reflexed, sickle-shaped, 6 to 8 -seeded.

Pod straight, shorter than in I. suffruticosa, 3 or 4-seeded.

1. I. suffruticosa.

2. I. guatimalensis.

\section{Indigofera suffruticosa Mill.}

(Urban, 282.)

A copiously branched shrub 1 to 1.5 meters high; branches straight, woody, deeply sulcate, thinly silvery; stipules small, setaceous; petiole under $2.5 \mathrm{~cm}$. long, firm, erecto-patent; leaves 5 to $10 \mathrm{~cm}$. long, leaflets 6 to 8 -jugate, oblong or obovate, 2 to 2.5 
cm. long by about half as broad, the lateral ones opposite, short-stalked, both sides subglaucous and thinly silvery, the upper nearly or quite glabrous when mature, turning blackish when dried; racemes moderately dense, 2.5 to $5 \mathrm{~cm}$. long when in flower, nearly sessile; pedicel equaling the obliquely campanulate, thinly silvery calyx, which is not more than $1 \mathrm{~mm}$. deep, the lower teeth lanceolate, reaching half way down, the upper shorter; corolla fugacious, yellow, 3 to $4.5 \mathrm{~mm}$. long.- Pod reflexed, sickleshaped, 1 to $2 \mathrm{~cm}$. long, $3 \mathrm{~mm}$. thick, subtetragonous with thickened sutures, glabrous when mature, 6 to 8 seeded.

Near Bayamon in cultivated localities; Sierra de Naguabo, near Rio Blanco; near Yabucoa in the coast districts; near Patillas on the sea at Guardaraya; near Coamo, in meadows between Serillos and Salinas; near Adjuntas on declivities at Saltillo; near Guayanilla on calcareous mountains near Peñon; near Guanica, in fields at Punta de los Pescadores and in coast districts near La Ballena; near Cabo Rojo in pastures; near Mayảguez and Añasco.-Bahama, Cuba, Jamaica, Cayman (Hitcheock), Haiti, St. Thomas, St. Croix, St. John, St. Bartholomew (Stockholm Herbarium), Guadeloupe, Martinique, St. Vincent, Mustique, Bequia (Kew Bull. no. 81, p. 245), Barbados, Grenada, Tobago, Trinidad (Grisebach), Margarita. It is said to be a native of tropical America.

Indigofera suffruticosa is much cultivated in the tropics and subtropics and from it is prepared the well-known coloring matter, indigo. It is obtained in the following manner. The plants are mowed just before the flowering time and soaked in water until the liquid becomes a deep yellowish-green color. The fluid is then drained into large vessels or into a cistern, where it is brought, as much as possible, in contact with the air, by means of wheels and shovels, in order that it may take up oxygen. The indigo substance becomes blue and insoluble in water, and sinks to the bottom in the form of a blue powder. This is strained out by woolen cloths and dried. Indigo finds extensive use as a dyestuff, coloring cotton, wool, and silk dark blue. Mixed with oil, it forms a paint of great body, but one that is easily decomposed by pure air.

Local name, añil, indigo.

\section{Indigofera guatimalensis Moç. \& Sessé.}

(Urban, 282.)

Shrub, 1.5 meters high; branches woody, deeply sulcate, thinly silvery; stipules small, setaceous; petiole about $1 \mathrm{~cm}$. long, firm erecto-patent; leaves 4.5 to $6 \mathrm{~cm}$. long; leaflets 4 to 6 pairs, oblong or obovate, 1 to $2 \mathrm{~cm}$. long, $5 \mathrm{~mm}$. broad, the lateral ones opposite, short-stalked, the upper one with a petiolule $5 \mathrm{~mm}$. long, all clothed on both sides with rather long gray hairs; racemes 1 to $1.5 \mathrm{~cm}$. long, nearly sessile; pedicel about $1 \mathrm{~mm}$. long; calyx pilose, $1 \mathrm{~mm}$. deep; corolla $3 \mathrm{~mm}$. long; pod erect, straight, subtetragonous, pilose, $1 \mathrm{~cm}$. long, $2 \mathrm{~mm}$. wide, with thickened sutures, 3 or 4 -seeded.

Near Cabo Rojo in pastures; near Mayaguez, on hills toward Boquillas; near Rincon on declivities at Calvache.-Cuba (cultivated, Prain and Baker), St. Thomas, Martinique (introduced), Guatemala (Prain and Baker), Venezuela, Ecuador (Prain and Baker), Peru.

This plant differs from $I$. suffruticosa in having thick pods which are smaller and fewer-seeded.

\section{DALEA L.}

Dalea Juss. Gen. 355. 1789, not P. Br. 1756.

Parosela CAv. Dese. 185. 1802.

Calyx 5-cleft or 5-toothed, often glandular; the segments subequal; petals unguiculate, the claws of the wings and keel united with the stamen-tube to the middle, deciduous by an articulation; standard free, inserted at the bottom of the calyx, the $\operatorname{limb}$, cordate; stamens 10 (rarely 9 ) monadelphous, the tube cleft; ovary sessile or-shortly 
stipitate with 2 , rarely 3 to 6 seeds; legume membranous, inclosed in the calyx, indehiscent, usually with only 1 seed.-Herbaceous or somewhat shrubby plants, dotted with glands; leaves unequally pinnate (rarely trifoliolate); leaflets small, usually numerous, rarely 3 , very rarely only 1 , entire; stipules minute, setaceous; flowers white, blue, purple, rarely yellow; spikes pedunculate, terminal or opposite the leaves, dense, often capitate, rarely loosely-flowered.

\section{Dalea domingensis DC.}

(Urban, 283.)

Herbaceous or somewhat shrubby, 0.5 to 2 meters high; stem branched above, leaves 4 to $5 \mathrm{~cm}$. long; leaflets 3 to 5 pairs, oblong or obovate-oblong, 10 to $13 \mathrm{~mm}$. long, 5 to $6 \mathrm{~mm}$. wide, entire, emarginate, the base cuneate, gray-silky on both sides, with pellucid glandular dots; petiolule about $1 \mathrm{~mm}$. long; spikes terminal or opposite the leaves, about $2 \mathrm{~cm}$. long; calyx with long, beautifully plumose setaceous teeth, glandular; corolla $11 \mathrm{~mm}$. long; flowers purple, rose-colored and white in the same spike; standard small, cordate, with several small glands near the middle; pod membranaceous.

Between Coamo and Salinas, in meadows; near Yauco, in meadows by the river near the town; near Guanica, in thickets on the seashore near Cano Gordo.-Cuba, Haiti, St. John. From Texas and New Mexico to Venezuela and Colombia.

\section{TEPHROSIA Pers.}

Cracca L. Sp. Pl. 2: 752.1753.

Tephrosia PErs. Syn. 2: 328. 1807.

Calyx-teeth or lobes subequal, or the lower larger than the rest, the 2 upper ones more united; petals unguiculate; standard suborbicular, often tomentose or sericeous on the outside; wings obliquely obovate or oblong, adhering a little to the keel; keel incurved, obtuse or subacute; upper stamen free to the base or middle; anthers uniform; ovary sessile, with many or rarely 1 or 2 ovules; style incurved or inflexed, more or less flattened with a terminal stigma, often slightly penicillate; pod linear, or rarely ovate, flattened, 2-valved, continuous or slightly septate within; seeds often with a small strophiole.-Herbs, undershrubs, more rarely shrubs: leaves imparipinnate; leaflets numerous, rarely only 1 to 3 , the veins in most species numerous, parallel and oblique to the midrib; stipules setaceous or wider and then striate; flowers red, purple, or white, in pairs or clusters, in terminal, leaf-opposed, or rarely axillary racemes, the lower clusters occasionally or sometimes all in the axils of the leaves.

$$
\text { KEY TO THE SPECIES. }
$$

Perennial with a thick rhizome; stipules subulate or lanceolate;

leaves 5 to 7 -jugate; leaflets obtuse, with a mucro; flowers 1 to 1.5 cm. long, pale purple.

Stipules setaceous: leaves 2 or 3 -jugate; leaflets obtuse, emarginate;

flowers $7 \mathrm{~mm}$. long, blood-red.

1. T. cinerca.

2. T. catisartica.

1. Tephrosia cinerea (L.) Pers, $\alpha$

('rrban, 283.)

Perennial with a thick rhizome, 33 to $45 \mathrm{~cm}$. high; leaves 5 to 7 -jugate; leaflets cuneate-oblong or linear, obtuse, mucronate, 2 to $2.5 \mathrm{~cm}$. long. \& to $9 \mathrm{~mm}$. wide: stipules lanceolate or subulate; raceme 7.5 to $15 \mathrm{~cm}$. long; flowers pale purple or rose-colored. 10 to $15 \mathrm{~cm}$. long; calyx $5 \mathrm{~mm}$. deep; standard $11 \mathrm{~mm}$. long; pod 3.5 to $4.5 \mathrm{~cm}$. long. 4 $\mathrm{mm}$. wide, 5 to 9 -seeded. 
Near Bayamon, in coast districts at Cataño; near Cabeza de San Juan, in coast districts; near Patillas, in thickets on the seashore at Guardaraya; near Coamo, around Los Baños along roads, in the valley of El Tendal River in roeky ground, on El Fuerte River, and near the Salinas Lagoons; near Peñuelas; near Yauco; near Guanica, in coast districts between Barina and La Boca and at Salinas; near Salinas de Cabo Rojo at Los Morillos; near Mayaguez, in coast districts at Algarrobo; near Rincon at Cabo San Francisco.-Bahama, Cuba, Jamaica, Cayman (Millspaugh), Haiti, St. Thomas, St. ('roix, St. John (Eggers), St. Martin (Stockholm Herbarium), St. Bartholomew (do.), St. Kitts (Grisebach), Antigua (do.), Guadeloupe, Désirade (Grisebach), Marie Galante (Duss), Dominica (Grisebach), St. Vincent, Tobago, Margarita, Curaçao. Tropical continental America.

On account of the strong resemblance of the Tephrosia species, it is often difficult to distinguish them. T. cinerea differs from T. purpurea in having calyx teeth that are almost twice as long as the tube. The racemes are also shorter in T. cinerea.

In tropical America the young branches and leaves of this plant are crushed and mixed with quicklime, and the mixture used for narcotizing fish.

Local name, añll cenızo.

\section{Tephrosia cathartica (Sessé \& Moẹ.) Urb.๕}

(Urban, 283.)

The stem woody, branches firm, angular, thinly gray-silky; stipules setaceous, minute, $2 \mathrm{~mm}$. long; leaves 5 to $7 \mathrm{~cm}$. long, imparipinnate, 2 to 3 -jugate; leaflets oblong or obovate-oblong, 1.4 to $3.5 \mathrm{~cm}$. long, 6 to $12 \mathrm{~mm}$. wide, gray-silky on both sides, entire, blunt, emarginate, papyraceous; petiolule of lateral leaflets $1 \mathrm{~mm}$. long, that of terminal one $6 \mathrm{~mm}$.; racemes both terminal and leaf-opposed, lax, 5 to $15 \mathrm{~cm}$. long; flowers solitary or in pairs, bracts minute; pedicel about $2 \mathrm{~mm}$. long; calyx 4 $\mathrm{mm}$. long, pilose outside, the lanceolate, acuminate teeth exceeding the tube; flowers blood-red, $7 \mathrm{~mm}$. long; pod linear, downy, $3.5 \mathrm{~cm}$. long, $5 \mathrm{~mm}$. wide, stipitate, $5 \mathrm{or}$ 6 -seeded.

Near Mayaguez, in coast districts at Algarrobo; near Rincon at Cabo San Francisco; near Vega Baja, in sandy soil.-Bahama, Cayman, Haiti, St. Kitts, Trinidad, Ruatán Island (Bay of Honduras), Cartagena.

Poiret says that Cytısus sessiliflorus Poir. has been collected in Porto Rico, but the original specimen was probably collected by Ledru or Riedlé in Trinidad, not in Porto Rico.

\section{BARBIERIA DC.}

Barbuerza DC. Prod. 2: 239. 1825.

Barbiera SPRENG. Gen. 2: 587. 1831.

Calyx long-tubuliform, with acute subequal segments; petals with long claws; standard oblong, narrowed below into a claw; wings oblong, adhering to the keel; petals of the keel longer than the wings, obtuse; upper stamen free, the others connate; anthers uniform; ovary sessile, multiovulate; style long, slender, bearded on the inner side; pod linear, straight, compressed, 2-valved, indented between the seeds on the outside, septate; seed transverse, oblong.-Shrubs; leaves imparipinnate; leaflets entire, numerous; stipels long, subulate; stipules acuminate-subulate; flowers 2 or 3 together, in terminal or axillary racemes, rather large, red; bracts and bracteoles lanceolate-subulate.

a Cook and Collins, p. 128, as Cracca leptostachys.

25734-roL 10 , PT $4-07-4$ 
1. Barbieria pinnata (Pers.) Baill.$^{a}$

(Urban, 284.)

Herb or undershrub, 0.5 to 4 meters high; leaflets 15 to 21 , oblong or ovate-oblong, stipellate, 2 to $4 \mathrm{~cm}$. long, 1 to $1.25 \mathrm{~cm}$. wide, mucronate, membranous, with scattered hairs above, appressed-sericeous below; racemes 8 to $10 \mathrm{~cm}$. long; flowers vermilion; calyx tube $19 \mathrm{~mm}$. long, calyx teeth $10 \mathrm{~mm}$. long, colored; corolla 5 to $6 \mathrm{~cm}$. long; standard twice as long as the calyx; pod 5 to $6.5 \mathrm{~cm}$. long, $6 \mathrm{~mm}$. broad, pilose; seeds black.

Near Bayamon, in shady places; near Utuado, on slopes at Pellejas; near Maricao, on slopes; near Lares, on shady slopes at Palma Llanos; near Mayaguez, on Mount Mesa and at Mayaguez-Arriba; near Aguada, in the forests at Piedra Blanca.-Cuba, Haiti, tropical South America.

Noticeable are the long calyx and showy red flowers of this species. It has also long, pinnate leaves, with many leaflets, which are pubescent on the lower surface.

Local name, enredadera.

33. GLIRICIDIA H. B. K.

Gliricidia H. B. K. Nov. Gen. \& Sp. 6: 392, 393. 1823.

Calyx teeth broad, short, the two upper ones subconnate; standard large, reflexed, sometimes with a pair of inflexed auricles at the base; wings arcuate-oblong, transversely plicate, free; keel obtuse, inflexed; upper stamen free, the rest connate, forming a sheath; anthers uniform; ovary stipitate, multiovulate; style awl-shaped, inflexed, glabrous, or beneath the stigma somewhat hairy; stigma small, terminal; pod stalked, broadly linear, unwinged, 2-valved, not septate within, the valves coriaceous.-Trees or shrubs; leaves imparipinnate; leaflets entire, not stipellate; stipules small; flowers rose-colored, in axillary racemes, or in fascicles on the old wood; bracts and bracteoles small or wanting.

\section{Gliricidia sepium (Jacq.) Steud.}

(Urban, 284.)

Tree 8 meters high or higher; leaflets 9 to 17 , ovate-oblong or ovate-lanceolate, broadly acuminate, obtuse at the apex, 3.5 to $6.5 \mathrm{~cm}$. long, 1.5 to $2 \mathrm{~cm}$. wide, subcoriaceous, subglabrous; flowers in many-flowered racemes, rose-colored; calyx with 5 very small teeth, glabrous or slightly pilose outside, 4 to $5 \mathrm{~mm}$. deep; standard 20 to $25 \mathrm{~mm}$. long, rose-colored, yellow above the base, keel inflexed; ovary glabrous; pod 10 to $20 \mathrm{~cm}$. long, 1.1 to $2 \mathrm{~cm}$. broad, subligneous.

Near Añasco. Not indigenous in Porto Rico, but introduced from Cuba (Gundlach); Jamaica (Hansen); Haiti (Picarda); Domingo (Millspaugh).-Mexico, Nicaragua, Guatemala, Yucatan, Panama.

In the specimens from Mexico and Yucatan the flowers are irregularly spotted and striped with brownish-purple, and Urban makes of them a new form (forma maculata Urb.; Robinia maculata H. B. K.). According to Preuss, this tree is much used in Nicaragua for shading coffee and cacao. It is also grown for hedges.

Local names: Nicaragua, madre de cacao, madera negra (Preuss); Cuba, bien vestida (Gruner); Mexico, cacaguananchi (Lamb); Carthagena, mata raton or maton (Jacquin). 
34. CORYNELLA DC.

Corynella DC. Ann. Sc. Nat. 4: 33. 1825.

Corynitis Spreng. Syst. 4: Cur. Post. 263. 1827.

Tonotropis Turcz. Bull. Soc. Nat. Mosc. 19²: 506. 1846.

Calyx teeth very short or awl-shaped and elongated, the two upper ones connate; standard suborbicular, clawed, reflexed; wings oblong-oblique; keel slightly incurved, longer than the wings and standard; upper stamen free; anthers uniform, with glandular, often colored connective; ovary stipitate, multiovulate; style upwards incrassate; stigma small, slightly capitate; pod oblong, lanceolate, compressed, 2-valved.- Shrubs; leaves paripinnate or imparipinnate; leaflets stipellate; stipules stiff, sometimes spinous; flowers purple, solitary or fascicled at the older nodes of the branches; bracts small; bracteoles wanting.

\section{Corynella paucifolia DC.}

(Urban, 284.)

Shrub 0.5 to 2 meters high; leaflets 3 to 5 -jugate, oblong or obovate-oblong, 1 to 2 em. long, 0.5 to $1 \mathrm{~cm}$. broad, coriaceous, rounded at the apex, often mucronate, cuneate at the base, glabrous; flowers solitary or fascicled along the rachis, blue (Eggers), or blue becoming white, keel violet (Sintenis).

Near Yauco on the sides of Mount Duey; near San German, on a declivity at Lajas Arriba.-Haiti.

The pretty blue flowers of this shrub appear before the leaves.

Local name, retama.

\section{SABINEA DC.}

Sabinea DC. Ann. Sc. Nat. 4: 92.1825.

Calyx membranous, broadly campanulate, truncate, almost entire or shortly dentate; standard wide, suborbicular, erect or reflexed; wings oblong-falcate; keel inflexed, obtuse, as long as or somewhat longer than the wings; upper stamen free, the rest equally long, or 5 longer and farther connate; anthers uniform; ovary stipitate, multiovulate; style filiform, much inflexed, glabrous; stigma small. terminal; pod linear, compressed, continuous within, 2-valved, the valves at length spirally curved; seeds rather flat, ovoid or reniform.-Trees or shrubs; leaves paripinnate; common petiole terminating in a point; leaflets caducous; stipules usually setaceous, caducous; flowers purple, solitary or fascicled, on the older nodes of the branches; bracts small, bracteoles wanting.

KEY TO THE SPECIES.

Keel oblong; stamens subequal; style suberect.

Keel obliquely obovate; 5 pusterior stamens one-half as long as the 5 anterior (all fertile); style and the upper part of the ovary falcateincurved.

1. S. punicea.

2. S. florida.

\section{Sabinea punicea Urb.}

(Urban, 285.)

Probably shrubby; stipules subulate, 3 to $5 \mathrm{~mm}$. long; leaflets 10 to 20 , obovate or sometimes oval, rounded or subrotundate subapiculate at the apex, 9 to 15 (sometimes even 26) $\mathrm{mm}$. long, 5 to 9 (sometimes even 16) mm. wile, glabrous beneath or thinly pilose on the middle nerve, lateral nerves on each side 4 or 5 , densely reticulate; flowers in the axils of the leaves, many, on a shortened branch, pedicels 0.7 to $1.5 \mathrm{~cm}$. long; calyx 5 mm. long, glabrous, minutely dentate; standard subtriangular-orbicular, 
very obtuse at the apex, 17 to $18 \mathrm{~mm}$. long, 13 or $14 \mathrm{~mm}$. wide; wings oblong, erect, rounded at the apex, $17 \mathrm{~mm}$. long, $4 \mathrm{~mm}$. wille; keel petals free above, connate below, $20 \mathrm{~mm}$. long; upper stamen free, the rest connate to the middle, subequal; ovary stipitate; legume linear, 5 to $6 \mathrm{~mm}$. wide.

Flowers and leaves appear at the same time.

Near Mayaguez, on Mount Mesa (230 meters altitude); near Maricao, on the slopes of Mount Alegrillo. Indigenous.

Local name, caracolillo (Sintenis).

2. Sabinea florida (Vahl) DC.

(Urban, 285. )

Shrub 3 to 5 meters high; leaflets 8 to 15-jugate, oblong or elliptical-oblong, 8 to 15 $\mathrm{mm}$. long, 4 to $8 \mathrm{~mm}$. wide, sericeous beneath, often mucronate; calyx $3 \mathrm{~mm}$. long, subentire, turbinate; wings obovate, $1.3 \mathrm{~cm}$. long; keel broad, semiorbicular, 17 to 18 $\mathrm{mm}$. long, 8 to $9 \mathrm{~mm}$. wide; flowers pale lilac or pale violet, axillary, fascicled, blooming before the leaves appear.

Near Bayamon; near Fajarde on Mount Emajagua toward Ceiba; near Yauco on the Duey River not far from Mount Rodadero; near Sabana Grande at the cataract of Estero River; near Cabo Rojo, in thickets on the seashore around Puerto Real; near Quebradillas, and near Manati, in thickets at Rio Arriba Saliente.-Crabb Island (West), St. Thomas, St. John, Dominica (Grisebach).

Local name, retama.

36. CRACCA Benth.

Cracca Bexth.; Oersted, Kjoeb. Vidensk. Meddel. 8. 1853, not L. 1753.

Benthamantha Alef. Bomplandia 10: 264. 1862.

Brittonamra O. Kuntze, Rev. Gen. 1: 164. 1891.

Calyx with subequal subulate-acuminate laciniae; petals subequal; standard orbicular or reniform with reflexed sides; wings oblong-obovate; keel wide, acute or slightly beaked, inflexed; ovary sessile, with numerous seeds; style slightly stiff, inflexed, bearded; stigma capitate; pod linear, compressed, 2-valved, septate, outer surface -with impressed transverse lines; seeds almost square.-Perennials with imparipinnate leaves; leaflets stipellate; flowers yellowish or whitish in axillary racemes.

\section{Cracca caribaea (Jacq.) Benth.a}

(Urban, 285.)

Shrub 0.5 to 2 meters high, sericeous-pubescent (rarely glabrescent); leaflets 7 to 9-jugate, lanceolate-oblong, 1.6 to $2 \mathrm{~cm}$. long, mucronate; racemes peduncled, fewflowered; flowers 1 to $1.2 \mathrm{~cm}$. long, white, stanclard rose-white or sometimes rose colored; caly $\mathrm{x}$ lobes twice as long as the tube, the lowest longer and exceeding half the keel.

Near Cabeza de San Juan, in shady ravines towarl the sea; near Fajardo in coast districts; near Coamo, in meadows between Serillos and Salinas, in the valley of El Fuerte River in rocky places, and in woods near. Mount San Ildefonso; near Peñuelas along roads; near Guanica, in thickets on the lagoons and in forests at Mount Ensenada.Haiti, St. Thomas, St. Croix, St. Martin (Stockholm Herbarium), St. Bartholomew (Euphrasén), Antigua (Grisebach), Guadeloupe, Désirade (Grisebach), Dominica (do.), Martinique, St. Lueia (Grisebach), St. Vincent, Bequia. Central America, Venezuela, Ecuador. 
37. SESBANIA Scop.

Sesbania Scop. Introd. 308. 1777.

Agati Adans. Fam. 2: 326. 1763.

Darwinia Raf. Fl. Ludov. 106. 1817.

Calyx broadly campanulate, truncate or with nearly equal teeth or lobes: standard ovate or orbicular, spreading or reflexed; wings oblong; keel incurved, obtuse, or acuminate, with a long claw; upper stamen free, geniculate near the base, the others united in a sheath, angled near the base; anthers uniform or the 5 alternate some what longer; ovary usually stipitate with numerous seeds; style with a small terminal capitate stigma; pod long-linear, rarely oblong, compressed, terete or tetragonal, or 4-winged, 2-valved or indehiscent, septate; seeds oblong or quadrate.-Herbs or shrubs, rarely arborescent; leaves abruptly pinnate; leaflets very numerous, entire; stipules caducous; flowers often large, sometimes very large, usually yellow, red, variegated, or white, very rarely a dark purple, in short loose axillary racemes; pedicels slender; bracts and bracteoles setaceous.

KEY TO THE SPEC1ES.

Flowers in short few-flowered racemes.

Flowers large, white or carmine-red; petals 8 to $9 \mathrm{~cm}$. 1ong; calyx $2 \mathrm{~cm}$. deep; shrub or tree.

1. S. grandiflora.

Flowers small, a dull yellow, $1.2 \mathrm{~cm}$. long; calyx $3 \mathrm{~mm}$. long; herb.

2. S. sericea.

Flowers in lax, 4 to 12 -flowered racemes.

Flowers orange-colored or yellow; petals $2.25 \mathrm{~cm}$. long; calyx $6 \mathrm{~mm}$. deep; leaves slightly irritable.

3. S. occidentalis.

Flowers bright yellow; petals $1.25 \mathrm{~cm}$. long; calyx $4 \mathrm{~mm}$. deep; leaves not irritable.

4. S. aegyptiaca.

\section{Sesbania grandiflora (I.) Pers. $a$}

(Urban, 286.)

A tall shrub or small tree of very few years' duration; leaflets 10 to 30 -jugate; flowers white or carmine red; legume linear, 30 or more $\mathrm{cm}$. long, nearly $6.5 \mathrm{~mm}$. wide, compressed; seeds separated by spurious dissepiments.

Cultivated and seemingly spontaneous near Bayamon; near Cabo Rojo; at Mayaguez, in a garden.-Cuba (Richard), Jamaica (Grisebach), Haiti, St. Thomas (Eggers), St. Croix, St. John (Eggers), Gaudeloupe, Martinique, St. Vincent. Indigenous perhaps in the East Indies and north Australia. Cultivated in the Tropics everywhere.

S. grandiflora is most noticeable on account of its large and showy red flowers, which . make it one of the most beautiful of the Papilionatae. In India the root, bark, flowers, and the juice of the leaves are used medicinally, while the natives at the tender leaves, pods, and flowers as a vegetable and in curries. Cattle also eat the leaves and tender shoots. The wood is white, soft, and not durable; is, however, used in liengal for posts of native houses and for firewood, and as a support for the pepper vine. This species yields a gum resembling kino, of a garnet red color when fresh, but becoming almost black by exposure to the air.

Local names, gallito, báculo, cresta de gallo.

\section{Sesbania sericea (Willd.) DC.}

(Urban, 286.)

Plant 1 to 3 meters high; stem suffrutescent, unarmed, cylindrical, pubescent; leaflets 12 to 20 -jugate, oblong-linear, 1.6 to $2.4 \mathrm{~cm}$. long, 4 to $6 \mathrm{~mm}$. hroad, blunt or 
retuse-mucronulate, irritable; racemes short, few-flowered, 4 times or more exceeded by the leaves; flowers $1.2 \mathrm{~cm}$. long, of a dull yellow; calyx one-third as lor $g$ as the corolla; teeth subulate; standard dotted with purple; legume 20 to $25 \mathrm{~cm}$. long, compressed, at length biconvex, not torulose, shortly beaked, slightly depressed, tumid on both margins.

Near Guanica in the water of the lagoon; near Mayaguez, along roads in coast districts near Algarrobo and around the fortress; near $\Lambda$ nasco in moist meadows at Hatillo.-Bahama, Jamaica, Haiti, St. Thomas, Antigua (Grisebach), Guadeloupe, Martinique.

\section{Sesbania occidentalis (Willd.) Pers.}

(Urban, 286.)

Undershrub, stem angular, suffrutescent or shrubby, 2 to 3 meters high; leaflets 12 to 20 -jugate, slightly irritable; flowers yellow or orange-colored, with red lines, the standlard dotted with purple; legume 20 to $25 \mathrm{~cm}$. long, 5 to $6 \mathrm{~mm}$. widle, compressed, at length biconvex; seeds separated by spurious dissepiments.

Near Ponce in ditches and in moist localities; near Guanica, in the water of the bay opposite La Plata; near Cabo Rojo around the hacienda Carmelita; near Mayaguez, on the sides of ditches in Cuesta de las Piedras. - Cuba, Haiti, Trinidad (Grisebach). Indigenous in the West Indies.

Although the difference in the size of the leaves and the form of the leaflets between Sesbania occidentalis and $S$. grandiflora is very slight, the lifference in the size of the flowers is very noticeable, those of $S$. grandiflora being at least 5 times as large as those of $S$. occidentalis.

Local name, sesbania.

\section{Sesbania aegyptiaca Pers.}

(Urban, 286.)

An erect, copiously branched, pale green glabrous shrub, 1.5 to 2.5 meters, even 3 meters high; leaves nearly sessile, the unarmed rachis on the upper ones 5. to $10 \mathrm{~cm}$. long; leaflets 10 to 20 -jugate, glabrous, glaucous green, reaching $2.5 \mathrm{~cm}$. in length, 4 $\mathrm{mm}$. broad, blunt with a faint mucro; peduncles 2.5 to $5 \mathrm{~cm}$. long; racemes lax, 6 to 12-flowerer; pedicels spreading, 0.4 to $0.8 \mathrm{~cm}$. long; calyx $0.4 \mathrm{~cm}$. long, glabrous, the teeth very short, deltoid-cuspidate; corolla bright yellow, $1.25 \mathrm{~cm}$. long, the round emarginate standard $1.25 \mathrm{~cm}$. broad, more or less dotted with purple; pod 15 to $20 \mathrm{~cm}$. long, 3 to $4 \mathrm{~mm}$. thick, distinctly torulose, 20 to 30 -seeded, the valves rounded on the back.

Near Coamo between Serillos and Salinas.-Cuba, Jamaica (Grisebach). Southeastern North America, warmer regions of Africa, tropical 1sia, and North Australia.

The woorl of this plant is soft and fibrous but rather close-grained, the weight 75 pounds to the cubic foot. In the Deccan, Sesbania aegyptiaca, is grown to furnish poles as a substitute for bamboo, and it is often utilized while growing to sharle and support the pepper vines and various cucurbitaceous plants. In Assam the soft, pithy stems are platted into mats, portions of them being dyed black before being matted so as to work out a bold pattern. It is, in Bengal, in common use as a herlge plant, for which purpose its very quick growth renders it suitable. The bark is made into rope, according to Brandis. Seeds, root, juice of the bark, leaves, and flowers are used medicinally. The leaves and young branches are cut for fodder.

\section{PICTETIA DC.}

Pictetia DC. Bibl. Univ. Geneve 29: 40. 1825.

Calyx with unequal slender lobes, the two upper ones short and obtuse, the three lower longer and acuminate; petals shortly unguiculate; standard suborbicular; 
wings obliquely oblong, somewhat longer than the obtuse keel; upper stamen free; ovary stipitate, multiovulate; style filiform; stigma terminal, capitate; pod stalked, oblong or widely linear, compressed, without articulations or separating into 1 to 6 oblong, coriaceous, striate ones; seeds oblong or ovoid, somewhat flat.-Shrubs, glabrous; leaves imparipinnate; leaflets 3 to many, spinescent or pungent; stipules often pungent; flowers yellow, in the axils of the leaves, solitary or in slender fewflowered racemes; bracts and bracteoles caducous.

Professor Urban has written a monograph of the West Indian species of this genus, which is nearly related to Ormocarpum. He distinguishes two sections. The first, Racemosae L rb., is characterized by the numerous (15 to 25) leaflets, truncate or usually emarginate at the apex, and by the elongated inflorescence. To this section belong two species: P. obcordata DC. (San Domingo) and P. aculeata (Vahl) Urb. (widely distributed in the West Indies, first described by Vahl as Robinia aculeata). The second, Fasciculatae Urb., has the leaflets fewer (3 to 7 ), linear or obovate, acuminate or rounded at the apex; the inflorescence short with fasciculate flowers. This section comprises also two species: $P$. spinifolia Urb. (occurring in Haiti and San Domingo) and P. marginata Sauv. (found as yet only in Cuba). P. De Candolle, the author of this genus, which is very characteristic of the West Indian Leguminosae, enumerates six species, of which Urban thus admits only four.

\title{
1. Pictetia aculeata (Vahl) Urb. $a$
}

(Urban, 287.)

Shrub 3 to 4 meters higl or tree 10 meters high; petioles 0.7 to $1.5 \mathrm{~cm}$. long; leaflets 15 to 25 , obovate-orbicular, rotundate, or obcordate, truncate or sometimes broadly emarginate at the top, rounded or subtruncate at the base, 0.7 to $2 \mathrm{~cm}$. long and wide; pedicels 25 down to $12 \mathrm{~mm}$. long; flowers yellow; calyx-tube 3 to $4 \mathrm{~mm}$. long; standard 17 to $22 \mathrm{~mm}$. long; pod broadly linear, more or less incurved, 2.5 to $5 \mathrm{~cm}$. long, 5 to 7 $\mathrm{mm}$. wide, with 2 to 6 articulations.

Near Fajardo, in copses on the seashore toward the light-house; between Arroyo and Guayama, along roads; near Coamo, in woods at San Ildefonso; near Peñuelas in woods; at Salinas de Cabo Rojo in forests on the seashore.-Haiti (Jacquin), Vieques (De Candolle), Water Island, St. Thomas, St. John (Eggers), St. Croix (Jacquin), Trinidad (probably cultivated).

Local name, tachuelo. St. Thomas, fustic.

\section{AESCHYNOMENE L.}

\author{
Aeschynomene L. Sp. Pl. 2: 713. 1753. \\ Aedemone Kотschy, Oestr. Bot. Zeitsch, 8: 116. 1858. \\ Herminiera GurL. \& Perr. Fl. Seneg. Tent. 201. pl. 51. 1832.
}

Calyx lobes 5, nearly equal or united into two lips, either entire or the upper one 2-lobed, the lower 3-lobed; petals with short claws; standard orbicular; wings obliquely obovate-oblong, about equal to the standard; keel sometimes obovate, obtuse, nearly straight, sometimes narrow, acute or beaked, and much curved, the petals free or connected by means of little hairs, or connate; stamens usually all united in a sheath more or less split on both the upper and the lower edge, dividing the stamens into 2 bundles of 5 each: anthers reniform; ovary stipitate, with 2 to many ovules; style incurved, the stigma terminal, sometimes subcapitate; pod stipitate, more or less linear, straight, annular, or falcate, smooth or muricate on the flat or slightly convex faces, separating into 2 to many short, flat, usually indehiscent, reticulated articulations.-Procumbent

$a$ For illustrations see Cook and Collins, pls. 42, 43, facing p. 218 (as Pictetia aristata). 
or erect herbs, undershrubs, or shrubs with equally or unequally pimate leaves; stipules membranous or foliaceous, lanceolate or setaceous; flowers seldom large, usually small, sometimes very small, gold-colored or pale yellow, often streaked with purple, fugacious, in axillary or rarely terminal racemes; bracts resembling the stipules in form. Bracteoles usually addressed against the calyx, often caducous.

Leaves 10 to 30 -jugate.

KEY TO THE SPECIES.

Leaflets 1-nerved; stipules semisagittate; flowers whitish in lax few-flowered racemes; peduncle $1.5 \mathrm{~cm}$. long; pod longstipitate, straight, the joints quadrate, rectilinear on the superior, slightly curved on the inferior margin.

1. A. sensitiva.

Leaflets 3-nerved; stipules calcarate; flowers yellow or purple in dense racemes; peduncle very short; pod shortly stipitate, incurved, contracted at the dissepiments, the joints half-round, rectilinear on the superior, rounded on the inferior margin.

Leaves 4 or 5-jugate.

\section{Aeschynomene sensitiva $\mathrm{Sw}$.}

2. A. americana.

3. A. portoricensis.

(Urban, 287.)

Shrubby or suffrutescent, 1 to 4 meters high; stipules 6 to $9 \mathrm{~mm}$. long, semisagittate, caducous; leaves 2 to $10 \mathrm{~cm}$. long; leaflets 15 to 20 -jugate, linear-oblong, 6.5 to $9 \mathrm{~mm}$. long, 2 to $3 \mathrm{~mm}$. wide, glabrous, glaucous, sensitive; flowers 2 to 4 , in very lax racemes; calyx $4 \mathrm{~mm}$. deep, cleft nearly to the base; corolla pale yellow, the standard red-veined outside, not more than $0.6 \mathrm{~mm}$. deep; pod 3.5 to $5 \mathrm{~cm}$. long, $5 \mathrm{~mm}$. wide, 6 to 9 -jointed, the lowest articulation on a pedicel $0.6 \mathrm{~mm}$. long, the upper suture nearly straight, lower deeply indented, the face with a few scattered setae, black.

Near Bayamon, in moist meadows at Pueblo Viejo; near Fajardo in ditches; Sierra de Luquillo, in swampy places half-way to the top of Mount Jimenez; near Aiborrito, in swamps at Buena Vista; near Utuado, on the Rio Grande River at Salto Arriba; near Guanica, in swamps on the lagoon toward La Plata; near Cabo Rojo in swamps; near Mayaguez, on the sides of ditches and on Mount Mesa at 330 meters altitude; near Añasco in moist fields towarl the sea; near Lares, in grassy places at Anones.-Cuba, Haiti, Guadeloupe, Dominica (Swartz, Grisebach), Martinique, St. Lucia (Swartz), St. Vincent, Grenada, Trinidad (Grisebach). Tropical Africa.

A common Imerican plant, extending from the West Indies to Brazil.

A. sensitiva, like the next, seems to be inhabited by ants. The plant can be readily recognized by its semisagittate stipules, and its lax few-flowered racemes.

Local names, yerba rosario, yerba de cienega.

\section{Aeschynomene americana L.}

(Urban, 287.)

Stem herbaceous or suffrutescent, 1 to 2 meters high; leaves 3 to $5 \mathrm{~cm}$. long; leaflets 10 to 30 -jugate, oblong-linear, 7 to $9 \mathrm{~mm}$. long, $2 \mathrm{~mm}$. wicle; flowers pale yellow, sometimes nearly white with dark red lines; calyx $4 \mathrm{~mm}$. long; corolla 8 to $9 \mathrm{~mm}$. long, yellow or purple; pods 2 to $4 \mathrm{~cm}$. long, $5 \mathrm{~mm}$. wide, glabrous.

Near Bayamon in meadows; between Aibonito and Coamo along roads; near Coamo at the river in Farajones; near Maricao on Mount Montoso; near Sabana Grande toward La Plata along roads; near Mayaguez, on the bank of the river and at the base of Mount Mesa; near Añasco in ditches around IIatillo.-Cuba, Jamaica, Haiti, St. Thomas, St. Croix, St. Kitts, Guadeloupe, Dominica, Martinique, St. Vincent, Grenada, Tobago, 
Trinidad (Grisebach). Found in many parts of tropical America, also introduced in the Old World. Frequent as a weed on cultivated land.

The large spurred stipules of 1 . amoricana are used as a dwelling place by ants. By the form of the stipules it can easily be distinguished from 4 . sensitiva. The half-round joints of the pod, rectilinear on the superior, rounded on the inferior margin, are also striking.

Local name, yerba rosario.

\section{Aeschynomene americana villosa (Poir.) [ r rb.}

Flowers orange-colored.

(Urban. 288.)

Near Aibonito, at Algarrobo; near Cayey at 330 meters altitude; near Guanica, on gravelly banks at Barina; near Maricao in pastures; near Mayaguez around the fortress; near Pincon, in rocky places at Barrio del Pueblo; near Aguada, on plains at Piedra Blanca.-Cuba, Martinique.

\section{Aeschynomene portoricensis Urb.}

(Lrban, 288.)

Perennial or undershrub; stipules ovate or lanceolate, 1.5 to $2.5 \mathrm{~mm}$. long; leaflets obovate or oval, rounded at the top, subcordate at the base, 5 to $8 \mathrm{~mm}$. long; inflorescence 10 to $15 \mathrm{~mm}$. long, axillary, simple, 1 or 2-flowered; flowers yellow, $5 \mathrm{~mm}$. long; pedicel 3 to $5 \mathrm{~mm}$. long; calyx $2.5 \mathrm{~mm}$. long; petals subequal; pod 4 to $5 \mathrm{~mm}$. long, stipitate, the articulations 2 to 4 ; seeds subtriangular-ovate, olive-green, smooth, shiny.

Near Maricao; near Manati, in the sand on the shore of Lake Tortuguero.Indigenous.

This is the only one of the Porto Rico Aeschynomenes that has 4 or 5-jugate leaflets.

\section{STYLOSANTHES $S_{W}$.}

Stylosanthes Sw. Prod. Veg. Ind. Occ. 108. 1788.

Calyx with an elongated filiform tube and scarious lobes, the four upper ones connate, the lowest distinct, elongate; petals and stamens inserted at the throat of the tube; standard orbicular or suborbicular, emarginate; wings oblong, free; keel incurved, subrostrate; stamens all connate, in a closed tube, the anthers alternately longer and fixed near the base and shorter and versatile; ovary nearly sessile at the base of the tube, 2 or 3 -ovulate; style long, filiform, after flowering broken at the middle or near the base, the portion that remains becoming decurved: stigma minute and terminal; porl subsessile, compressed, crowned with the persistent curved base of the style, the articulations usually two, sometimes solitary, rugosereticulated.-Pilose, often hirsute-setose, sometimes viscous herbs or undershrubs; leaves pinnate; leaflets 3 , lanceolate to linear; stipules adnate to the petiole except the long, free, subulate apices; flowers yellow, axillary or terminal, in dense spikes or heads.

\section{Stylosanthes hamata (L.) Taub. $a$}

(Urban, 288.)

Stems procumbent or diffuse. from a few rentimeters to 1 meter high; leaffets oblong or oblong-lanceolate, 7 to $17 \mathrm{~mm}$. long, 2 to $6 \mathrm{~mm}$. wide, pointed, glabrescent: flowers yellow, in bracteate spikes $15 \mathrm{~mm}$. long, single or with an aressory striate 
pedicel; legume sessile, 2 or 1-jointed, usually 1 -seeded, mucronate by the uncinate style base.

Near Bayamon in coast districts at Palo Seco; between Aibonito and Coamo on rocks; near Coamo in sunny copses on Juey brook; near Guanica, in rocky coast districts at Caño Gordo; near Salinas de Cabo Rojo in the sandy soil of the seashore.Bahama, Cuba, Jamaica, Cayman (Hitchcock), Haiti, St. Thomas, St. John (Eggers), St. Martin (Stockholm Herbarium), St. Bartholomew (do.), St. Kitts, Antigua (Taubert), Guadeloupe, Désirade, St. Vincent, Bequia (Kew Bull. no. 81, p. 245), Barbados, Grenada. North and South America.

Local name, zarzabacoa cnana.

\title{
41. ARACHIS L.
}

\author{
Arachis L. Sp. Pl. 2: 741. 1753. \\ Mundubi AdANs. Fam. 2: 323. 1763. \\ Arachidna Moench, Meth. 121. 1794.
}

Calyx tube filiform, the lobes membranous, the four upper ones connate, the lowest thin, distinct; petals and stamens inserted into the apex of the tube; standard suborbicular, wings oblong, free; keel incurved, rostrate; stamens all connate in a closed tube, sometimes only 9; anthers alternately longer and shorter, fixed near the base and versatile; ovary subsessile at the base of the tube, 2 or 3 -ovulate, the torus after the flower falls becoming an elongated, deflexed, rigid stalk forcing the fruit into the ground, the apex acute, and after the style falls terminated by a stigma-like callus; style long, filiform; stigma minute, terminal; pod ripening beneath the soil, oblong, reticulated, indehiscent, subtorulose, but not articulated, continuous within; seeds 1 to 3 , irregularly ovoid.-Low, often prostrate herbs; leaves paripinnate; leaflets usually 2 -jugate, rarely one abortive; stipules adnate to the petiole; flowers yellow or whitish, in axillary, solitary, sessile, dense spikes; bracts often auriculate; bracteoles linear.

\section{Arachis hypogaea L.}

(Urban, 289.)

Stems 30 to $60 \mathrm{~cm}$. long, herbaceous, diffuse, the branches clothed especially above with spreading hairs; stipules $2.5 \mathrm{~cm}$. long, the lower half adnate, the points lanceolate; petioles 2.5 to. $35 \mathrm{~cm}$. long, silky; leaflets in two pairs, without a terminal one, obovate, 3 to $5 \mathrm{~cm}$. long by more than half as broad; flowers yellow, axillary, solitary, on long slender pedicels, only the lower ones fertile; pod $2.5 \mathrm{~cm}$. long, $1.2 \mathrm{~cm}$. thick.

Cultivated and seemingly wild near Bayamon; near Yauco, on Mount Duey in maize fields; near Mayaguez.-Cuba (Sagra), Jamaica (Grisebach), St. Thomas (Eggers), St. Croix (do.), St. John (do.), St. Bartholomew (Euphrasén), Antigua (Grisebach), Guadeloupe, Dominica (Grisebach), Martinique, St. Vincent. Cultivated everywhere in the Tropics. It is probably a native of Brazil, to which country the six other species of the genus belong exclusively.

Arachis hypogaca, the peanut, groundnut, goober, Manila nut, is not only found in all tropical countries, but is sometimes cultivated in southern Europe (in Italy, Spain, and France) and is extensively grown in the United States, from Virginia southward. In the United States the seeds are consumed in very large amounts after roasting, being sold on the streets and eaten between meals, while smaller but considerable quantities are used in confectionery and in the form of "peanut butter." In the Old World millions of bushels are utilized for making an oil which is similar to the finest. olive oil and is largely substituted for it. The oil cake is used as food for live stock, and in Spain from it is made, by mixing it with cacao, sugar, and spices, a kind of chocolate, which is the daily food of the poorer people. 
According to Cook and Collins the Porto Rican peanuts are very small in size and not many are grown.

Local name, mani.

42. ZORNIA Ginel.

Zornia GMei. Syst. $2^{2}: 1076,1096.1791$.

Zonama Steud. Nom. ed. 2. 1: 101. 1840.

Calyx tubuliform-campanulate, membranous, the two upper teeth rather long, subconnate, the two lateral ones much shorter, the lowest lanceolate-oblong, almost as long as the upper ones; petals unguiculate; standard suborbicular; wings obliquely obovate or oblong; keel incurved, subrostrate; stamens all connate in a tube; anthers alternately longer and shorter, attached near the base and versatile; ovary sessile, multiovulate; style filiform; stigma small, terminal; pod compressed, the upper suture nearly straight, the lower deeply sinuate, the articulations indehiscent, smooth, or echinate; seeds orbicular or subreniform.-Herbs or suffrutescent; leaves equally pinnate; leaflets 2 or 4 , often punctate; stipules usually foliaceous; flowers solitary, sessile or shortly stipitate, in lax terminal or axillary spikes hidden each by a pair of persistent bracts; bracteoles wanting.

\section{Zornia diphylla (L.) Pers.}

(Urban, 289.)

Herb; stem $30 \mathrm{~cm}$. or more long, slender, herbaceous, glabrous, diffusely branched from the base; stipules lanceolate; petioles 1 to $2 \mathrm{~cm}$. long, the leaflets in a single pair at the apex, lanceolate 2.5 to $3.5 \mathrm{~cm}$. long, 6 to $9 \mathrm{~mm}$. wide, the edge slightly ciliate, the surface glabrous; flowers in lax axillary stalked racemes 5 to $7.5 \mathrm{~cm}$. long, 6 to 8 in number, hidden each by a pair of persistent bracts, which are ovate, rigid, 6 to $9 \mathrm{~mm}$. long, slightly bristly-ciliate; calyx 3 to $4.5 \mathrm{~mm}$. long, scarious; corolla 6 to $9 \mathrm{~mm}$. long, purplish; pod sometimes exceeding the bracts, articulations 2 to 4 , the bristles 1 to 2 $\mathrm{mm}$. long.

Near Bayamon in sandy meadows; near Salinas de Cabo Rojo on the edge of the woods; near Mayaguez, on slopes of Mount Mesa; near Añasco; near Aguada, on plains at Rosario; near Manati, in sandy soil at Campo Alegre around Tortuguero Lake.Cuba, Jamaica, Haiti, St. Thomas, St. Croix (De Candolle), Guadeloupe, Désirade (Grisebach), Dominica (do.), Martinique, St. Lucia, Barbados, Trinidad (Grisebach). This plant is found everywhere in the tropics and subtropics.

Zornia diphylla is stacked by the Foulahs of western Africa for horse provender. It is sometimes used as a remedy against fever.

Local name, zarzabacoa de dos hojas.

\section{DESMODIUM Desv. ${ }^{a}$}

Merbomia Adans. Fam. 2: 509, 575. 1763.

Desmoduum Desv. Journ. Bot. 1: 122. pl. 5. fig. 15. 1813.

Pleurolobus J. St. IHil. Nouv. Bull. Soc. Philom. 3: 192. 1812.

Calyx with campanulate or turbinate short tube, the upper two teeth more or less united, the other three acute or subulate-acuminate; petals sessile or unguiculate; standard oblong, obovate, or suborbicular, ustally narrowed toward the base, seldom obtuse or subcordate above the claw; wings obliquely oblong, adherent to the keel without appendage or by means of a membrane or a tubercle; keel straight, sometimes incurved, obtuse, rarely rostrate; upper stamens free at the base, toward the midlle 
connate with the others; ovary sessile or stipitate; style inflexed; stigma small, terminal, often capitate; pod exserted, sessile, or stipitate, compressed, superior suture straight or like the inferior more or less sinuate, with 1 to many membranous or coriaceous articulations, flat or rarely subturgid, glabrous or more or less hispid, usually indehiscent at maturity and separating from one another, sometimes dehiscing by the inferior suture; seeds 2 to many, ovoid or globose-reniform, compressed.-Herlss or shrubs, sometimes arboreous or scandent; leaves bipinnate; leaflets usually 3 , sometimes only 1 (the terminal), rarely 5 , often rather large, with stipels; stipules often scarious, striate, or connate; flowers small, rose-colored, purple, bluish, or white, in compound rarely simple racemes, terminal, or axillary; occasionally solitary or a few fascicled in the axils; bracts often membranous, subulate, striate, persistent, or caducous; bracteoles distinct and persistent or very small and caducous, often entirely wanting.

\section{KEY TO THE SPECIES,}

Flowers in terminal, short, crowded racemes, or 2 to 4 together in the axils of, or opposite to the leaves.

Flowers in short, crowded racemes, in pairs in the axils of the wide caducous bracts. (Section Nicolsonia.)

1. D. barbatum,

Flowers 2 to 4 together on long filiform pedicels in the axils of the leaves or opposite to them, more rarely in fewflowered terminal racemes, when they are solitary in the axils of the bracts. (Section Sagotia.)

Flowers in lax, usually elongated, racemes or panicles.

Upper suture of the pod straight, the lower deeply indented; pod indehiscent. (Section Heteroloma.)

Bracts rather large and wide, before florescence imbricate.

Bracts small, inconspicuous.

Stipules more or less connate at the base.

Articulations of the pod 2; stipe longer than the calyx.

Articulations of the porl numerous; stipe shorter than the calyx.

Stipules usually free, only the younger ones

slightly connate.

Stipules cordate.

Stipules oblong-lanceolate or lanceolate.

Both sutures of the pod deeply indented, indehiscent. (Section Chalakium.)

Pod strongly constricted, more or less tortuous.

Pod with 2 articulations, superior one enlarged, fertile.

Pod with many equal articulations.

Perennial, erect; stipules oblique-subulate; pod tortuous, at length flattened; articulations obicular, flat.

Annual flaceid, at length subscandent, rooting at the base; pod very tortuous and lasting so; articulations rhomboid-orbicular.

3. D. ascendens.

4. D. axillare.

5. D. sиропит.

6. D. albiflorum.

7. I. uydlerianum.

8. I. molle.

9. D. tortuosum.

10. D. spirale.

Pod slightly constricted at the dissepiments, not tortuous; articulations oval-linear.

11. 1). scorpiurus. 
1. Desmodium barbatum (L.) Benth.

(Urban, 290.)

Suffrutescent, erect, or ascending, 30 to $60 \mathrm{~cm}$. high; leaflets 3 , elliptical-oblong, obovate, or elliptical-lanceolate, 1 to $1.5 \mathrm{~cm}$. long, 4 to $7 \mathrm{~mm}$. wide, above glabrous or subpilose, beneath appressed-villose; calyx $4.4 \mathrm{~mm}$. deep, at length nodding, very long brown-pilose, the teeth lanceolate-setaceous, the tube very short; corolla light blue or purple, about as long as the calyx; legume 1 to $1.5 \mathrm{~cm}$. long, $2 \mathrm{~mm}$. wide, indehiscent, the upper suture straight, the lower somewhat indented, reflexed, 2 to 4-jointed.

Near Bayamon, in sandy places; near Lares, in ravines at Espino; near Cabo Rojo, on hills toward Joyuda; near Mayaguez, on the slopes of Mount Mesa; near Aguada, in rocky districts at Rosario; near Manati, on plains at Garrochales.-Cuba (Grisebach), Jamaica, Haiti, Martinique, St. Lucia, Tobago, Trinidad. In tropical America, a common plant, in pastures, and on the roadside. Also introduced into the old World.

The short, many-flowered racemes and the deep, densely plumose calyx make this common plant of the Tropics easily recoginzed.

Local name, zarzabacoa peluda.

\section{Desmodium triflorum (L.) DC.a}

Urban, 289.

Stem widely creeping, copisusly and diffusely branched, forming a dense matted cluster, the branches slender, glabrous or thinly clothed with fine spreading silky hairs; stipules lanceolate, acuminate, $4.4 \mathrm{~mm}$. deep; leaflets 3 , broadly obovate, terminal one 8.5 to $11 \mathrm{~mm}$. long and nearly as broad, lateral ones smaller, both sides glabrous or subglabrous; flowers blue (Urban); calyx $4 \mathrm{~mm}$. deep, silky, teeth reaching more than halfway down; corolla reddish or white (Oliver), fragrant, about equaling the calyx; pod 1.1 to $1.7 \mathrm{~cm}$. long, $4 \mathrm{~mm}$. wide, the lower suture waved one-third of the way down; articulations 4 to 6 , the faces subglabrous.

Near Naguabo in fields around Hacienda Oriente; near Cayey along roads toward Cidra; near Coamo, in the valley of El Tendal River on grassy slopes; near Cabo Rojo on hills toward Joyuda; near Rincon in meadows at Barrio del Pisblo.-Cuba, Jamaica, Cayman, Haiti, St. Thomas, St. Croix, St. John (Eggers), St. Bartholomew (Stockholm Herbarium), St. Kitts, Antigua (Grisebach), Guadeloupe, Martinique, St. Vincent, Barbados, Grenada, Trinidad. Mexico to Brazil, tropical Africa, East Indies.

Desmodium triflorum is a common weed of the Tropics. The fresh leaves are used medicinally. In India Roxburgh says that this is very common on pasture grounds and helps to form the most beautiful turf; further, that cattle are very fond of it. II üller recommends its cultivation in regions too hot for elover. Inother author says that in India it springs up on all soils, supplying there the place of Trifolium and Medicago.

Local name, zarzabacoa de tres flores.

\section{Desmodium adscendens (Sw.) DC:}

(Urban, 290.)

An undershrub 1 to 1.3 meters high, with ascending woody branches; leafiets 3 , obovate, 1.8 to $2.5 \mathrm{~cm}$. long, sometimes nearly as broad as deep, the apex rounded, subcoriaceous, upper surface glabrous, lower finely adpressed-silky; racemes often 15

$a$ For illustration see Cook and Collins, fig. 12, p. 189 (as Meibomia triflora). 
cm. long; bracts ovate, cuspidate, equaling the slender pedicels, 8.8 to $13 \mathrm{~mm}$. long, spreading ultimately from the rachis at right angles; calyx $6 \mathrm{~mm}$. deep, teeth linear, reaching down nearly to the base; corolla purple or reddish, rarely white, twice as long as the calyx; pod 1.2 to $2 \mathrm{~cm}$. long, $2.2 \mathrm{~mm}$. broad, joints 3 to 6 , the lower suture waved halfway down.

Near Bayamon in moist sandy soil at Cataño; Sierra de Luquillo halfway to the top of Mount Jimenez in woods; Sierra de Naguabo, near Minas de Cobre at Rio Blanco; near Los Mameyes; near Juncos on roadsides; near Hato Grande on Mount Gregorio; between Aguas Buenas and Caguas along roads; between Caguas and Cayey along roads; near Cayey at Quebrada Arriba; near Aibonito along roads; near Adjuntas, on the declivities of Mount Andubo and on Mount Cedro; near Maricao; near Mayaguez, on declivities of Mount Mesa.-Cuba (Grisebach), Jamaica, Haiti, St. Kitts (Grisebach), Antigua (do.), Guadeloupe, Dominica, Martinique, St. Vincent, Grenada, Tobago, Trinidad (Grisebach). This is a common American species, but in the Old World is only known in Africa.

Local name, zarzabacoa galana.

\section{Desmodium axillare (Sw.) DC.}

The Porto Rican material is included in the following varieties and form:

\section{4a. Desmodium axillare obtusifoliola (Kuntze) Urb.}

(Urban, 291.)

Herbaceous, rarely suffrutescent, creeping, rooting, 30 to $45 \mathrm{~cm}$. long, elothed with very short soft inconspicuous hairs intermixed with hamate ones; leaflets 3 , rhomboid, ovate-rhomboid or orbicular-rhomboid, 3.5 to $5.5 \mathrm{~cm}$. long, 2.5 to $4.5 \mathrm{~cm}$. wide, obtuse or rounded at the apex; flowers rose-colored, dark rose-colored, or reddish-violet, about $5 \mathrm{~mm}$. long, the pedicel 6.5 to $13 \mathrm{~mm}$. long; legume long-stipitate, the suture slightly notched, the dorsal margin sinuate as deep as to the ventral suture; articulations deltoid-semioval, 7 to $8 \mathrm{~mm}$. long, 4 to $5 \mathrm{~mm}$ wide.

Near Bayamon in shady places; Sierra de Luquillo in woods halfway to the top of Mount Jimenez; near Los Mameyes in moist localities among herbs; near Cayey, in a thicket of Coffea arabica at Pedro Avila; near Adjuntas, in woods on Mount La Vaca.Cuba, Jamaica, Haiti, St. Kitts, Guadeloupe, Dominica, St. Vincent, Grenada, Costa Rica, Venezuela, Colombia, Chile.

This plant is extremely common in shady places in Porto Rico.

Local name, zarzabacoa de monte.

\section{4b. Desmodium axillare acutifolium (Kuntze) Urb.}

(Urban, 292.)

Stem densely clothed with long, soft hairs intermixed with short, often very inconspicuous, hamate ones; leaflets ovate or ovate-elliptical, acuminate; flowers pale purple; articulations of the pod 6 to $8 \mathrm{~mm}$. long, 4 to $5 \mathrm{~mm}$. wide.

Near Bayamon in the woods at Pueblo Viejo, near Juncos on Mount Santo de Leon.Cuba, Jamaica, Martinique, St. Vincent, Trinidad, Guiana, and Brazil.

\section{4c. Desmodium axillare forma robustius Urb.}

$$
\text { (Irban, 292.) }
$$

The stem thicker than in variety angustatum, $3 \mathrm{~mm}$. thick and densely hirsute; terminal leaflet $12 \mathrm{~cm}$. long; flowers rather longer than in variety angustatum; wings 5 $\mathrm{mm}$. long; pod articulations $10 \mathrm{~mm}$. long, $6 \mathrm{~mm}$. wide; calyx red-brown; petals pale rose-colored; stamens rose-colored; anthers pale yellow (ex Sintenis).

Sierra de Luquillo, in woods halfway to the top of Mount Jimenez. 


\section{4d. Desmodium axillare sintenisii Urb.}

(Urban, 292.)

Pubescence of the stem very short; leaflets ovate, long-acuminate; flowers white; porl articulations 9 to $10 \mathrm{~mm}$. long, 6.5 to $7 \mathrm{~mm}$. wide.

Sierra de Luquillo, halfway to the top of Mount Jimenez; Sierra de Yabucoa, in the primeval forests of Mount Cerro Gordo and Mount Sombrero.-Haiti.

\section{Desmodium supinum ( $\mathrm{S}_{W}$.) DC.}

(Urban, 290.)

A diffuse undershrub 60 to $90 \mathrm{~cm}$. high, branches finely gray-pubescent upwarl; stipules connate to the middle, at length subdistinct, lanceolate, scarious; leaflets 3 , central one oblong or obovate, 7.5 to $10 \mathrm{~cm}$. long, generally under half as broad, its petioluleshort, its stipellae minute; lateral leaflets smaller and more rounded at the base, subcoriaceous, the upper surface glabrous, the lower thinly and finely pubescent; calyx $2.2 \mathrm{~mm}$. deep, the teeth lanceolate, reaching halfway down; corolla red, becoming blue or pale purple, 6.5 to $8.5 \mathrm{~mm}$. deep; pod $2.5 \mathrm{~cm}$. long, $3 \mathrm{~mm}$. wide, with 5 to 8 articulations, which are considerably longer than broad.

Near Bayamon in grassy places; near Fajardo along roads and in the river valley toward the mountains; near Juncos along roads; near Maunabo at Punta Tuna; near Cayey at Quebrada Arriba in thickets; near Cabo Rojo along roads around Puerto Real; near Mayaguez.--Bahama, Cuba, Jamaica, Cayman (Hitchcock), Haiti, St. Thomas, St. Croix, St. John, St. Martin (Stockholm Herbarium), St. Bartholomew (do.), St. Kitts, Antigua, Guadeloupe, Dominica, Martinique, St. Vincent, Bequia (Kew Bull. no. 81, p. 245), Barbados, Grenada, Tobago, Trinidad (Grisebach), Margarita.

A common tropical American species, occurring also in Africa and the Mauritius.

Local name, zarzabacoa.

\section{5a. Desmodium supinum angustifolium (Griseb.) Urb.}

(Urban, 291.)

Plant 1 to 1.5 meters high; flowers conspicuous, pale blood-red or pale purple.

Between Aibonito and Coamo, near Algarrobo, in thickets; near Coamo, in the valley of El Tendal River; near Rincon, on shady mountains at Barrio del Pueblo.-Cuba, Haiti, Antigua (Grisebach).

\section{Desmodium albiflorum Salzm.}

(Urban, 292.)

Stem diff $:$ se, 15 to $30 \mathrm{~cm}$. high; leaves sometimes widely, sometimes narrowly ovate, about $2.5 \mathrm{~mm}$. long, obtuse or rarely somewhat acute, membranous; stipules cordate, acuminate, free or at the back connate; flowers white; calyx about $2.2 \mathrm{~mm}$. deep, petals $6.5 \mathrm{~nm}$. long; pod subsessile, its articulations indefinite in number, usually 5 or 6 , these when mature $6.5 \mathrm{~mm}$. long, $4.4 \mathrm{~mm}$. wide.

Near Cayey, in coffee plantations at Pedro Avila; near Coamo, in coffee plantations at Farrajones.-Mexico, Central America, Ecuador, and Brazil (Bentham, Hemsley).

\section{Desmodium wydlerianum Urb.}

(Urhan, 292.)

Perennial (?), procumbent below, rooting at the nodes, ascending above, shortly pubescent; leaflets triangular-ovate or rhomboid, acuminate, subtruncate at the base, 
3 to $6 \mathrm{~cm}$. long, 3 to $5 \mathrm{~cm}$. wide, above shortly pilose, beneath subglabrous; inflorescence 10 to $15 \mathrm{~cm}$. long; calyx about $2 \mathrm{~mm}$. long; flowers violet; standard suborbicular or orbicular-ovate, $4 \mathrm{~mm}$. long; stamens 9; pod (immature) with 2 or 3 articulations.

Eastern part of the island (Schwanecke, Wydler).-Grenada, Tobago.

\section{Desmodium molle (Vahl) DC.}

(Urban, 292.)

Erect; stem shrubby; branches herbaceous, striate, 1.3 to 2 meters high; leaflets 3 , ovate, 4 to $5 \mathrm{~cm}$. long, 1.25 to $2.75 \mathrm{~cm}$. wide, membranaceous, pubescent on both sides; stipules subulate-setaceous; flowers very small, $3.3 \mathrm{~mm}$. long, greenish outside, dark blue within; calyx segments linear, long; pod membranaceous, flat; articulations at first elliptical, reniform with a lateral notch when mature, 6.5 to $8.5 \mathrm{~mm}$. long, 4.4 to $5 \mathrm{~mm}$. wide.

Near Coamo in meadows between Serillos and Salinas: near Juana Diaz, along roads about Escalabrado; near Guanica, on declivities at Punta de la Meseta and in thickets at Montalba.-Jamaica (Grisebach), Haiti, St. Thomas, St. Croix (Vahl), Martinique, Curaçao, Central America, South America.

The legume of $D$. molle is quite unlike that of any other Porto Rican Desmodium. It has a pod with 2 elliptical articulations, of which the upper is enlarged and fertile, and when mature has a lateral notch. This is the only pod with a reniform articulation within this genus in Porto Rico.

\section{Desmodium tortuosum (Sw.) DC.}

(Urban, 293.)

Erect, 0.5 to 1.5 meters high; stem striate, cylindrieal, the down uncinate; leaflets 3 , ovate or ovate-oblong, the terminal one 2.5 to $10 \mathrm{~cm}$. long, 1 to $4.5 \mathrm{~cm}$. wide, hispidulous or glabrescent; pedicels filiform, longer than the flower; flowers small, purple or pale blue; calyx 2 to $3 \mathrm{~mm}$. deep; corolla 5 to $6 \mathrm{~mm}$. long; pods with 2 to 6 articulations, constricted nearly to the center.

Near Bayamon, in shady localities and along roads toward Toa Baja; near Fajardo in cultivated places; near Maunabo on shady slopes between Emajagua and Punta del Naranjo; between Aibonito and Algarrobo in steep places at the roadside; near Barranquitas, on declivities at Isabon; between Aibonito and Coamo along roads; near Coamo, at Salinas; near Juana Diaz along roads; near Peñuelas on the top of Mount Vi and on plains around Mount Llano; near Guanica on gravelly hanks around Barinas; near Mayaguez; near Rincon, in the mountains at Calvache and on the plains toward Aguada.-Cuba, Jamaica, St. Thomas, St. Croix, Guadeloupe, Dominica, Martinique, St. Vincent, Bequia (Kew Bull. no. 81, p. 246), Mustique (dó.), Grenada, Central America, North America, South America.

Local name, zarzabacoa, junquillo.

\section{Desmodium spirale (Sw.) DC.}

(Urban, 293.)

Stems annual, 30 to $45 \mathrm{~cm}$. high, slender, diffuse, slightly pubescent; petioles 1.2 to $2.5 \mathrm{~cm}$. long; leaflets 3 , the terminal one roundish or orate, 2.5 to $5 \mathrm{~cm}$. long; 1.2 to 2.5 (m. broad, the lateral ones smaller, subpapyraceous, both sides green, glabrous: pedicels 6.5 to $8.5 \mathrm{~mm}$. long, spreading, very slender, glabrous; flowers in Porto Riean specimens always white; calyx $2.2 \mathrm{~mm}$. long, deeply cleft; corolla slightly exceeding the calyx, greenish variegated with purple; pod 9 to $12 \mathrm{~mm}$. long. $2.2 \mathrm{~mm}$. wide; articulations 4 to 6 , separated by very narrow spaces, often spirally twisted. 
Near Bayamon; near Aibonito, at ('ari-Blanco; near Coamo, in the valley of El Fuerte River, in meadows around Serillos at Salinas, and on grassy declivities toward Aibonito; near Juana Diaz, along roads around Escalabrado; near Peñuelas in the rocky plains at Tallaboa Alta; near Mayaguez; near Rincon, in plains at Rarrio del Pueblo.-Cuba, Jamaica, St. Thomas, St. Croix (Eggers), St. John (Eggers). Antigua ( (irisebach), Guadeloupe, Martinique (Duss), St. Vincent, Union (Kew Bull. no. 81, p. 245), Barbados, Trinidad (Grisebach). Common in tropical America; found also in the East Indies, Africa, and the Polynesian Islands.

Local name, zarzabacoa espiral.

\section{Desmodium scorpiurus (Sw.) Desv.}

(Ưrban, 293.)

Procumbent, rooting at the base; stem angular; leaflets 3 , oval or oblong, 1.5 to 4 $\mathrm{cm}$. long, 1 to $1.5 \mathrm{~cm}$. wide, rounded at the apex, clothed on both surfaces with long, silky, appressed hairs; calyx 2.5 to $3 \mathrm{~mm}$. deep, deeply cleft; corolla slightly exceeding the calyx, peach-colored, rose, or purple, becoming white; pod subsessile, uncinate-pubescent, slightly constricted at the dissepiments, the joints 2 to 7 , ovallinear, minutely truncate at both ends, the terminal pointed.

In Bayamon around the church; near the town in fields; near Fajardo in cultivated places; between Aibonito and Algarrobo on precipices near the roads; between Aibonito and Coamo on declivities; near Coamo, on Mount Santana and in the valley of El Fuerte River; near Utuado, in ravines at San Andres; near Cabo Rojo, orr hills toward Joyuda.-Cuba, Jamaica, Haiti, St. Thomas (Grisebach), St. ('roix (Eggers), Antigua (Grisebach), Guadeloupe, Dominica (Grisebach), Martinique, St. Vincent, Grenada, Trinidad, Margarita.-Mexico, Central America, Ecuador, Peru.

A plant common in pastures.

Local name, zarzabacoa cola de escorpion.

44. ALYSICARPUS Neck.

Alysicarpus Neck. Elem. 3: 15. 1790.

Fabricia Scop. Introd. 307. 1777, not Adans. 1763.

Hegetschweilera Heer \& Regel, Cat. Sem. Hort. Turic. 1842; Bot. Zeit. 1: 47. 1843.

Calyx deeply cleft, the lobes stiff and dry, striate, subequal, the two upper ones connate almost to the apex; standard orbicular or obovate, narrowed into a claw; wings obliquely oblong, adherent to the keel; keel obtuse, slightly incurved, usually witl a little membrane on the outside on both margins; upper stamen free; ovary sessile or substipitate, multiovulate; style filiform, inflexed upwards; stigma terminal, sometimes oblique, usually broadly capitate; pod terete or somewhat compressed, equal or constricted between the articulations, these roundish or truncate at the ends and indehiscent; seeds ovate or orbicular.-Erect or diffuse herbs, glabrous or loosely hairy; leaves simple in our species (or very rarely 3 -foliate); stipules membranous, scarious, acuminate, free or connate; flowers small, in terminal or rarely axillary racemes, the pedicels usually in pairs; bracts and bracteoles usually scarious, caducous.

\section{Alysicarpus nummularifolius (L.) DC. ${ }^{a}$}

(Urban, 294.)

A perennial, tufted or much branched at the base, the stems decumbent or ascending, from a few centimeters to $25 \mathrm{~cm}$. long, glabrous or slightly pubescent; leaves on short slender petioles, the lower ones cordate-orbicular or oval, not $1.2 \mathrm{~cm}$. long, the

a Cook and Collins, p. 74, as .1lysicarpus vaginalis.

$25734-$ VOL 10 , PT $4-07-5$ 
upper ones from oval-oblong to lanceolate-linear, and often $2.5 \mathrm{~cm}$. long or more, all obtuse; calyx about $4.4 \mathrm{~mm}$. long, the lobes very narrow, ending in a subulate almost hair-like point, the two upper ones less united than in most species; petals pale purple, becoming blue, scarcely exceeding the calyx; pod often $1.8 \mathrm{~cm}$. long or rather more, obscurely wrinkled, the separation of the articulations marked by transverse raised lines, without any or rarely with a slight contraction.

Seemingly spontaneous near Bayamon in coast districts at Palo Seco; near Fajardo in rocky localities toward Ceiba; near Peñuelas, in rocky districts at Tallaboa Alta; near Cabo Rojo, in grassy places at the base of Mount Buenavista.-Jamaica, Haiti, St. Thomas, St. ('roix, St. John, St. Kitts (Grisebach), St. Martin (Stockholm Herbarium), St. Bartholomew (do.), Antigua (Grisebach), Guadeloupe, Martinique, St. Vincent, Bequia (Kew Bull. no. 81, p. 246), Barbados, Grenada, Tobago, Trinidad. A common weed in the tropics of the old World and introduced into America.

Local name, yerba de contrabando.

\section{DALBERGIA L. f.}

\section{Dalbergia L. f. Suppl. 52, 316. 1781.}

Calyx with the two upper teeth broader and the lowest rather longer than the others; standard broadly ovate or orbicular; wings oblong; keel slightly incurved, obtuse, its petals connate on the back at the apex; stamens all connate in a sheath slit above, or the upper one free or absent, or the sheath also slit below or the lowest sometimes also free; anthers small, erect, the cells dehiscing by a small apical slit; ovary stalked, biovulate; style almost straight; stigma small, terminal; pod orbicular or broally oblong, flat or corky, indehiscent, 1-seeded, subemarginate at the upper suture.-Loosely branched or sarmentose shrubs; leaves imparipinnate; leaflets usually alternate, many or rarely reduced to 1 ; flowers in small panicles in the axils of the leaves.

\section{KEY TO THE SPECIES.}

Leaflets solitary, pale and tomentose beneath, rarely glabrescent, ovate, obtuse, acuminate; stamens 10; pod orbicular, 2.5 to $3 \mathrm{~cm}$. in diameter, thick, subligneous.

Leaflets 3 to 5 , both sides glabrous, or with a few scattered hairs beneath, ovate, acuminate; stamens 9 ; pod roundish, oblong, blunt at both ends, 2.5 to $3 \mathrm{~cm}$. long, $2 \mathrm{~cm}$. wide, flat, shining, not much thickened, subligneous.

\section{D. hecastophyllum.}

\section{Dalbergia hecastophyllum (L.) Taub.}

\section{(Urban, 294.)}

Shrub 2 to 3 meters high or tree 6 to 8 meters high, with firm woody branches; leaves unifoliolate, rarely bifoliolate; leaflets 7 to $10 \mathrm{~cm}$. long, 4.5 to $5 \mathrm{~cm}$. wide; petiole 1 cm. long; flowers in small cymose panicles, 2.5 to $5 \mathrm{~cm}$. long, axillary; calyx campanulate, $5 \mathrm{~mm}$. deep; corolla white, more than twice as long as the calyx.

Near San Juan, in thickets near the sea at Cangrejos; near Yabucoa in coast districts; near Ponce, in littoral thickets at Peñon; in coast districts near Mayaguez at Algarrobo; near Rincon; near Quebradillas.-South Florida (variety psilocaly. Radlk.), Cuba, Jamaica, Cayman (Hitchcock), Haiti, St. Thomas, St. Croix (Grisebach, Eggers), St. John, Antigua (Grisebach), Guadeloupe, Dominica (Grisebach), Martinique, st. Vincent, Bequia, Barabdos, Grenada, Tobago, Trinidad (Grisebach). Tropical America, especially near the sea, from south Brazil to Florida and Central America; also in west tropical Africa. 
Dalbergia hecastophyllum (L.) Taub., a plant common in maritime thickets, has solitary leaflets, 10 stamens, and a pod that is nearly round, while the only other Porto Rican species, D. monetaria, has 3 to 5 leaflets, 9 stamens, and an oblong pod.

Local names, maray-maray, palo de pollo.

\section{Dalbergia monetaria L. f.}

(Urban, 295.)

Shrub 2 to 4 meters high; stems firm, woody, wide climbing; leaves 15 to $17 \mathrm{~cm}$. long; leaflets 8 to $13 \mathrm{~cm}$. long, 4 to $5.5 \mathrm{~cm}$. wide; flowers in small panicles in the axils of the leaves, 1.5 to $3 \mathrm{~cm}$. long; calyx $5 \mathrm{~mm}$. deep, green; corolla more than twice as long as the calyx, white or yellow-white; anthers yellow, becoming brown; mature fruit brown.

Near Bayamon in mountain thickets and woods; Sierra de Luquillo, in the woods between Mavi and Mount Jimenez; near Juncos on the river bank; near Hato Grande, on the shady river bank opposite Mount Gregorio; near Yabucoa, on the edge of the forests at Jacana, in primeval forests at Guayavota, and in La Pandura at Santa Elena; near Aibonito; near Utuado, on the edge of the primeval forest at San Andres and in copses on the Rio Grande River at Saltillo Arriba; near Naricao in mountain woods; near Sabana Grande in the woods near the cataract of Estero River; near Mayaguez.Cuba (Grisebach), Haiti, Guadeloupe, Martinique, St. Vincent, Grenada, Trinidad. Tropical America, north Brazil, Cayenne, Surinam, British Guiana.

Local names, palo de brasilete, membrillo.

46. DREPANOCARPUS G. F. W. Mey.

Drepanoearpus G. F. W. Mey. Prim. Fl. Esseq. 236. 1818.

Nephrosis Rich.; DC. Prod. 2: 420.1825.

Orucaria Juss.; DC. loc. cit.

Calyx campanulate, obtuse at the base, truncate at the apex, the teeth short; standard broadly ovate or orbicular, on the outside silky; wings oblong, often falcate; keel incurved, its petals connate at the back; stamens all connate in a sheath slit above, or both above and below, or more rarely the upper one free; ovary shortstalked, 1- (rarely 2-) ovulate; style slender, incurved; stigma small, terminal: pod falcate or suborbicular, compressed, thick-leathery, the upper suture intruse, the lower very much arched, with 1 large, reniform, compressed seed.-Erect tree or highclimbing shrub; leaves imparipinnate; leaflets usually alternate; stipules often spinous; flowers small or moderately large, purple, violet, or white; racemes short, fascicled or branched, axillary or in terminal panicles; bracts small, caducous; bracteoles under the calyx orbicular, persistent.

1. Drepanocarpus lunatus (L. f.) (., F. W. Mey.

(Urban, 296.)

An erect bush or small tree 2 to 3 meters high, with firm glabrous branches and with sharp, subfalcate spines from the nodes; petioles short; rachis 5 to $10 \mathrm{~cm}$. long; leaflets 5 to 11 , short-stalked, oblanceolate or oblong, 3.5 to $5 \mathrm{~cm}$. long, blunt, rigidly coriaceous, both sides glabrous, the veins slightly raised; panicles copious, axillary and terminal; calyx glabrous, $6 \mathrm{~mm}$. deep; corolla lilac, 6.5 to $8.5 \mathrm{~mm}$. deep; pod $1.8 \mathrm{~cm}$. broad, curved round so that the point touches the base, subligenous, the curve 3 to $3.5 \mathrm{~cm}$. broad; pedicel $6 \mathrm{~mm}$. long.

Near Bayamon, in the forest at Palo Seco; near Los Mameyes, in the Manglar swamp at La Carmelita; near Humacao, in littoral thickets near Punta ('andcka; near Maunabo, in thickets at Punta de Tuna; near Mayaguez.- Haiti, St. Thomas, St. Croix 
(Eggers), Guadeloupe, Martinique, St. Lucia (Grisebach), St. Vincent (do.). Tropical America and western Africa.

This plant grows chiefly near the seashore and is noticeable on account of its short, sharply recurved spines and its pod, which is so bent that the point touches the base.

Local names, palo de hoz, escambron.

\section{PTEROCARPUS L.}

Pterocarpus L. Sp. Pl. ed. 2. 2: 1662. 1763.

Moutouchi Aubl. Pl. Gui. 2: 748. pl. 299. 1775.

Moutouchia Benth. Ann. Wien Mus. 2: 94. 1838.

Calyx campanulate, often incurved, narrowed at the base, the two upper teeth more or less connate; standard broadly ovate or suborbicular; wings obliquely obovate or oblong; keel with its petals resembling or shorter than the wings, free or shortly connate on the back; stamens all connate in a sheath slit above or both above and below, or the upper one free; ovary sessile or stipitate, 2 to 6 -ovulate; style filiform, slightly incurved; stigma small, terminal; pod compressed, indehiscent, orbicular or broadly ovate, more or less oblique, the style lateral or terminal, seminiferous in the center and there more or less incrassated, with a wing round the border; seeds 1 or 2, oblong or subreniform, if 2 separated by a hard septum.-Trees; leaves imparipinnate, leaflets alternate or almost opposite; flowers usually showy, yellow, rarely white or violet, in terminal or axillary, simple or compound racemes; bracts and bracteoles small, caducous.

\section{Pterocarpus officinalis Jacq. ${ }^{\alpha}$}

(ITrban, 296.)

Trees 25 to 30 meter high; leaflets 5 to 9 , alternate, ovate or oblong, acuminate, shiny, 5 to $10 \mathrm{~cm}$. long, 3 to $5.2 \mathrm{~cm}$. wide, the veins on both sides conspicuous, subcoriaceous, glabrous, the petioliules $6 \mathrm{~mm}$. long; flowers in compound racemes, yellow; calyx strongly oblique, 4 to $5 \mathrm{~mm}$. deep, turning black in drying; corolla $1.3 \mathrm{~cm}$. long; standard violet-colored on the edge, at the middle; pod glabrous, stipitate, corky-rugose, with a very oblique axis, 1-seeded, surrounded by a narrow wing, which is less distinct on the carinal edge, 3 to $5 \mathrm{~cm}$. in diameter; wing 6.5 to $8.5 \mathrm{~mm}$. broad on vexillar edge.

Near Bayamon in swampy localities; Sierra de Luquillo, in the woods of Mount Jimenez; near Mayaguez.-Jamaica (Grisebach), Guadeloupe, Dominica, St. Lucia, St. Vincent, Trinidad. Tropical America, Central America.

From Pterocarpus officinalis, the only species found in Porto Rico, is obtained a kind of kino known as "American dragon's blood." The tree is tapped and the sap collected, which when dried in the sun forms a hard mass that is used in medicine as an astringent and in tanning and dyeing. Large pieces of the substance are dark red, while smaller pieces are transparent.

Local name, palo de pollo.

48. LONCHOCARPUS H. B. K.

Lonchocarpus H. B. K. Nov. Gen. \& Sp. 6: 383. 1823.

Sphinctolobium Vog. Linnaea 11: 417. 1837.

Neuroscapha Tul. Ann. Sc. Nat. II. 20: 137. 1843.

Calyx often cupuliform, truncate, the teeth very short or wanting; standard orbicular, obovate, more rarely oblong, with 2 auricles at the base above the claw; wings obliquely oblong or falcate, slightly adhering to the keel above the claw; keel arcuate

a Cook and Collins, p. 226, as Pterocarpus draco. 
or nearly straight, the obtuse petals slightly cohering along the back; upper stamen free at the base, sometimes united with the others in a closed tube; ovary more or less stalked, biovulate or multiovulate; style filiform; stigma small, terminal: pod oblong or elongated, membranous or coriaceous, flat, indehiscent, the style scar terminal, persistent, sutures not winged but the upper sometimes laterally dilated; seeds 1 or 2 , rarely more, flat, almost reniform or orbicular. Trees or woody climbers; leaves irriparipinnate; leaflets opposite, rarely with stipels; stipules small, narrow; flowers violet, purple, or white, in simple racemes or raceme-like panicles, usually in pairs or clusters along the rachis; bracts and bracteoles usually small, deciduous, more rarely persistent.

KEY TO THE SPECIES.

Flowers usually in pairs along the rachis; leaflets glabrous; standard usually sericeous on the outer surface; pod oblong or linear, the upper suture, especially near the seeds, with a projecting ridge; flowers rose-colored.

Standard callous or auriculate at the base; leaflets 7 to 11 .

(Section Neuroscaphi Benth.)

1. L. domingensis:

Standard not callous or auriculate at the base; leaflets 5 or 7 .

2. L. glancifolius.

Flowers many, usually small; standard glabrous or thinly silky on the outer surface; sutures of the porl not dilated or thickened. (Section Dexsiflori Benth.)

3. L. latifolius.

\section{Lonchocarpus domingensis (Pers.) DC.}

( $(T r b a n, 296$.

Tree 15 meters high, young branches brown-tomentose becoming glabrous; leaves 17 to $19 \mathrm{~cm}$. long; petiole about $3 \mathrm{~cm}$. long; leaflets 7 to 11 , most frequently 7 , oval or oblong, 5 to $12 \mathrm{~cm}$. long, 2.5 to $5 \mathrm{~cm}$. broad, coriaceous, glabrous on both sides, the apex shortly acuminate, cuneate at the base; flowers in axillary racemes, pale violet to rose-colored, in clusters of 2 on a short branchlet, with a space between; racemes about $20 \mathrm{~cm}$. long; pedicels $3 \mathrm{~mm}$. long; calyx $6 \mathrm{~mm}$. long, brown-tomentose; standard $1.4 \mathrm{~mm}$. long, orbicular, the outside silky; pod usually 2 or 3 -seeded, 5 to 10 $\mathrm{cm}$. long, at the seeds about $2 \mathrm{~cm}$. wide, constricted between the seeds, compressed, almost woody, slightly brown-tomentose or glabrous.

Near Guayanilla, close to the bank of the river at Los Indios; near Guanica, by the river at Barinas; near Cabo Rojo, around Hacienda Garcia; near Mayaguez.Jamaica (Bentham), Haiti, Guadeloupe, Martinique.

\section{Lonchocarpus glaucifolius Urh.}

(Urban, 297.)

Shrub with climbing branches or tree 5 to 8 meters high; leaves 5 or 7 -foliolate; leaflets elliptical or elliptical-oblong, rounded at the apex or shortly and obtusely acuminate, obtuse or rounded at the base, 4 to $13 \mathrm{~mm}$. long, 2 to $7 \mathrm{~cm}$. wide, glabrous, veins on the upper surface impressed; inflorescence 6 to 14 -flowered, in lax racemes; calyx 4 $\mathrm{mm}$. deep; flowers rose-colored; standard orbicular, 12 to $15 \mathrm{~mm}$. long; wings $4 \mathrm{~mm}$. wide; pod linear or broadly linear, 6 to $14 \mathrm{~cm}$. long, 1 to $1.5 \mathrm{~cm}$. wide, 2 to 7 -seeded, coriaceous; seeds oval-reniform, $9 \mathrm{~mm}$. long, $5 \mathrm{~mm}$. wide, dark brown.

In the primeval mountain forests near Rincon at Calvache; near Aguada on Mount Piedra Blanca and in the mountain forests at Rio Grande; near Aguadilla, in the mointains at Espinal; near Quebrarlillas at Caño Grande. Indigenous.

Local name, geno. 


\section{Lonchocarpus latifolius (Willd.) H. B. K.}

(Urban, 297.)

Tree 6 to 20 meters high; leaflets 5 to 9 , oval-oblong, acuminate, paler and minutely puberulous beneath, or glabrescent, 5 to $15 \mathrm{~cm}$. long, 2.5 to $5 \mathrm{~cm}$. wide, subcoriaceous; inflorescence densely racemose, 7.5 to $12 \mathrm{~cm}$. long, many-flowered; calyx $2.2 \mathrm{~mm}$. deep; flowers purple, 8.5 to $11 \mathrm{~mm}$. deep; standard thinly silky; pod oblong or broadly linear, 5 to $7.5 \mathrm{~cm}$. long, 1.7 to $2.1 \mathrm{~cm}$. broad, 1 or 2 -seeded, not at all, or somewhat constricted between the seeds, flat, thin, glabrescent.

Near Bayamon, in woods at Palo Seco; Sierra de Luquillo in the woods on Mount Jimenez; near Quebradillas on the bank of the river; near Manati in thickets on the coast, and at Abra de los Muertos. - Cuba (Wright), Jamaica, Haiti, St. Kitts, Guadeloupe, Dominica, Martinique (Sieber), St. Lucia, St. Vincent, Trinidad. Common also in the adjoining parts of South America. Central America to Nicaragua. The hard wood is used in making furniture (Cook and Collins, p. 178.)

Local names, palo hediondo, forte ventura.

\section{PISCIDIA L.}

\section{Piscidia L. Syst. ed. 10. 2: 1155. 1759.}

Calyx subcampanulate, with the teeth short and wide, the two upper ones slightly adhering; standard orbicular; wings oblong-falcate, adhering to the obtuse keel; petals of the keel cohering along the back; upper stamen free at the base, united with the others at the middle in a closed tube; ovary sessile with numerous seeds; style reflexed, filiform, the stigma small, terminal; pod linear, flat, each suture widening into 2-veined wings; seeds ovate, compressed.-Tree with imparipinnate leaves; leaflets opposite; flowers white and blood-red, in short panicles; bracts opposite on the pedicel, subelliptic, subcoriaceous, caducous.

\section{Piscidia piscipula (L.) Sarg.}

(Urban, 297.$)$

Tree 20 meters high; leaflets 3 to 5 -jugate, pubesceut or glabrescent, oblong or elliptical, pointed or blunt; flowers. 1.2 to $1.6 \mathrm{~cm}$. long; wings each $1.2 \mathrm{to} 1.6 \mathrm{~cm}$. broad, transversely striate, lacerate or repand; legume 5 to $10 \mathrm{~cm}$. long, $8 \mathrm{~mm}$. broad, puberulous; seeds 6 to 8 , transversely oblong, black, $7 \mathrm{~mm}$. long.

In thickets and forests on the coast near Fajardo and near Salinas de Cabo Rojo.South Florida (Chapman), Florida Keys (Sargent), Bahama (Grisebach), Jamaica, Haiti, St. Thomas, St. Croix, St. John (Eggers), St. Martin (Stockholm Herbarium), St. Bartholomew (do.), Antigua (Grisebach), Guadeloupe, St. Lucia (Grisebach), St. Vincent, Barbatos, Grenada, South Mexico. Southern parts of North America.

Local name, ventura.

\section{ANDIRA lam.}

Tonacapoua А ивL. Hist. Pl. Gui. 2: Suppl. 9. pl. 37\%. 1775. Andira Las. Eneye. 1: 171. 1783.

Calyx broadly campanulate or subturbinate, truncate, with short indistinct teeth; petals clawed; standard suborbicular; wings and potals of the keel nearly straight, oblong, obtuse, the latter imbricate but not comnate on the back; upper stamen free, or rarely connate with the rest; ovary stipitate or rarely sessile, 2 to 4 - (rarely 1-) ovulate; style short, incurved; stigma small, terminal; pod drupaceous, ovoid or obovoid, often some- 
what compressed, with a more or less fleshy mesocarp and a thick subligneous endorarp; seeds 1, pendulous. - Strong trees; leaves imparipinnate; leaflets opposite, rarely alternate, often stipellate; flowers rose-colored or violet, fragrant, in terminal pyramidal panicles, subsessile, usually crowded; bracts and bracteoles small, deciduous.

\section{Andira jamaicensis (W. Wright) Urb. ${ }^{a}$}

\section{(Urban, 298.)}

Tree 10 to 20 meters high with firm woody branches, the young twigs slightly graypubescent; petioles 5 to $7.5 \mathrm{~cm}$. long; leaflets 9 to 13 , the pairs more than $2.5 \mathrm{~cm}$. apart, oblong or lanceolate, or the terminal one obovate, 5 to $7.5 \mathrm{~cm}$. long, 1.5 to $2.5 \mathrm{~cm}$. wide, acuminate or subacute, the base scarcely rounded, subsessile, subcoriaceous, both sides glabrous, dark green, shining; flowers in pyramidal panicles, 15 to $30 \mathrm{~cm}$. long, with distant, spreading, stalked, racemose, closely flowered branches; calyx subsessile, silky, about $4.5 \mathrm{~mm}$. deep, brownish red; corolla reddish, violet, or pale purple, 13 to $15 \mathrm{~mm}$. deep, the standard 6.5 to $8.5 \mathrm{~mm}$. broad; ovary stalked, glabrous or shightly ciliate, 3 or 4-ovulate; legume green, subrotundate, about $2.5 \mathrm{~cm}$. in diameter, obtusely carinate; or shortly ovate, or obovate, 3.5 to $4 \mathrm{~cm}$. long, slightly or not at all carinate.

Near Bayamon in woods; Sierra de Luquillo, in woods between Mavi and Mount Jimenez; in the calcareous mountains near Juncos; near Coamo in woods at Pedro Garcia and at Los Baños; between Coamo and Aguas Buenas on the roadside; near Yauco; near Guanica on Mount Puerco and at Barinas; near Nayaguez; near Naricao, in the forests of Mount Montoso; near Utuado in the rocky mountains at Los Angcles.-Cuba, Jamaica, Haiti, and in related forms (variety sapindoides (Benth., Griseb.), with larger flowers and longer pedicels, St. Thomas, St. ('roix, St. John (Eggers), St. Kitts (Grisebach), Antigua, Guadeloupe, Dominica, Martinique, St. Lucia, St. Vincent, Tobago, Trinidad (Sieber). Tropical America and west tropical Africa; very abundant in Central America, Guiana, Venezuela, north Brazil, and eastern Peru.

The Brazilian and west African specimens are generally rather longer-flowered and stiffer-leaved than those from Gruiana, the West Indies, and Central America; but no tangible characters nor constant size in the flowers can be found to separate them even into marked varieties.

Local names, moca, moca blanca.

\section{ABRUS L.}

Abrus Anaxs. Fam. 2: 327. 1763.

Hoepfneria Vatke, Oester. Bot. Zeitsch. 29: 222. 1879

Caly $\mathrm{x}$ campanulate, truncate or shortly and broadly toothed; standard ovate, the short claw adhering to the base of the staminal tube: keel much curved, the petals united from the base, often longer than the wings; stamens 9 united in a sheath open on the upper side, the upper one deficient; ovary sessile, with indefinite ovules; style short, incurved; stigma terminal; pod oblong or linear, flat, 2-valved, with cellular partitions between the seeds. Shrubs or undershrubs; stems ustally twining or trailing, woody at the base; leaves paripinnate, the leaflets many-jugate, the common petiole ending in a short point; flowers small, rose-colored or white, in clusters on lateral thickened nodes or in axillary or terminal racemes; bracts small, often persistent; bracteoles 2 on the calyx.

\section{Abrus precatorius L.}

(Urban, 298.)

Shrub with slender woody wide-climbing glabrous or slightly pubescent branches; leaves abruptly pinnate, 4 to $8 \mathrm{~cm}$. long; leaflets 10 to 15 -jugate, oblong or obovate, 
1 to $2 \mathrm{~cm}$. long, blunt, subsessile, glabrous or the lower side slightly silky; racemes axillary or terminal, dense, stalked. 5 to $7.5 \mathrm{~cm}$. long, the flowering part $2.5 \mathrm{~cm}$. long; calyx truncate, thinly silky, the teeth very short; corolla $9 \mathrm{~mm}$. long, reddish, rarely white or purple; pod sessile, 2.5 to $3.5 \mathrm{~cm}$. long, $1.2 \mathrm{~cm}$. broad, oblong, rostrate, subcoriaceous, flat, 2-valved, with cellular partitions between the seeds, glabrous when mature; seeds 4 or 5 , globose, shining, scarlet, with a black spot at the base.

Near Bayamon in sandy soil; near Salinas de Cabo Rojo; near Mayaguez, on hedges at Guanajibo.-Bahama, (uba, Jamaica, Haiti, St. Thomas (Eggers), St. Croix, St. John (Eggers), St. Bartholomew (Euphrasén), Intigua (Grisebach), Guadeloupe, Dominica, Martinique, St. Vincent, Barbados (Maycock), Tohago, Trinidad. Widely distributed through the Tropics, but often planted.

The brilliant red seeds with a black spot at the hilum are strung by the women of Hindustan and are used instead of beads for ornaments for the neck and also for rosaries, hence the name "pater noster herb." The seeds are extremely poisonous when taken in large quantities, and in India they have played an important rôle in many a crime.

Local names, peronia, peronilas.

\section{CLITORIA L}

Clitoria L. Sp. Pl. 2: 753. 1753.

Calyx tubular, the 2 upper lobes slightly comnate, the lowest narrow; standard large, erect, open, narrowed at the base without auricles; wings shorter, spreading, adhering to the keel in the middle; keel shorter, incurved, acute; upper stamens free or more or less united with the others; anthers uniform; ovary stipitate, with several ovules; style elongated, incurved, more or less dilated upward and bearded longitudinally on the inner side; pod linear, flattened, the upper or both sutures thickened, the sides flat or convex, occasionally bearing a raised longitudinal rib, dehiscent; seeds globose or flattened.- Ilerbs or shrubs, short and erect or with long twining branches; leaves pinnate, with 3 or several leaflets or occasionally only 1; stipules persistent, striate; flowers often large, purple, blue, white, or red, often two-colored, solitary or clustered in the axils or in pairs crowded in short racemes; bracts stipule-like, persistent, the lower ones in pairs, the upper united into one.

This genus is readily distinguished by its large tubular calyx.

KEY TO THE SPECIES.

Leaflets 2 or 3 -jugate (rarely 4 or 5 ), ovate, blunt or oval; perluncle short, 1-flowered; bracteoles sulorbicular, about one-fourth as large as the calyx; calyx lobes lancenlate, acuminate; legume linear, pubescent. (Section Ternatea Benth.)

Leaflets only 3. (Section Neurocarpu a Benth.)

Stem twining; leaflets acute.

Rhizome woody; stem erect. nearly simple, ascending; leaflets obtuse, retuse, or emarginate.

1. C. ternatea.

2. C. rubiginosa.

3. C. laurifolia.

\section{Clitoria ternatea L.}

(Trhan, 299.)

Herbaceous, suffrutescent; stem twining; leaflets 2 to $3 \mathrm{~cm}$. long, about $1.5 \mathrm{~cm}$. wide; peduncle 2 to $4 \mathrm{~mm}$. long: flowers large, resupinate, blue and white; calyx 1.5 $\mathrm{cm}$. deep; standard $5 \mathrm{~cm}$. long; pod 6 to $13 \mathrm{~cm}$. long, $1 \mathrm{~cm}$. wide.

Cultivated and seemingly wild near Bayamon; near Fajardo in Bromelia copse toward the sea; near Mayaguez, toward Guanajibo.--Bahama, Cuba, Jamaica, Haiti, St. Thomas, St. Croix, St. John (Eggers), St. Bartholomew (Stockholm Herbarium), 
St. Kitts, Antigua (Grisebach), Guadeloupe, Dominica, Martinique, St. Vincent, Barbados (Giisebach), Grenada, Tobago, Margarita. Native country probably east Africa (Bentham).

Local names, bejuco de conchitas, papito.

Two of the Clitoria species found in Porto Rico are climbing plants, C. ternatea and C. rubiginosa. The former, however, has imparipinnate leaves, 2 or 3 -jugate leaflets, blue and white resupinate flowers, and large bracteoles, while the latter has trifoliolate leaves, and a pod with a prominulous midrib, a peculiarity that rarely occurs.

The third Clitoria species, C. laurifolia, is an erect shrub, with a racemose inflorescence, while the peduncle of C.ternatea and C.rubiginosa has 1 , or at most 3 , flowers. The roots, leaves, and seeds have emetic properties and are used in popular medicines, while the flowers are often employed to color viands and beverages blue.

C. ternatea is widely distributed in the Tropics, and is cultivated in the glass houses of colder countries on account of its showy flowers.

\section{Clitoria rubiginosa Juss.}

(Urban, 299.)

Stem twining; leaflets ovate-oblong, acute, villous or sericeous below, 3 to $10 \mathrm{~cm}$. long, 1.5 to $3 \mathrm{~cm}$. broad; peduncle 3 or fewer-flowered, 4 to $13 \mathrm{~cm}$. long; flower large, purple-variegated; bracteoles ovate-oblong, 3 or 4 times exceeded by the calyx tube; calyx 2 to $5 \mathrm{~cm}$. long; calyx lobes lanceolate, acuminate, almost one-half the length of the tube; standard $5.5 \mathrm{~cm}$. long; legume 3.5 to $5 \mathrm{~cm}$. long, $1 \mathrm{~cm}$. wide, convex, each valve usually with a prominent midrib, glabrescent; seeds globose.

Near Bayamon on hedges; between Aguas Buenas and Caguas along roads; near Cayey, at Campito; near Salinas de Cabo Rojo on the edge of the forests; near Mayaguez, on the sides of Mount Mesa; near Aguada, in the forests at Piedra Blanca.-Cuba (Grisebach), Jamaica (do.), Haiti, Guadeloupe, Martinique, St. Vincent, Tobago, Trinidad (Grisebach). Widely distributed in tropical America.

Local name, flor de pito.

\section{Clitoria laurifolia Poir.}

(Urban, 300.)

Stem erect, herbaceous, pubescent, 30 to $60 \mathrm{~cm}$. high; leaflets 3 , oblong, rarely more than $7.5 \mathrm{~cm}$. long; apex very obtuse, retuse, or emarginate, pubescent beneath; peduncle 1 or 2 -flowered; bracteoles ovate, much exceeded by the calyx; flowers white; calyx about 2.4 to $2.8 \mathrm{~cm}$. long, silky-pubescent, rarely glabrous; teeth ovate-lanceolate, acute or acuminate, 0.8 to $1 \mathrm{~cm}$ long, the upper more or less connate, the lowest longer and acuminate; corolla about $5 \mathrm{~cm}$. long; legume 2.5 to $6.25 \mathrm{~cm}$. long, stipitate, with a prominent midrib, rarely destitute of it; seeds ovoid-globose.

Near Bayamon in sandy soil, near Dorado in plains near the coast.-Cuba, Haiti (Bentham), Trinidad. Tropical South America.

\section{CENTROSEMA Benth.}

\section{Bradburya RaF. Fl. Ludov. 104. 1817.}

Centrosema Bentu. Ann. Wien. Mus. 2: 117. 1838.

Calyx shortly campanulate, the segments subequal, the two upper sometimes connate; standard broadly orbicular, spurred on the back over the short, arehed, complicate claw, rarely with a more or less distinct gibber (tubercle); wings arcuate, obovate; keel hardly shorter than the wings, wide, inflexed; upper stamen free or more or less connate with the others; ovary subsessile, multiovulate; style inflexed, more or less dilated at the apex; stigma terminal, slightly bearded; pod subsessile, linear, 
compressed, with incrassate sutures, 2-valved, valves with a prominent nerve on both sides near the margin, or winged near the lower suture; seeds obliquely oblong.-Twining or prostrate herbs or undershrubs; leaves pinnate; leaflets 3 , rarely 1,5 , or 7 , sometimes so close together that they appear digitate; stipules persistent, striate; flowers showy, often large, whitish, rose-colored, violet, or bluish, on axillary peduncles, 1 to numerous; lower bracts of the same form as the stipules, in pairs or connate above, bearing 1 or 2 flowers in the axils; bracteoles appressed to the calyx, striate, larger than the bracts.

The genus Centrosema strongly resembles Clitoria in habit, but can be distinguished from it by the spurred standard and the much shorter calyx.

\section{KEY TO THE SPECIES.}

Upper ralyx segments much shorter than the tube.

Leaves 16 to $27.5 \mathrm{~cm}$. long, turning black in drying; terminal leaflet 8.5 to $12 \mathrm{~cm}$. long, broadly ovate; bracteoles ovate, twice as long as the calyx; calyx teeth very short, unequal; pod $15 \mathrm{~cm}$. long, 11 to $13 \mathrm{~mm}$. wide; ribs of the legume valves prominulous, $3.3 \mathrm{~mm}$. distant from the margin; corolla white, variegated with bright purple and yellow.

1. C. plumieri.

Upper caly x segments longer, rarely a little shorter, than the tube.

The upper calyx segments equal to the tube, connected below the summit, inferior calyx lobe longer than the tube; leaflets 5 to $7.5 \mathrm{~cm}$. long, 2.5 to $3.7 \mathrm{~cm}$. wide, ovate; bracteoles - ovate, as long as the calyx; pod 5 to $6.5 \mathrm{~mm}$. wide, the ribs of the legume valves $2.2 \mathrm{~mm}$. from the margin.

2. C. pubescens.

The upper calyx segments longer than the tube, free or connate at the base; leaflets 3.5 to $5 \mathrm{~cm}$. long, 1.8 to $2.5 \mathrm{~cm}$. wide; bracteoles ovate, somewhat exceeded by the calyx; pod $4.4 \mathrm{~mm}$. wide; ribs of the legume valves juxtamarginal.

3. C. virginianum.

\section{Centrosema plumieri (Turp.) Benth. $a$}

(Trban, 300.)

Stem twining, suffrutescent at the base; peduncle 2 or 3 - (rarely 5 or 6 -) flowered; ralyx $6.5 \mathrm{~mm}$. long; standard spurred above the calyx, $4 \mathrm{~cm}$. in diameter, orbicular; wings narrowly oblong, falcate, shorter than the standard; keel large, broader and shorter than the wings; legume $15 \mathrm{~cm}$. long, $1.3 \mathrm{~cm}$. wide, erect or slightly curved.

Near Bayamon in thickets.-Cuba, Jamaica. Haiti, St. Thomas, St. Kitts (Grisebach), Antigua, Martinique, St. Vincent, Grenada, Trinidad (Grisebach). Indigenous in tropical America.

Centrosema plumeri is common on fences in the West Indies. The leaflets and flowers are larger than those of the other two speries of Centrosema found in Porto Rico. The roots contain a volatile oil and a resin that is much used in popular medicine.

Loral name, conchita de Plumier (Cook and Collins).

\section{Centrosema pubescens Benth. $b$}

\section{(Urban, 300.)}

Stem twining; flowers few, at the apex of the peduncle, yellow; calyx 6.5 to $11 \mathrm{~mm}$. deep; standard $2.5 \mathrm{~cm}$. in diameter; keel wide, incurved; pod 15 to $20 \mathrm{~cm}$. long, 3 to $6.5 \mathrm{~mm}$. wide. 
Near Bayamon in thickets; near Coamo, in the valley of El Fuerte River; near Pepino; on declivities at Eneas; near Maricao in thickets on the river bank; near Cabo Rojo in copses; near Mayaguez; near Añasco, in thickets at (alvache; near Rincon in coast districts; near Aguadilla, at Barrio Victoria.- ('uba, Jamaica, Haiti, Antigua (Grisebach), Guadeloupe, Martininque, St. Vincent, Trinidad. Widely distributed in tropical America.

Local name, flor de pito.

\section{Centrosema virginianum (I.) Benth. $a$}

(Urban, 300.)

Stems slender, firm, herbaceous, widely climbing; peduncle axillary, 1, sometimes 4-flowered; calyx 9 to $12 \mathrm{~mm}$. deep; standard $2.5 \mathrm{~cm}$. in diameter; flowers blue or white becoming blue; pod 7.5 to $10 \mathrm{~cm}$. long, 3.3 to $4.4 \mathrm{~mm}$. broad, nearly straight.

Near Bayamon in thickets and grassy places, near Yabucoa, on the declivities of Mount Canto de Gallo; near Cayey, at Morillos Brook; near Guanica, in meadows at Montalba and between La Boca and Barinas; near Salinas de Cabo Rojo on the edge of the woods; near Mayaguez, on the declivities of Mount Mesa; near Utuado, in thickets at Cayuco.-Bermuda (Hemsley), Bahama, Cuba, Jamaica, Haiti, St. Thomas, St. Croix, St. John (Eggers), St. Martin (Stockholm Herbarium), St. Bartholomew (do.), St. Kitts, Antigua (Grisebach), Guadeloupe, Dominica (Grisebach), Martinique, St. Vincent, Bequia (Kew Bull. No. 81, p. 246), Mustique, Canouan (do.), St. Lucia (Grisebach), Barbados, Grenada, Tobago, Margarita. A common tropical American species, extending north to Maryland. Also in western tropical Africa.

Centrosema virginianum resembles C. pubescens closely, but has a much narrower pod.

Local name, conchita virginia (Cook and Collins).

\section{3a. Centrosema virginianum angustifolium (DC.) Griseb.}

(Urban, 301.)

Leaflets linear, or the inferior oblong.

Near Mayaguez, on Mount Mesa.-Bahama, Cuba, Jamaica, Haiti, St. Martin (figure in Stockholm Herbarium), Antigua (Grisebach), Martinique.

54. TERAMNUS P. Br.

Teramnus P. Br. Hist. Jan. 290. 1756.

Calyx campanulate, the two upper teeth connate or separate, the others subequal; standard obovate, narrowed at the base, exappendiculate; wings narrow, adhering to the keel; keel shorter than the wings, almost straight, obtuse; stamens all connate, the 5 alternate anthers small, abortive; ovary sessile, multiovulate; style short, thick, beardless; stigma capitate; pod linear, 2 -valved, septate between the seeds, rostrate.Slender twining herbs; leaves pinnate; leaflets 3 ; stipules small; flowers minute, in racemes or fascicles in the axils or in pairs or fascicles along the rachis; bracts small; bracteoles linear or lanceolate, striate.

\section{Teramnus uncinatus (L.) Sw.}

(Urhan, 301.)

Twining suffrutescent slender herbs; leaves pinnately 3 -foliolate; petioles 4 to $6 \mathrm{~cm}$. long; leaflets oblong-lanceolate, 5.5 to $8 \mathrm{~cm}$. long, 2.25 to $3 \mathrm{~cm}$. widle, pubescent above, sericeous beneath; flowers in long racemes, small, white or rose-colored, later pale 
blue; calyx 5-parted, lobes equal; standard obovate, $6.6 \mathrm{~mm}$. long, wings narrowly oblong; keel shorter than the lobes of the calyx; pod 3.5 to $5 \mathrm{~cm}$. long, $3.5 \mathrm{~nm}$. wide, slightly falcate, rusty-hirsute, terminated by a recurved beak; seeds yellow, oblong.

Near Bayamon in grassy tracts; near Aibonito at Algarrobo; on precipices between Aibonito and Coamo; near Barranquitas; in thickets on the Isabon River; near Utuado in thickets at Los Angeles; near Pepino, on shady declivities at Eneas; near Maricao in thickets on the river bank; near Mayaguez among shrubs in moist meadows; near Cabo Rojo in thickets.-Cuba, Jamaica, Haiti. Tropical America.

In the Antilles the leaves of $T$. uncinatus are used as a purgative and the flour of the seeds for poultices to reduce inflammation.

Local name, cresta de gallo blanco.

\section{ERYTHRINA L.}

Erythrina L. Sp. Pl. 2: 706. 1753.

Mouricou Adans. Fam. 2: 326. 1763.

Calyx bilabiate or spathaceous, slit down to the base on the lower side, the teeth short or elongated; standard ample and elongated, erect or patent, subsessile or furnished with a claw, not appendiculate at the base, wings short or none; keel much shorter than the standard, shorter or longer than the wings, its petals often free; upper stamen free or connate with the others below; anthers uniform; ovary stalked, multiovulate; style subulate, incurved, beardless, with a small, terminal, subcapitate stigma; pod stalked, linear, falcate, narrowed at the base and apex, compressed or subterete, much constricted between the seeds, both sutures or only the upper one splitting; seeds distant, ovoid or oblong.--Trees, or at times almost herbaceous shrubs, with thick, often aculeate branches; leaves pinnate with 3 leaflets; stipules glandular, at the base of each leaflet; flowers large, usually scarlet, axillary or terminal, in racemes or in small clusters in the axils; bracts and bracteoles small or wanting.

KEY TO THE SPECIES.

Calyx broadly campanulate; keel gamopetalous; standard longstipitate.

1. E. glauca.

Calyx subtubulose, truncate; standard sessile or subsessile, oblong.

Keel petals free; keel short, a little shorter than the calyx; leaves chartaceous; seeds scarlet with a black spot.

2. E. corallodendron.

Keel gamopetalous, long, only a little shorter than the standard; leaves membranous or subpapyraceous; seeds dark brown.

\section{Erythrina glauca Willd.}

3. E. micropteryx.

\section{(Urban, 302.)}

Tree 13 meters high; leaves 20 to $30 \mathrm{~cm}$. long; leaflets broadly ovate, obtuse at the apex, rotundate at the hase, 9 to $12 \mathrm{~cm}$. long, 8 to $8.5 \mathrm{~cm}$. wide, coriaceous or chartaceous; racemes 15 to $20 \mathrm{~cm}$. long; calyx 1 to $2 \mathrm{~cm}$. cleep; flowers deep saffron yellow; standard 5 to $6.5 \mathrm{~cm}$. long; wings $2.5 \mathrm{~cm}$. long; keel 3 to $3.5 \mathrm{~cm}$. long; pod sublignose, 17 to $25 \mathrm{~cm}$. long, $1.5 \mathrm{~cm}$. wide; seeds dark brown.

Near Bayamon, on the bank of the river around Guinabo.-Cuba (Grisebach), Guadeloupe, Martinique, St. Vincent, Venezuela. Tropical America.

The saffron-yellow flowers and the very long (sometimes $25 \mathrm{~cm}$.) woody pods of $E$. glauca are very striking. It has by far the deepest calyx of all the Porto Rican species.

Local name, bucago. 


\section{Erythrina corallodendron L.}

(Urban, 302.)

Shrub 3 to 4 meters high, climbing, or tree 3 to 6 meters high, armed; leaflets broadly ovate-rhomboid, 1 to $1.5 \mathrm{~cm}$. wide, 5 to $14.5 \mathrm{~cm}$. long; flowers in axillary racemes 12 to $35 \mathrm{~cm}$. long, coral-colored; standard 5 to $6.5 \mathrm{~cm}$. long; calyx 8.5 to $10 \mathrm{~mm}$. long. a little exceeded by the wings; pod $10 \mathrm{~cm}$. long, $1 \mathrm{~cm}$. wide.

Near Bayamon, in calcareous mountains; near Sabana Grande, in thickets on the rocky banks of Estero River near the cataract; near Añasco; near Rincon, in thickets on the shore at Cabo San Francisco.-Bermuda (introduced, Hemsley), Cuba, Jamaica (in the form grandiflora), Cayman (Hitchcock), St. Thomas (Eggers), St. (roix (do.), St. John, St. Bartholomew (Wikström), St. Kitts (Euphrasén), Antigua (Grisebach), Guadeloupe, Martinique, St. Vincent, Grenada, Tobago (in the form grandiflora), Mexico. Tropical America.

Erythrina corallodendron on account of the size of its flowers is a very noticeable tree. It differs from E. microptery $x$ in having a short keel and red seeds. The three Erythrina species of Porto Rico are at first armed, later they become glabrous.

From the soft, corky wood of $E$. corallodendron, coral wood, arbol madre of the Mexicans, are manufactured corks, light ladders, etc.

Local name, bucare.

\section{Erythrina micropteryx Poepp.}

(Urban, 301.)

Tree 15 to 20 meters high, armed; leaflets 11 to $16 \mathrm{~cm}$. long, 7 to $12 \mathrm{~cm}$. wide, orbicularoval, obtuse or abruptly acuminate; flowers in racemes, bright red; calyx $6 \mathrm{~mm}$. deep; standard elliptical or narrowly oval, 3.5 to $4.2 \mathrm{~cm}$. long; wings twice as long as the calyx, obovate or oval-elliptical; keel a little shorter than the standard, bidentate; pod 7 to $13 \mathrm{~cm}$. long, chartaceous; seeds dark brown.

Cultivated for shading coffee plantations and seemingly wild near Bayamon; near Cayey, at Quebrada Arriba; near Adjuntas, on Mount Capaes; near Utuado, at Salto Arriba; near Lares, at Mirasol and at Espino; near Quebradillas and near Toa Alta.Cuba, Jamaica, Guadeloupe, Martinique, Trinidad. Indigenous in Peru.

The long keel of $E$. micropteryx makes it easy to distinguish from the other Porto Rican species; the brown seeds, from E. corallodendron.

Local names, bucare, palo de boyo; Cuba, peñon de Cuba (Eggers); Guadeloupe, immortel jaune (Duss); Martinique, erythrine de cayenne (Hahn); Peru, a'ma-sísa (Spruce).

\section{RUDOLPHIA Willd.}

Rudolphia Wiblo. Ges. Naturf. Fr. Berlin Neue Schrift 3: 451. 1801.

Calyx tubuliform, the 2 upper segments connate or subconnate, the 2 lateral much smaller, the lowest one cuspidate and slightly arcuate; standard oblong, plicate; the wings and the free petals of the keel narrow and much shorter than the standard; upper stamen free; ovary stipitate or sessile; style more or less dilated in the middle; stigma terminal, subcapitate; pod elongated, flat, tipped with the persistent base of the style, 2-valved; valves finally tortuose, pulpy within; seeds flat, obovate.-Twining undershrubs or herbs; leaves with one leaflet; flowers elongated, purple, red, or flesh-colored, in axillary racemes or fasciculate on the rachis; bracts and bracteoles small and caducous. 


\section{Rudolphia volubilis Willd.}

(Urban, 302.)

Twining; leaflets cordate, rarely broadly ovate, 5 to $10 \mathrm{~cm}$. long, 3.5 to $7 \mathrm{~cm}$. wide, truncate at the base, acuminate; pedicels 5 to $7 \mathrm{~mm}$. long; calyx purple, 2.0 to $2.5 \mathrm{~cm}$. long; corolla coral-colored, pale purple or blood-red; standard 4.0 to $4.5 \mathrm{~cm}$. long, 1.2 to $1.3 \mathrm{~cm}$. wide; wings 1.5 to $1.8 \mathrm{~cm}$. long, 0.7 to $1 \mathrm{~mm}$. wide; keel petals 1.2 to 1.6 cm. long, 0.7 to $1 \mathrm{~mm}$. wide.

In the primeval forest, not unusual-e. g., near Bayamon; near Rio Blanco; in Sierra de Luquillo on Mount Jimenez; Sierra de Naguabo on Mount Piedra Pelada; near Yabucoa, at Guayabota and on Mount Piedra Azul; near Hato Grande on Mount Gregorio; near Aibonito, at Guyon; near Cayey, on Mount Torito; near Adjuntas on Mount Serrote; near Peñuelas, at Las Cruces; near Maricao on Mount Alegrillo; near Mayaguez on Mount Mesa; in Sierra de Lares at Guajataca. Indigenous.

Local names, bejuco colorado, bejuco de alambre, bejuco prieto

\section{MUCUNA Adans.}

\section{Mucuna Adans. Fam. 2: 325. 1763.}

Calyx broadly campanulate, very unequally toothed, the upper tooth (consisting of 2 combined) broarler, the lowest longer; standard folded together, shorter than the wings, with inflexed auricles at the base; wings oblong or ovate, incurved, often adhering to the keel; keel equaling or longer than the wings, incurved at the apex, acute or rostrate; upper stamen free, the rest connate; anthers alternately longer and fixed at the base and shorter and versatile, often bearded; ovary sessile, pauciovulate; style filiform; stigma small, terminal; pod thick, linear or ovate-oblong, often clothed with stinging hairs, 2-valved, septate between the seeds, the valves coriaceous, plane or variously costate or lamellate, sometimes winged.- ('limbing herbs or shrubs (one species erect); leaves pinnate; leaflets 3 , with stipels; stipules caducous; flowers usually large, purple, red, or yellowish green, rarely light green, in axillary racemes or fasciculate at the end of the pedunele; bracts usually small, selelom large, usually caducous.

\section{KEY TO THE SPECIES.}

Pod oblong, nearly straight, with close, broad, irregular, coriaceous undulated lamellations and yellow bristly hairs in the hollows, 2 or 3 -seeded; leaflets papyraceous, the upper surface with a few deciduous adpressed bristly hairs, under surface more or less silky, central one ovate-oblong, cuspidate; flowers in capitate heads on firm axillary peduncles; corolla sulphur-yellow. (Section ('itra DC.)

Pod linear, curved, longitudinally ribbed, densely clothed with brown silky bristles, 5 or 6 -seeded; leaflets membranous, the eentral one ovate-rhomboidal broad, bluntish with a mucro, the upper surface glabrous; flowers in short-stalked copious racemes; corolla deep dark purple. (Section StizoLobıu и DC.)

Leaflets ovate or oval-oblong, glabrous; peduncle long, slender, pendulous; pod compressed, flat, without lamellae, often very long, many-seeded, constricted between the seeds; seeds round; hilum linear. (Section CARPopogon.)

1. M. urens.

2. M. pruriens.

3. M. altissima. 


\section{Mucuna urens (L.) D(:}

$$
\text { (Irl)an, 303.) }
$$

Stem woody, slender, wide climbing; leaflets 7.5 to $12.5 \mathrm{~cm}$. long, 7.5 to $8 \mathrm{~cm}$. wide, calyx broadly campanulate, 1.5 to $2 \mathrm{~cm}$. deep; corolla with wings and keel $5 \mathrm{~cm}$. or more long, standard much shorter; pod 10 to $20 \mathrm{~cm}$. long, 3.5 to $4 \mathrm{~cm}$. wide, armed with stinging bristles.

Near Lares in the coffee plantations at Juncal; near Mayaguez; near Aguada, in thickets at Rosario.-Cuba (Richard), Jamaica, (ayman (Fawcett), Haiti, Guadeloupe, Martinique, Tobago. Tropical America, tropical West Africa.

Uucuna urens is readily distinguished from $M$. pruriens by its yellow flowers and its long pod (over $20 \mathrm{~cm}$.) which has close, broad, irregular, coriaceous, undulate lamellations. The seeds are very large and have a broad black band. When polished they are often used for ornaments.

The Mucuna species can be recommended in the Tropics as ornamental plants, but M. urens and M. pruriens must be touched with care on account of the hairs of the pods, which have a most irritating effect upon the skin.

Local names, ojo de buey, matos, matos del monte.

\section{Mucuna pruriens (L.) DC.}

(Urball, 303.)

Stems herbaceous, wide-climbing; leaflets 8 to $14 \mathrm{~cm}$. long, 5 to $7 \mathrm{~cm}$. wide; flowers dark violet; calyx about $1 \mathrm{~cm}$. deep; corolla 3 to $3.5 \mathrm{~cm}$. deep, the standard half as long as the wings; pod 5 to $8 \mathrm{~cm}$. long, 1.5 to $1.75 \mathrm{~cm}$. wide, densely clothed with brown silky bristles.

Near Aguas Buenas on the brook near the town; near Juncos, at Valenziano Arriba climbing on high trees; near Guayama, in mountain woods beyond Guamani; near Coamo, in the valley of El Fuerte River; near Peñuelas, on the bank of the river toward Tallaboa Alta; near Cabo Rojo in thickets; near Mayaguez, at Algarrobo; near Rincon in thickets on the shore. Cuba (Grisebach), Jamaica, (ayman (Hitchcock), Haiti, St. Thomas (Eggers), St. Croix (do.), St. John (do.), Guadeloupe, Martinique, St. Vincent, Grenada, Tobago. Cosmopolitan in the Tropies.

Mucuna pruriens differs marked'y from M. urens in that it has purple flowers and a much smaller, longitudinally ribbed pod.

The root and the seeds have long been valued in East Indian medicine, and in the West Indies and in Europe the hairs were formerly considerably used medicinally. 'The young tender pods are cooked and eaten as a vegetable.

Local name, pica-pica (Urban); cowhage or cowitch (Cook and Collins).

\section{Mucuna altissima (Jacq.) DC.}

\section{(Urban, 304.)}

Twining; leaflets glabrous, ovate or oval-oblong, $7.51012 .5 \mathrm{~cm}$. long, $2.5 \mathrm{to} 6 \mathrm{~cm}$. wide, membranous; petiole slender, 7.5 to $12.5 \mathrm{~cm}$. long; peduncle 30 to $120 \mathrm{~cm}$. long, racemes short; calyx sericeous, 4-toothed; the three superior teeth suall or obsolete, the inferior longer; flowers dark violet or pale flesh-colored; corolla $3.6 \mathrm{~cm}$. long; staudard ovate-oblong, nearly as long as the wings; beak of the keel cartilaginous, bluntish, equaling the wings; legume $15 \mathrm{~cm}$. long, $3.7 \mathrm{~cm}$. broad below its pointed top, with numerous, transverse, convex lines, compressed, spathulate, oblong, hirsute, callous on the margins; seeds orbicular, compressed (1.6 to $2 \mathrm{~cm}$. in dianeter), almost wholly surrounded by the raphe. 
Near Bayamon in forests on the bank of the river; Sierra de Naguabo, near Minas de Cobre at Rio Blanco; near Yabucoa, in the primeval forest on Mount Sombrero at La Pandura; between Adjuntas and Ponce, in shady localities by the river at Coral Viejo.-Cuba, Jamaica (Grisebach), Haiti, St. Kitts, Guadeloupe, Martinique, St. Vincent. Panama, Brazil.

Local names, mato, tortera.

58. CALOPOGONIUM Desv.

Calopogonium Desv. Ann. Sc. Nat. 9: 423. 1826.

Stenolobium Benth. Ann. Wien. Mus. 2: 125. 1838.

Cyanostremma Вемтн.; Ноок. \& ARn. Bot. Beech. 415. 1841.

Calyx campanulate or short tubuliform, the 2 upper teeth free or more or less connate; standard obovate, the base with inflexed auricles; wings narrow, adhering to the keel; keel obtuse, usually shorter than the wings; upper stamen free; ovary sessile, multiovulate; style slender; stigma terminal, capitate; pod linear, compressed or at last convex, 2-valved, septate; seeds orbicular, somewhat flat.-High-climbing herbs or undershrubs; leaves pinnate; leaflets 3 , stipellate; flowers small or moderately large, narrow, blue or violet, subsessile, fascicled, forming an elongated raceme; bracts or bracteoles small, caducous.

\section{Calopogonium orthocarpum Urb.}

(Urban, 304.)

A twining plant with subligneous stem; branches, petioles, and peduncles densely rusty-pilose; stipules oblong-lanceolate or lanceolate, acuminate; terminal leaflet ovate-rhomboid or short-ovate, acute; leaflets 3.5 to $10 \mathrm{~cm}$. long, 3 to $8 \mathrm{~cm}$. wide, both sides with appresser hairs; inflorescence racemose, sometimes elongated, sometimes very short, up to $15 \mathrm{~cm}$. long; calyx 6 to $8 \mathrm{~mm}$. deep, campanulate, the teeth longer than the tube, lanceolate, with subulate setaceous apex; corolla blue; standard obovate, $8 \mathrm{~mm}$. long; stamens 9 ; pod linear, erect or suberect, 2.5 to $3.5 \mathrm{~cm}$. long, $4 \mathrm{~mm}$. wide, densely rusty-pubescent, 5 to 8 -seeded; seeds shortly and subobliquely rectangular, convex, pale brown.

Near Bayamon in the fields at Guinabo; near Caguas; near Yauco in the thicket between the River Duey and Mount Rodadero; near Rincon, about Hacienda Dioplo; near Cabo Rojo, in the plains at Joyuda; near Mayaguez.-Haiti.

Local name, jicama.

59. GALACTIA P. Br.

Galactia P. Br. Hist. Jam. 298. 1756.

Odonia Bertol. Lucubr. Herb. 35. 1822.

Sweetia DC. Prod. 2: 381. 1825.

Calyx campanulate, the segmeuts long-acuminate, the lowest usually elongate, the lateral ones smaller than the upper one and the lower one; standard ovate or orbicular, subappendiculate or on the edges at the base inflexed; wings long and narrow, obovate, adhering to the keel; keel equaling or exceeding the wings; upper stamen free or connate with the others at the middle; anthers uniform; ovary sessile or substipitate, with numerous ovules; style filiform, with small terminal stigma: pod linear, straight or incurved, flat, very rarely convex on both sides, 2-valved, pulpy or thinly septate between the seeds.--Prostrate or climbing herbs or erect shrubs; leaves pinnate; leaflets 3 , rarely 1,5 , or 7 , stipellate; bracts small, setaceous, decidluous; flowers surall or moderately large, rarely large, red, violet or white, in axillary racemes clustered 
along the common peduncle in pairs or in fascicles, the lower ones sometimes solitary, seldon without petals; bracts small, setaceous, bracteoles very small.

Professor Urban in Symbolae Antillanae $a$ has given a key to all the species of ( ialactia found in the West Indies and has settled many difficult points. Of this genus only varieties of two different species are found in Porto Rico.

KEY TO THE SPECIES.

Leaflets 2 to $4 \mathrm{~cm}$. long; petals 12 to $15 \mathrm{~mm}$. long; pod 5 to $5.5 \mathrm{~mm}$. wide. 1. G. dubia. Leaflets 2.5 to $6 \mathrm{~cm}$. long; pod 6 to $9 \mathrm{~mm}$. wide.

2. G. striata.

\section{Galactia dubia DC.}

(Urban, 304.)

A twining plant, woody below, herbaceous above, clothed densely or thinly with short or very short reflexed and appressed hairs; stipules lanceolate or narrowly lanceolate, often subulate-acuminate, 2 to $3 \mathrm{~mm}$. long; petiole 1 to $4 \mathrm{~cm}$. long; leaflets 3 , the terminal one oval, elliptical, or obovate, rounded at the apex, more or less emarginate and shortly apiculate, very obtuse or rotundate at the base, 2 to $4 \mathrm{~cm}$. long, 1.5 to $2 \mathrm{~cm}$. wide, the lateral ones one-third or one-half as long as the terminal one, oval or shortly oval, all chartaceous or chartaceous-coriaceous, glabrous above, shortly and appressedly pilose beneath; inflorescence 1 to $5 \mathrm{~cm}$. long, few-flowered toward the top or at the apex; peduncle 0.5 to $4 \mathrm{~cm}$. long, 0.4 to $0.5 \mathrm{~mm}$. thick; pedicel 3 to 4 $\mathrm{mm}$. long; calyx subglabrous or very laxly and appressedly pilose, 7 to $8 \mathrm{~mm}$. long; corolla rose-colored (ex Duchassaing) or purple (ex Duss); standard obovate or orbicularobovate, 12 to $15 \mathrm{~mm}$. long, 9 to $10 \mathrm{~mm}$. wide, claw 1 to $1.5 \mathrm{~mm}$. long; wings a little shorter or narrower than the keel, 12 to $14 \mathrm{~mm}$. long, $4 \mathrm{~mm}$. wide; upper stamen free; anthers oblong; ovary subsessile, 12 to 14 -ovulate; pod 4 to $5 \mathrm{~cm}$. long, 5 to $5.5 \mathrm{~mm}$. wide, suberect or the upper part more or less incurved, with very short appressed hairs; seeds narrow, ovate-reniform, 3.5 to $5 \mathrm{~mm}$. long, 2 to $3.5 \mathrm{~mm}$. wide, brownishblack, the hilum at or above the middle.

\section{la. Galactia dubia ehrenbergii Urb.}

(Urban, 304.)

Stem, calyx, and pod shortly patent-pubescent; leaflets on the upper surface very shortly pilose, on the lower densely pubescent; terminal leaflets obovate or orbicularobovate, emarginate, the lateral ones shortly oval or subrotundate; calyx teeth often small; standard 11 to $13 \mathrm{~mm}$. long; seeds marmorate, the hilum below the apex; flowers (Sintenis) pale rose-colored or (Stahl) the standard yellow, the wings and keel a bright violet or whitish.

Near Cabeza de San Juan; near Cataño; near Bayamon in the hedges; near Cabo Rojo, in littoral thickets at Joyuda; near Rincon, in the mountains at Barrio Punta.St. Thomas.

\section{1b. Galactia dubia guanicensis Urb.}

(Trban, 304.)

Entire stem woody; calyx and pod appressed-pubescent; flowers white pod 3 to $4 \mathrm{~cm}$. long. The rest as in rhrenbergii.

Near Guanica in thickets on Mount El Maniel. 


\section{Galactia striata (Jacq.) Urb.}

(Urban, 304.)

Perennial twining, stem becoming woody at the base, elongate, clothed with moderately long or short, white, more or less spreading hairs; stipules subulate, 2 to $4 \mathrm{~mm}$. long; peduncle 1.5 to $3.5 \mathrm{~cm}$. long; leaflets 3 , terminal one ovate-elliptical, very obtuse or subrotundate at the apex with a minute mucro, more acutate, obtuse or subobtuse at the base, 3.5 to $6 \mathrm{~cm}$. long, 2 to $3 \mathrm{~cm}$. wide, the lateral ones a little or one-third shorter than the terminal, suboblique, ovate, rounded at the base, rotundate or very obtuse at the apex, all membranous, with short appressed hairs above, pubescent beneath; inflorescence 3 to $15 \mathrm{~cm}$. long, peduncle 0.6 to $1 \mathrm{~mm}$. long, many-flowered above; pedicels 2 to $2.5 \mathrm{~mm}$. long; calyx densely pubescent, its hairs appressed, $7 \mathrm{~mm}$. long, anterior teeth lanceolate, acuminate, $2 \frac{1}{2}$ times as long as the tube, the lateral ones lanceolate, acutate, twice as long as the tube; posterior ovate-lanceolate, obtuse; standard purple, striate, 8 to $9 \mathrm{~mm}$. long, $5 \mathrm{~mm}$. wide, broadly obovate, the claw $1 \mathrm{~mm}$. long; keel almost without color, dorsally arcuate, as long as the standard, wings purple, a little narrower and much shorter than the keel, $8 \mathrm{~mm}$. long, $1.5 \mathrm{~mm}$. wide; upper stamen free, all above incurved; anthers ovate or ovate-oblong; ovary sessile, about 11-ovulate; legume (ex Jacquin) sometimes erect, sometimes a little incurved; seeds reniform, brown, variegated.

\section{2a. Galactia striata tomentosa (Bertol.) Urb.}

(Urban, 305.)

Stem clothed with moderately long, sometimes subequal white hairs, sometimes recurved-pubescent; leaflets ovate, rarely orbicular-ovate or elliptical, rounded at both ends, rarely obtuse, above shortly pilose, beneath densely soft-tomentose; calyx densely patent-pubescent, 7 to $8 \mathrm{~mm}$. long; corolla rose-colored, the outside green or rose-colored or peach-colored; standard 9 to $10 \mathrm{~mm}$. long, 5 to $6 \mathrm{~mm}$. wide, obovate; wings much shorter than the keel, $8 \mathrm{~mm}$. long, 1.5 to $1.8 \mathrm{~mm}$. wide; pod 4 to $7 \mathrm{~cm}$. long, 7 to $9 \mathrm{~mm}$. wide.

At St. Isabel; near Maunabo, in thickets at Punta de la Tuna and at Punta Mala Pasqua; near Aibonito, at Algarrobo; between Aibonito and Coamo along roads and on rocks; near Coamo, at Pedro Garcia and in the valley of the El Tendal River; near Juana Diaz at Escalabrado; near Cabo Rojo, in thickets at Monte Grande and in the woods on the coast.-Haiti, St. Thomas, St. ('roix.

\section{2b. Galactia striata berteriana (DC:) Urb.}

$$
\text { (Urban, 305.) }
$$

Stem clothed with short subretrorse or horizontal hairs; leaflets glabrous or slightly pilose above, clothed beneath with short appressed hairs, narrowed at both ends, the apex obtuse or acutate; flowers red or rose-colored; standard 9 to $10 \mathrm{~mm}$. long; wings a little shorter than the keel, much shorter than the standard, $8 \mathrm{~mm}$. long; seeds 9 to 14 .

Near Bayamon on hedges; near Fajardo in the mountain forests; near Barranquitas in copses near the River Isabon; near (abo Rojo, on Monte Grande; near Rincon, at Barrio del Pueblo and in coast districts; near Aguadilla, at Barrio Victoria.Guadeloupe (?). 
60. DIOCLEA H. B. K.

Dioclea H. B. K. Nov. Gen. \& Sp. 6: 437. pl. 576. 1823.

Hymenospron Spreng. Syst. 4: Cur. Post. 282. 1827.

Crepidotropis WaLP. Linnaea 14: 296. 1840.

Calyx oblique, obconical, with the two upper teeth connate, the lateral ones small, the lowest longer; standard orbicular, reflexed, the base with a pair of inflexed auricles; wings obovate or oblong, free, as long as or rather shorter than the keel; keel incurved, obtuse or rostrate; upper stamen free at the base, connate with the others at the middle; anthers uniform or the 5 alternate ones very small and abortive; ovary subsessile, 2 to many-ovulate; style incurved, dilated or thickened upwards; stigma oblique, truncate; pod oblong, linear, semiorbicular, or somewhat reniform, compressed or somewhat turgid, coriaceous, both sutures narrowly winged or the upper dilated and incrassate, the lower not altered, 2-valved, septate between the seeds; seeds orbicular or somewhat reniform, with a short or long, linear, more or less thickened or somewhat fleshy hilum.-Twining shrubs or undershrubs; leaves pinnate; leaflets 3 , stipellate; stipules small, sometimes spurred, sometimes glandular; flowers blue; violet, or white, in terminal usually elongated racemes, fascicled along the rachis; bracts caducous; bracteoles membranous, persistent.

A moderately small genus, almost entirely tropical American.

\section{Dioclea reflexa Hook. f.}

(Urban, 305.)

Stem woody, climbing to a height of 6 meters, terete, clothed with long, spreading, fine, deciduous yellowish gray hairs; stipules 1 to $1.8 \mathrm{~cm}$. long, scariose, peltate; petioles 5 to $7.5 \mathrm{~cm}$. long; terminal leaflet obovate-oblong, 10 to $15 \mathrm{~cm}$. long, the base rounded, the apex cuspidate, the lateral leaflets similar, subcoriaceous, the upper surface glabrous, lower thinly and deciduously silky; flowers in moderately dense racemes, 10 to $15 \mathrm{~cm}$. long, on firm peduncles often as long; calyx dark brown, $9 \mathrm{~mm}$. deep; corolla dark red or bordering on purple; standard with a yellow spot at the base; pod oval or oval-oblong, 9 to $13 \mathrm{~cm}$. long, 5 to $6 \mathrm{~cm}$. wide; seeds 1 to 3 , oblique, ovate-orbiculate, 2.5 to $3.0 \mathrm{~cm}$. long, 2.2 to $2.6 \mathrm{~cm}$. broad, of a bright or a dark wine color, the older ones becoming brownish.

In primeval forests near Yabucoa, on Mount Guayava, and near Maunabo, at La Pandura; in Sierra de Luquillo between Mavi and Mount Jimenez.-Cuba, Jamaica, Dominica, St. Vincent, Grenada, Tobago. A plant of tropical Asia, Africa, America, and New Guinea.

Local names, mato or bejuco de mato; Cuba, ojo de buey de costa.

\section{CANAVALIA DC.}

Canavali Adans. Fam. 2: 325, 531. 1763.

Canavalia DC. Mem. Legum. 375. 1825.

Calyx bilabiate, the upper lip large, truncate or bifid, the low er one much smaller, entire or trifid; standard reflexed, large, suborbicular or broadly obovate, with or without auricles at the base; wings narrow, falcate or twisted, free; keel incurved, broader than the wings, obtuse or rostrate; upper stamen free below, more or less connate at the center; ovary sessile or very shortly stipitate, multiovulate; style incurved; stigma terminal, small, eapitate; pod oblong, or broadly linear, compressed or subturgid, with a prominent longitudinal wing or rib on each side of the upper suture, 2-valved, slightly septate between the seeds; seeds large, rounder or oblong, compressed. - Large herbs with twining or trailing stems; leaves pinnate; leaflets 3 , stipcllate; stipules small, 
often gland-like or none; flowers usually large, purplish, pink, or white, in axillary racemes; pedicels very short, clustered on lateral nodes along the upper portion of the rachis bracts minute; bracteoles small, orbicular, very deciduous.

\section{KEY TO THE SPECIES,}

Leaflets obovate or orbiculate, very obtuse or retuse, membranous or subpapyraccous; pod oblong, 5 to $13 \mathrm{~cm}$. long, 2 to $3 \mathrm{~cm}$. wide; 'seeds 6 to 8 , chestnut-brown with a black spot, opaque, ovoid, $1.5 \mathrm{~cm}$. long, $1 \mathrm{~cm}$. wide.

Leaflets chartaceous or chartaceous-coriaceous, ovate or narrowly ovate, very shortly and acutely acuminate; pod oblong-linear, 12 to $25 \mathrm{~cm}$. long; seeds ovate-rotundate, 18 to $24 \mathrm{~mm}$. long, 15 to $20 \mathrm{~mm}$. wide, wine-colored, 4 to 6 -seeded.

1. C. obtusifolia.

2. C.rusiosperma

\section{Canavalia obtusifolia (Lam.) DC.}

(Urban, 306.)

Stem biennial, climbing or sometimes prostrate; petiole 5 to $7.5 \mathrm{~cm}$. long; leaflets 7.5 to $10 \mathrm{~cm}$. long, 5 to $6 \mathrm{~cm}$. wide; flowers in 16 down to 12 -flowered racemes on long flexuose peduncles; pedicels stout, 4 to $6 \mathrm{~mm}$. long, springing from fleshy tubercles; calyx broad-campanulate, $1.2 \mathrm{~cm}$. deep, the upper lip rounded, bifid, glabrous; corolla reddish-purple, fragrant; standard 1.8 to $2.5 \mathrm{~cm}$. long; pod with two prominent ribs a little distant from the upper suture.

In coast districts near Yabucoa; in thickets at Puerto de la Vaca; near Patillas, at Guardaraya; near Guanica, at Salinas; near Mayaguez.-South Florida (Chapman), Bermuda (Hemsley), Bahama, Cuba, Jamaica, Cayman, Haiti, St. Thomas, St. Croix, St. John (Eggers), Antigua (Grisebach), Sandy Island, Guadeloupe, Dominica (Grisebach), Martinique, St. Vincent, Bequia (Kew Bull. No. 81, p. 246), Grenada, Tobago, Trinidad (Grisebach). Widely dispersed through the tropies of both hemispheres and often cultivated. C. obtusifolia is a characteristic plant of sandy seashores, where it often creeps among stones. According to Balfour it " is a useful binder of loose sand."

The ovate leaves, the long pod, and the large wine-colored seeds of C. rusiosperma make it easy to distinguish from C.obtusifolia, which has obovate or orbicular leaves, a shorter pod, and chestnut-brown seeds.

Local name, mato de la playa.

\section{Canavalia rusiosperma Urb.}

(Urban, 305.)

Stem twining, reaching $10 \mathrm{~cm}$. in thickness, climbing on high trees; petiole 3.5 to 8 $\mathrm{cm}$. long; leaflets 6.5 to $10 \mathrm{~cm}$. long, 4 to $5.5 \mathrm{~cm}$. wide; inflorescence 5 to $2 b \mathrm{~cm}$. long; calyx $11 \mathrm{~mm}$. long, upper lobes 6 to $7 \mathrm{~mm}$., lower ones 1 to $2 \mathrm{~mm}$. long, thinly pilose or glabrous; petals red (Stahl) or violet (Eggers); standard 2 to $2.3 \mathrm{~cm}$. long; pod 12 to 25 $\mathrm{cm}$. long, 4 to $5 \mathrm{~cm}$. wide with two prominent ribs a little distant from the upper sutures.

In the primeval forests near Maricao, on Mount Montoso; near Lares at Callejones; near Quebradillas.-Haiti, St. Thomas.

Local name, mato colorado.

\section{CAJANUS DC}

Cajan ADANs. Fam. 2: 326, 529. 1763.

Cajanus DC. Cat. Hort. Monsp. 85. 1813.

Cajanum Raf. Sylva Tellur. 25. 1838.

Calyx campanulate, with the two upper teeth connate, the others equal; standard orbicular, reflexed, the base appendiculate with inflexed auricles; wings obliquely obovate; keel with an incurved apex, truncate; upper stamen free, the others connate; anthers uniform; ovary subsessile, multiovulate; style incrassate above the middle, 
beardless, slightly dilated below the obliquely terminal stigma; pod linear, obliquely acute, compressed, 2-valved, with transverse constrictions between the seeds on the outside, scarcely septate within; seeds subglobose, slightly compressed. - Erect undershrubs; leaves pinnate; leaflets 3 ; stipules subulate, caducous; flowers yellow, usually veined with purple, in axillary pedunculate racemes; bracts deciduous.

\section{Cajanus indicus Spreng. ${ }^{a}$}

(Trban, 306.)

Undershrub 2.5 to 3 meters high, erect; branches angular, finely gray-silky with adpressed hairs; petioles 1 to $4 \mathrm{~cm}$. long; leaflets oblong or oblong-lanceolate, 4 to $10 \mathrm{~cm}$. long, acute, subcoriaceous, the upper surface glabrous, the lower gray-silvery; flowers in 2 to 8-flowered axillary racemes, yellow or sometimes the standard spotted with orange; pedicels 0.6 to $1.5 \mathrm{~cm}$. long; calyx silky, 6.5 to $8.5 \mathrm{~mm}$. deep, the teeth lanceolate, not reaching halfway down; corolla 1.5 to $1.8 \mathrm{~cm}$. deep; pod 5 to $8 \mathrm{~cm}$. long, 0.9 to $1.5 \mathrm{~cm}$. broad, 3 to 5 -seeded, finely pubescent.

Cultivated and seemingly spontaneous near Bayamon; near Lares; at Perchas and at Espino; near Maricao on the declivities of Mount Montoso; near Mayaguez, in coast districts at Algarrobo.-Bermuda (Hemsley), Bahama, Cuba (Grisebach), Jamaica, Haiti, St. Thomas, St. Croix, St. John (Eggers), St. Martin (Stockholm Herbarium), St. Bartholomew.(do.), St. Kitts (Grisebach), Antigua (do.), Guadeloupe, Martinique, St. Vincent, Barbados, Grenada, Trinidad (Grisebach), Margarita. Cultivated throughout the Tropies; probably indigenous in Africa.

The seeds taste like a coarse description of field peas and are sold either in the form of split peas or of flour in India, where they are highly esteemed by the natives. The young pods are used for salad. The roots, leaves, and flowers are employed as a medicament. The leaves are considered excellent as a fodder for cattle.

Local names, gandul, gandures.

63. RHYNCHOSIA Lour.

Dolicholus Medic. Vorles. Churpf. Phys. Ges. 2: 354. 1787.

Rhynchosia Lour. Fl. Cochinch. 2: 460. 1790.

Rynchosia MACFAD. F1. Jam. 1: 275. 1837.

Calyx campanulate or tubuliform-campanulate, the 2 upper lobes more or less connate; standard orbicular or obovate, usually with inflexed auricles at the base; wings narrow; keel incurved at the apex; upper stamen free; ovary sessile or nearly so, with 2 or very rarely 1 ovule; style incuved upward, filiform or incrassated; stigma small terminal, capitate; pod oblique, orbicular, oblong, or slightly curved, compressed, 2 -valved, continuous or rarely septate internally; seeds 2 , rarely ovoid or almost reniform, compressed, with a lateral short or oblong hilum, the funicle centrally attachedwith or without a strophiole.-Twining or trailing, rarely erect herbs or undershrubs; leaves pinnate; leaflets 3 , seldom only 1 , without stipels; stipules ovate, subulate persistent or eaducous; flowers yellow, the standard often streaked with brown or purple, more rarely purple, white, or greenish; peduncle axillary, bearing a raceme or rarely single flowers; bracts deciduous

\section{KEY TO THE SPECIES.}

Calyx segments lanceolate, several times longer than the very short tube, and as long as or longer than the standard. (Section Arcyphyllum Ell, as genus.)

Legume pubescent or glabrescent, not constricted, 2.2 to 6.6 $\mathrm{mm}$. long; seeds nearly black, reniform-roundislı, compressed,-about $4 \mathrm{~mm}$. in diameter.

1. R. reticulata.

$a$ Cook and Collins, p. 100, as C'ajanus cajan. 
Calyx-tube obtuse at the base; the calyx segments long or short, always shorter than the standard. (Section Copisma.)

Pod constricted between the seeds, tomentose or glabrescent, 2 to $2.5 \mathrm{~cm}$. long, $8 \mathrm{~mm}$. broad; seeds two-colored, black with a scarlet-yellow ring round the hilum; flowers in many-flowered racemes (10 to $20 \mathrm{~cm}$. long); terminal leaflet 7 to $10 \mathrm{~cm}$. long; leaves beneath and calyx with scattered, very small yellowish glands.

Pod continuous, oblong, tapering at the base, pubescent, soon glabrous, 1.3 to $1.75 \mathrm{~cm}$. long, 4 to $5 \mathrm{~mm}$. wide; seeds black; flowers in lax 6 to 12 -flowered racemes $(5$ to $7.5 \mathrm{~cm}$. long); terminal leaflet 1.8 to $2.5 \mathrm{~cm}$. long; leaves beneath and caly $\mathrm{x}$ with large brownish glands.

2. R. phaseoloides.

\section{Rhynchosia reticulata (Sw.) DC.}

(Urban, 307.)

Stem suffrutescent, twining, from 23 to $90 \mathrm{~cm}$. high, angular, tomentose; leaflets ovate, acute or acuminate, 5 to $7.5 \mathrm{~cm}$. long, 2.25 to $4 \mathrm{~cm}$. widle, 3-nerved and reticulated beneath, with the ribs prominulous, tomentose, or villose on both sides; racemes many-flowered, from 5 to $15 \mathrm{~cm}$. long, axillary; calyx 6.5 to $13 \mathrm{~mm}$. deep, tube very short; corolla yellow or variegated with purple.

Near Bayamon, in littoral thickets; near Cayey, on Morillos brook; near Coamo, in the valley of the El Tendal River; near Maricao, on the edges of the woods; near Guanica, in the thickets of Mount El Maniel; near Cabo Rojo, in copse land; near Mayaguez; near Pepino, on declivities at Eneas.-Cuba, Jamaica, Haiti, St. Thomas, St. Croix, St. John (Eggers), St. Martin (Stockholm Herbarium), St. Bartholomew, St. Kitts, Antigua (Grisebach), Guadeloupe, St. Vincent. Widely distributed in the warmer parts of America.

Rhynchosia reticulata differs from the other two Rhynchosia species found in Porto Rico in having calyx segments that are much longer than the tube, and as long as or longer than the slandard.

\section{Rhynchosia phaseoloides (Sw.) DC. $a$}

(Urban, 307.)

Stem woody at the base, branches herbaceous, a high climbing plant; leaflets ovate or ovate-rhomboid, acuminate, 5 to $9 \mathrm{~cm}$. long, 3.5 to $5 \mathrm{~cm}$. wide, very variable in the down and in the size and form of the leaflets; racemes many-flowered, 8 to $13 \mathrm{~cm}$., sometimes $20 \mathrm{~cm}$. long; flowers yellow with many red-brown lines; calyx $2 \mathrm{~mm}$. long, tomentose; corolla 11 to $15 \mathrm{~mm}$. long; standard striate with purple.

Near Bayamon; near Aibonito, in the primeval forests at Cuyon and at Barrio del Pasto; near Utuado, on shady declivities at Pellejas and in rocky localities of the primeval forest at Los Angeles; near Lares, in mountain forests at Callejones; near Camuy, on the edge of the woods at Cacao; near Manati, on calcareous mountains at Rio Arriba Saliente; near Barceloneta, on the edges of the forests of Mount Florida.-C'uba, Jamaica (variety), Haiti, St. Thomas (Eggers), Guadeloupe (variety), Dominica (Grisebach), Martinique (Copenhagen Herbarium), St. Vincent (variety), Trinidad (Grisebach).Central America, South America.

a Cook and Collins, p. 136, as Inolicholus phaseoloides. 
The differences in the pod and seeds of $R$. phaseoloides and $R$. minima are quite striking. The pod of the former is constricted between the seeds, and the seeds are black with a scarlet-yellow ring around the hilum, while the pod of the latter is not constricted between the seeds, is much smaller, and has seeds that are entirely black. The large brown glands on the under side of the leaves and on the calyx of $R$. minima are most noticeable.

Local names, bejuco de paloma, peronias.

3. Rhynchosia minima (L.) DC.a

(Urhan, 307.)

Stems firm, herbaceous, slender, trailing or twining, minutely tomentose or nearly glabrous; leaflets broadly ovate-rhomboidal, mostly about $2.5 \mathrm{~cm}$. long when full grown, but often much smaller; stipules minute, setaceous; racemes bearing in their upper portion scattered pendulous yellow flowers, rarely exceeding $6.5 \mathrm{~mm}$. in length, on very short pedicels; calyx $4.5 \mathrm{~mm}$. long, subglabrous; teeth linear-setaceous, reaching more than halfway down; corolla $18 \mathrm{~mm}$. deep; standard not silky, yellow veined with purple.

Near Bayamon; near Cataño; near Coamo, in the valley of El Tendal River; near Lares, in thickets at Los Angeles; near Guanica, between Boca and Barinas in ditches; near Cabo Rojo, at Miradero; near Mayaguez, in coast districts at $\mathrm{Algarrobo}$; near Rin('on, at Calvache.-One of the Florida Keys (Chapman), Bahama, Cuba, Jamaica, Cayman, Haiti, St. Thomas, St. Croix, St. John (Eggers), St. Bartholomew (Stockholm Herbarium), Guadeloupe, Martinique, St. Vincent, Bequia (Kew Bull. no. 81, p. 247), Mustique (do.), Union, Barbados, Grenada; Trinidad (Grisebach), Margarita. This species appears to be abundant in almost all subtropical or tropical countries. A com_ mon weed (ex Grisebach).

Local name, frijolillo, pequeño.

64. PHASEOLUS L.

Phaseolus L. Sp. Pl. 2: 723. 1753.

Calyx campanulate or shortly tubuliform, the 2 upper teeth free or connate, the others deltoid or lanceolate; standard orbicular recurved or subtortuous, more or less distinctly auriculate at the base, the edges inflexed toward the base, with or without a longitudinal callus in the middle; wings obovate or rarely oblong, equaling or exceeding the standard, adhering to the keel above the claw, often twisted; keel linear or obovate, with a long obtuse spirally twisted beak; upper stamen free, often incrassated or appendiculate above the base, the rest connate; ovary subsessile, with a cupuliform. discus, multiovulate; style long, incrassated within the beak of the keel and twisted with it, usually longitudinally bearded upward; stigma oblique or on the inner side of the style; pod linear or oblong, terete or compressed, straight or falcate, 2-valved, usually slightly septate between the seeds.-Herbs, either annual or perennial and woody at the base, short and erect or elongated and twining in the same species; leaves pinnate; leaflets 3 or very rarely 1, with stipules; stipules persistent, striate, often calcarate; flowers white, yellow, violet, red, or purple, in axillary racenes; bracts usually deciduous; bracteoles often wide and for some time persistent.

$u$ Cook and Collins, p. 136, as Dolicholus minimus. 
KEY TO THE SPECIES.

Stipules not peltate; stipules and bracteoles ovate or oblong; wings a little longer than the standard; upper tooth of the calyx short, broad, truncate, emarginate. (Section Euphaseolus.)

Calyx teeth all shorter than the tube.

Legume flat, broad, falcate, 2 or 3 -seeded.

1. P. lunatus.

Legume linear, many-seeded, straight or slightly arcuate.

Bracteoles broad, equal to the calyx; peduncleshorter than the petiole.

Bracteoles narrow, shorter than the calyx, peduncle usually longer than the petiole.

Keel spirally twisted ( 3 or 4 times).

Keel slightly twisted.

The lowest calyx teeth narrow, subequal to or longer than the

tube.

Stipules often more or less peltate below the insertion; upper tooth of the calyx short, broad, truncate or emarginate; wings subequal to the standard. (Section Strophostyles.)

2. P. vulgaris.

Stipules not peltate; calyx subtubular, with 5 acute teeth; wings long-clawed, longer than the standard; legume narrow, reflexed. (Section Macroptiliu M.)

\section{Phaseolus lunatus I.}

3. P. caracalla.

4. P. antillanus.

5. P. adenanthus.

7. P. lathyroides.

Stems biennial, usually twining; leaflets 3 , the central one ovate-deltoid, 7 to $10 \mathrm{~cm}$. long, 5 to $7 \mathrm{~cm}$. broad, the lateral ones very unequal-sided; flowers in copious long or short stalked axillary racemes 2.5 to $10 \mathrm{~cm}$. long; calyx 2.2 to $3 \mathrm{~mm}$. deep; corolla under $1.5 \mathrm{~cm}$. deep; standard dull green, wings and keel pale blue or in the cultivated plant white; pod 5 to $7.5 \mathrm{~cm}$. long, 1.25 to $1.17 \mathrm{~cm}$. wide, glabrous, the upper suture slightly and the lower much recurved, dark violet, margins green; seeds purple or white.

Spontaneous and cultivated, near Coamo, in thickets at Farajones and in woods at Pedro Garcia; near Cabo Rojo, on hedges at Buena Vista; near Rincon, in thickets at Puntas; near Iguarlilla in gardens at Espinel. Cula, Jamaica (Grisebach), Haiti, St. Thomas (Eggers), St. (roix (do.), St. John (do.), Antigua (Grisehach), Guadeloupe, Dominica, Martinique, St. Vincent, Barbados, Trinidad (Kuntze), Margarita. Tropical America. Widely dispersed through the tropies of both hemispheres.

$P$. lunatus is easily clistinguished from $P$. vulgaris by its racemose inflorescence and its smaller flowers, pods, and bracts.

This plant is eultivated in Africa for the same purpose as $I$. vulgaris with us.

Local name, habus. Lima bean.

\section{Phaseolus vulgaris $\mathrm{L}$.}

(Urhan, 308.)

Stem amual, wide-climbing; leaflets 3 , the central one broad-ovate, 10 to $12.5 \mathrm{~cm}$. long, acute; peduncles in pairs, 2.5 to $5 \mathrm{~cm}$. long, 2 or 3 -flowered; pedicels 4.5 to 8.5 $\mathrm{mm}$. long; ralyx $0.6 \mathrm{~mm}$. deep; corolla white or lilac, $2.5 \mathrm{~cm}$. long; pod 10 to $12.5 \mathrm{~cm}$. long, $1.2 \mathrm{~cm}$. wide.

Cultivated near Adjuntas at Junco and near Mayaguez. P. vulgaris is a commonly cultivated species, not clearly known anywhere in a native state.

The home of the common bean, $P$. vulgaris, as Wittmack has shown, is south America, where nearly related species are also cultivated. Of this species there are innumerable varieties. The green pods are used as a vegetable in the form of "string" or 
"snap" beans. The mature seeds, of which there are a number of clifferent colors, are, on account of the abundance of legumin and starch, very nutritious, but also somewhat difficult to digest. They are consumed in large quantities, cooked in various ways, in Mexico, the United States, and Europe. A small white variety, the "navy bean," is used for victualing ships. The meal made from the seeds was formerly and is even yet used for poultices and is a component part of rouge.

Local name, habichuela.

\section{Phaseolus caraealla L.}

(Urban, 308.)

Stems woody at the base, high-twining, glabrous or subpubescent; stipules ovate or oblong; petiole often reaching 1 foot in length; leaflets usually $30 \mathrm{~cm}$. long, $10 \mathrm{~cm}$. wide, membranaceous; peduncle about $30 \mathrm{~cm}$. long; nodes thickened, pedicels about $1.2 \mathrm{~cm}$. long; flowers about $2.5 \mathrm{~cm}$. long, fragrant, purplish-lilac, or yellow and orange mixed; calyx about $1 \mathrm{~cm}$. long, large, often colored, glabrous; lobes short, broad, very obtuse, uppermost one bifid, all much shorter than the tube; petals all more or less twisted, keel 3 or 4 times twisted; legume straight, pendulous, $15 \mathrm{~cm}$. long, acuminate, glabrous, torulose.

Cultivated near Mayaguez.-Native country, South America.

Local name, caracol.

\section{Phaseolus antillanus Urb.}

(Urban, 309.)

Stems twining, 7 meters long; stipules oblong or obliquely ovate-oblong, 3 to $4 \mathrm{~mm}$. long, the apex obtuse; petiole with narrow and obliquely ovate stipels, reaching 2 $\mathrm{mm}$. in length; leaflets 3 , the central one triangular or ovate-oblong, shortly acuminate, 5 to $7 \mathrm{~cm}$. long, 3 to $5 \mathrm{~cm}$. wide with a petiolule 1 to $2 \mathrm{~cm}$. long, the lateral ones very unequal-sided, obliquely ovate, truncate at the base, with a petiolule 2 to $3 \mathrm{~mm}$. long, all membranaceous when dry, shortly and thinly pilose or subglabrous; peduncle 7 to $30 \mathrm{~cm}$. long, with 2 to 5 nodes above; bracts, ovate-oblong obtuse, 2 to $4 \mathrm{~mm}$. long; pedicel 1 to $2 \mathrm{~mm}$. long; calyx 5 to $6 \mathrm{~mm}$. long, glabrous or above thinly pilose, shortly ciliate on the margin; tube campanulate; lower segments triangular or ovate, obtuse, half as long as the tube, the lateral one somewhat longer, the uppermost one broadly truncate or slightly emarginate; flowers blue, 20 to $25 \mathrm{~mm}$. long, with a pedicel 1 to $2 \mathrm{~mm}$. long; standard broadly ovate, $20 \mathrm{~mm}$. long, $17 \mathrm{~mm}$. wide below, the apex rotundate, slightly emarginate, the claw $5 \mathrm{~mm}$. long; wings obovate-oblong, the apex subtruncate, 18 to $25 \mathrm{~mm}$. long; pod 8 to $13 \mathrm{~cm}$. long, 4 to $5 \mathrm{~mm}$. wide, thinly chothed with minute hairs, margin incrassate; seeds ovate-reniform, 3.5 to $4 \mathrm{~mm}$. long, $2.5 \mathrm{~mm}$. wide, convex, brown, often spotted with white.

Between Aibonito and Algarrobo on roadsides; near Juana Diaz in thickets towarl Escalabrado; near Guanica, in shady plains at Montalba; near Añasco on declivities at Ifatillo.-Cuba (Wright), Jamaica (Narch), Haiti (Buch), Martinique (Duss), St. Vincent (Smith).

Probably near $P$. peduncularis II. B. K., as well as can be determined from the very incomplete type specimen of that species.

\section{Phaseolus adenanthus G. F. W. Mey.}

(Urban, 308.)

Stem firm-herbaceous, wide-climbing; stipules $4.4 \mathrm{~mm}$. deep, broad, ovate, erect, persistent; petiole 3 to $6 \mathrm{~cm}$. long; leaflets 3 , the central one ovate, acuminate, 5 to $10 \mathrm{~cm}$. long, 2 to $3.5 \mathrm{~cm}$. wide, the lateral ones unequal-sided, the veins beneath slightly rufo-pubescent; flowers 6 to 12 in moderately dense axillary racemes on peduncles exceeding the leaves, white with large red spots; calyx $0.6 \mathrm{~mm}$. deep; corolla 
$2.2 \mathrm{~cm}$. deep, rose-red, rarely yellow and violet; pod 10 to $12.5 \mathrm{~cm}$. long, 6 to $8 \mathrm{~mm}$. wide, linear, compressed, slightly pubeseent, dark; seeds 12 to 15 .

Near Bayamon on the roadside and in hedges; near Cabo Rojo, in thickets toward Monte Grande; cultivated near Mayaguez; near Anasco, in thickets at Hatillo; near Aguadilla, at Vietoria.-Jamaica (Grisebach), Haiti, Guadeloupe, Martinique, St. Vincent, Tobago. Cosmopolitan in the tropies.

This plant is in its habit quite different from $P$. semiereetus. $P$. adenanthus is wide climbing, the other erect, twining above. The pod of $P$. semierectus is very narrow and subcylindrical, that of $P$. adenanthus widely linear and compressed. The flowers are larger than those of any other Ports Rican Phaseolus. In India the tuberous root is cooked and eaten, especially in time of famine.

Local name, habichuela cimarrona (Cook and Collins).

\section{(6. Phaseolus ovatus Benth.}

(Urban, 309.)

Stem climbing, slender, clothed with red-brown hairs; leaflets ovate or ovate-lanceolate, obtuse, 5 to $7.5 \mathrm{~cm}$. long, membranous, beneath or on both sirles pilose, becoming glabrous; stipules ovate or oblong, about $6 \mathrm{~mm}$. long, auriculate or subpeltate at the base; peduncle 7.5 to $12.5 \mathrm{~cm}$. long; bracts linear, subulate, pilose, caducous; calyx subsessile, a to $4 \mathrm{~mm}$. long, glabrous, the teeth shorter than the tube, the upper one broad, the lateral ones obtuse, lowest one subacute; flowers yellow; standard orbicular, 1.2 to $1.4 \mathrm{~mm}$. long; wings obovate, a little longer than the standard; beak of the keel spirally twisted; legume 2.5 to $3.5 \mathrm{~cm}$. long, $6 \mathrm{~mm}$. wide, compressed, later subterete; seeds ovate, compressed.

Near Mayaguez and near Vega Baja on the margins of the Yeguana Lake.-Cuba, Brazil, Uruguay.

\section{Phaseolus lathyroides I. a}

(Urhan, 310.)

Stem erect or twining above, sericeous or glabrescent; leaflets broadly ovate or sublanceolate; 2.5 to $5 \mathrm{~cm}$. long, 1 to $2 \mathrm{~cm}$. wide; stipules lanceolate, setaceo-acuminate, striate, 4 to $6.5 \mathrm{~mm}$. long; petiole 2 to $3.5 \mathrm{~cm}$. long; peduncle elongated, 15 to $30 \mathrm{~cm}$. long, flowering part 5 to $7.5 \mathrm{~cm}$. long; calyx $6 \mathrm{~mm}$. deep; corolla purple, 1.3 to $1.7 \mathrm{~cm}$. deep; pod narrowly linear, erect, subcylindrical, 7 to $11 \mathrm{~cm}$. long, $4 \mathrm{~mm}$. wide, manyseeded.

Near Bayamon in rocky and dry places; near Aibonito, at La Lima; in Maricao in the streets; near Mayaguez. - Bahama, Cuba, Jamaica, Cayman, IIaiti, St. Thomas, St. Croix (Eggers), St. John (do.), Intigua, Guadeloupe, Martinique, St. Vineent, Bequia, Mustique (Kew Bull. no. 81, p. 247), Barbados, Grenada, Curaçao. Indigenous in tropical America; distributed over the tropies of the whole world.

Sintenis collected under the no. 5854 and under the name habichuelas a cultivated species of Phaseolus, which can not be determined because its flowers are faded and deformed. Is this not perhaps P. multiflorus Willd.?

\section{VIGNA Savi.}

Vigna SAvi, Osserv. Plas. 3: 7. 1824.

Callicysthus Endu. Prod. Fl. Norfolk 90. 1833.

Scytalıs E. MEY. Comm. Pl. Afr. Austr. 144. 1835.

Calyx campanulate or subtubuliform, the two upper lobes free or connate; standard suborbicular, the base appendiculate, with inflexed auricles; wings falcate-obovate,

$a$ Cook and Collins, p. 216, as Phaseolus semiereetus. 
rather shorter than the standard; keel almost as long as the wings, truncate, or beaked at the tip, but the point not spiral; upper stamens free, the others united; ovary sessile, multiovulate; style filiform, dilated upwards, longitudinally bearded on the inner side upwards; stigma very oblique; pod linear, straight or slightly recurved, subterete, 2-valved, filled within between the seeds; seeds reniform, quadrate.-Herbs, either prostrate and trailing or twining or more rarely somewhat erect; leaves pinnate; leaflets 3 , stipellate; stipules usually persistent, rarely produced below their insertion; flowers greenish yellow, more rarely purple, in axillary racemes; bracts and bracteoles usually very deciduous.

\section{KEY TO THE SPECIES.}

Calyx teeth linear-lanceolate, equaling the tube; stem and leaflets clothed with adpressed, strong, silky hairs; terminal leaflet lanceolate or ovate-lanceolate; peduncles 7.5 to $30 \mathrm{~cm}$. long, 2 to 4-flowered; corolla reddish-purple, $2.5 \mathrm{~cm}$. long, conspicuously veined; keel prolonged into an incurved beak; por linear,

7.5 to $10 \mathrm{~cm}$. long, silky, recurved.

Calyx teeth deltoid; shorter than the tube.

Pod 3.7 to $5 \mathrm{~cm}$. long, $6 \mathrm{~mm}$. broad, slightly recurved, glahrescent or thinly silky, 8 to 10 -seeded; seeds shiny, brown with white hilum; terminal leaflet ovate, acute, 5 to 7.5 ('m. long, both sides glabrous; stipules not spurred; flowers 12 to 20 in a conical raceme on a glabrous peduncle 5 to $10 \mathrm{~cm}$. long; corolla pale yellow, 11 to $13 \mathrm{~mm}$. long.

1. T. vexillata.

Pod pendulous, 15 to $30 \mathrm{~cm}$. long, $9 \mathrm{~mm}$. broad, subcom-

2. V.repens. pressed, 10 to 15-seeded, slightly torulose when fully matured; seeds white, red, or black; terminal leaflet roundish or ovate, 7.5 to $15 \mathrm{~cm}$. long, both sides glabrous; stipules comparatively large, distinctly spurred; flowers in 6 to 12 -flowered racemes, on glabrous peduncles 15 to 30 cm. long; corolla yeilow or reddish, $2.5 \mathrm{~cm}$. deep.

3. V. ungurculata.

1. Vigna vexillata (L.) A. Rich.

(Urban, 310.)

Stem herbaceous, wide climbing; terminal leaflet 5 to $7.5 \mathrm{~cm}$. long; petiolule 1 to $1.8 \mathrm{~cm}$. long, flowers white inside, becoming blue; calyx 1 to $1.5 \mathrm{~cm}$. deep.

Near Bayamon in meadows and on roadsides; between Aguas Buenas and caguas on roadsides.-Cuba, Haiti, St. Vincent, Grenada. This species is widely spread over tropical Asia, Africa, and America.

This plant on account of the obliquity of the flower and the length of the beak is intermediate in some respects between Vigna and Phaseolus, and has been placed alternately by botanists in either of these genera or in Iolichos, or it has been proposed as a distinct genus.

Local name, frijol cimarrón.

2. Vigna repens (L.) O. Kuntze. $a$

(Urban, 311.)

Stems very slender, wide-twining, glabrous; petiole 2.5 to $5 \mathrm{~cm}$. long; stipules minute, lanceolate, not spurred; leaflets 3 , membranous, both sides glabrous, the end one ovate, acute, 5 to $7.5 \mathrm{~cm}$. long; petiolule 0.8 to $1.6 \mathrm{~cm}$. long; lateral ones unequalsided; flowers up to 12 or 20 in a conical raceme on a glabrous peduncle 5 to $10 \mathrm{~cm}$. 
long, yellow; pedicel $2 \mathrm{~mm}$. long; bracts and bracteoles very minute; calyx campanulate, glabrous, $4 \mathrm{~mm}$. deep; teeth deltoid, shorter than the tube; corolla 1 to 1.2 $\mathrm{em}$. long; standard glabrous on the back; pod 3.7 to $5 \mathrm{~cm}$. long, slightly recurved, glabrescent or thinly silky.

Near Bayamon in grassy plains; near Patillas in coast districts at Gu - daraya; near Sabana Grande, on the bank of Estero River; near Salinas de Cabo Rojo at Los Morillos; near Mayaguez; in coast districts at Algarrobo; near Manati in meadows near the seashore--Bermuda (Hemsley), Cuba, Jamaica, Cayman (Hitcheock), Haiti, St. Thomas, St. Croix, St. John (Eggers), Antigua (Grisebach), Guadeloupe, St. Vincent, Bequia (Kew Bull. No. 81, p. 247), Barbados, Grenada, Tobago. This species is common from temperate North America to Argentina. Tropical and south Africa, tropical Asia, and Australia.

3. Vigna unguiculata (L.) Walp.

(Urban, 311.)

Stems annual, twining, subglabrous; stipules ovate-lanceolate, subpeltate, 0.8 to $1.2 \mathrm{~cm}$. deep; petioles 5 to $15 \mathrm{~cm}$. long, glabrous; leaflets 3 , the central one roundish or ovate, 7.5 to $15 \mathrm{~cm}$. long, acute, the base rounded; petiolule 2.5 to $5 \mathrm{~cm}$. long, lateral ones often unequal-sided, both sides glabrous; flowers in 6 to 12 -flowered racemes on glabrous peduncles 15 to $30 \mathrm{~cm}$. long; bracts like the stipules; pedicels very short; calyx glabrous, $4 \mathrm{~mm}$. deep; teeth deltoid, acuminate, shorter than the tube, the two upper ones connate; corolla yellow or reddish, $2.5 \mathrm{~cm}$. deep.

Cultivated near Yabucoa, at Guayavote, and near Mayaguez. Universally cultivated throughout the Tropics.

Two varieties occur, one with lilac flowers and yellow seeds spotted with red, the other with yellow standard, purplish white wings, and white or pale yellow seeds which are brown at the hilum.

The pods and seeds are eaten and the fibers of the long peduncles are used for ropes, nets, and cloths.

Local names, frijoles, lentejas.

66. PACHYRHIZUS Rich.

Cacara Rumph.; Thou. Dict. Sc. Nat. 6: 35.1806.

Pachyrhizus Rıсн.; DC. Mem. Legum. 379. 1825.

Taeniocarpum. Desv. Ann. Sc. Nat. 9: 420. 1826.

Calyx campanulate, the two upper teeth subconnate, the others equal, lanceolate; standarl broadly obovate, appendiculate at the base with inflexed auricles; wings oblong, falcate; keel incurved, obtuse, equaling the wings; stamens diadelphous or monadelphous; ovary subsessile, multiovulate; style moderately thick, the apex subinvolute, flattened on the inner side; stigma subglobose, oblique; pod linear, subcompressed, depressed transversely between the seeds and septate within, 2valved.- Ilerbs, twining; leaves pinnate; leaflets 3, usually more or less sinuatedentate, stipellate; flowers in clongated, sometimes panicled axillary racemes; bracts and bracteoles minute, setaceous, deciduous.

KEY TO THE SPECIES.

Root a turnip-like tuber; corolla blue; pod 15 to $22.5 \mathrm{~cm}$. long. P. erosus.

Root of long cord-like fibers bearing a succession of tubers; flowers white; pod 20 to $30 \mathrm{~cm}$. long.

P. tuberosus. 


\section{Pachyrhizus erosus (L.) Urb.a}

(Urban, 311.)

Root a tuber like a turnip; stems perennial, firm, wide-twining, subglabrous; stipules small, linear or lanceolate; petioles firm, 5 to $15 \mathrm{~cm}$. long; leaflets roundish, usually more or less rhomboidal, often sinuate-lobate, 10 to $15 \mathrm{~cm}$. each way, both sicles glabrous or the lower with thinly adpressed gray-silky hairs when young; flowers in ample racemes 10 to $15 \mathrm{~cm}$. long, on firm pecluncles often equaling them; pedicels 4 to $6 \mathrm{~mm}$. long; calyx 6.5 to $8.5 \mathrm{~mm}$. deep, silky, the teeth reaching about halfway down; corolla blue, $2.5 \mathrm{~cm}$. deep or more; pod 15 to $22.5 \mathrm{~cm}$. long, 17 to $19.5 \mathrm{~mm}$. wide, glabrescent, subcompressed, distinctly constricted vertically, 9 to 12-seeded; seeds compressed-roundish.

Near Bayamon; near Las Piedras; near Aguada, in mountain woods at Rio Grande; near Aguadilla on mountain slopes.-Cuba (Grisebach), Haiti, St. Thomas, Guadeloupe, Dominica (Grisebach), Nartinique, St. Vincent (Kew Bull. no. 81, p. 247), Bequia. Native country not clearly known.

This plant is not only widely distributed in the tropics of Asia and America, but is often cultivated on account of its tuberous root, which resembles a turnip, and is eaten raw or cooked.

Local name, habilla.

\section{Pachyrhizus tuberosus (Lam.) Spreng.}

(Urban, 312.)

Herb twining, 3 to 6 meters high; root consisting of a number of simple cord-like fibers, several feet in length, stretching under the surface of the ground, bearing in their course a succession of tubers; leaflets subentire or slightly sinuate (in the young leaves sometimes deeply lobed); raceme almost simple, the lower branches very short, many-flowered; flowers white; pod 20 to $30 \mathrm{~cm}$. long, 1.8 to $2 \mathrm{~cm}$. broad, constricted between the seeds; seeds red.

Cultivated near Rincon in Hacienda La Palmira. Native country unknown. Mr. Oliver says "I think this plant may well be a variety of $P$. angulatus Rich. originated under cultivation, but so marked as to require a distinct name for cultural purposes, and for the present the specific name given by Lamarck may suitably be adopted."

Cultivated for its large edible tubers. It can be planted at any season of the year, and the roots are fit for digging in 4 or 5 months. The pods of this plant the yam bean), according to Dr. Trimen, are an admirable vegetable, superior to ordinary French beans in the absence of a fibrous string about the sutures of the pod. The seeds are poisonous. Macfadyen says in the Flora of Jamaica, "The tubers may either be boiled plain, in which state they are a very good substitute for yams and other roots in common use, or they may be submitted to a process similar to arrowroot, and a starch obtained. This starch is pure white and is equal in every respect to arrowroot."

\section{DOLICHOS L.}

Dolichos L. Sp. Pl. 2: 725. 1753.

Macrolyloma Wight \& Arn. Prod. Fl. Pen. Ind. Or. 1 : 248. 1834.

Dolichus E. NEY. Comm. Pl. Afr. Austr. 140. 1835.

Calyx campanulate, the 2 upper teeth united into one entire or emarginate one; standard orbicular, the thickened base appendiculate with inflexed auricles; wings falcate-obovate, adhering to the keel; keel much incurved, usually rostrate, but not 
spiral; upper stamen free, often appendiculate or incrassate near the base; anthers uniform; ovary subsessile, multiovulate; style thickened upwards, either bearded longitudinally on the inner side or hairy all around, at least around the stigma, which is small and terminal; pod linear or broadly oblong, compressed, straight or curved, the sutures incrassated, the valves nearly flat or slightly convex; seeds thick, compressed. Twining, trailing, or erect shrubs or undershrubs; leaves pinnate; leaflets 3 , stipellate; stipules usually small; flowers violet, flesh-colored, yellowish or whitish, sometimes solitary or fascicled, sometimes in racemes; bracts and bracteoles striate, usually small.

\section{Dolichos lablab L.}

(Urban, 312, as Lablab vulgaris Savi.)

A wide-climbing perennial with subglabrous stem; leaflets membranous, central one ovate-deltoid, 7.5 to $10 \mathrm{~cm}$. long, broadly spatulately narrowed at the base; flowers in racemes, 7.5 to $15 \mathrm{~cm}$. long; calyx 3.3 to $6.5 \mathrm{~mm}$. long, subglabrous; corolla 1.5 to 1.9 $\mathrm{cm}$. deep, reddish or pale, keel abruptly incurved; style flattened upwards, not twisted, narrowed at the base; pod 3.5 to $5 \mathrm{~cm}$. long, $2 \mathrm{~cm}$. broad, narrowed at the base, the upper suture nearly straight, the faces glabrescent, rarely persistently pubescent; seeds 2 to 4 .

There occur also three varieties, one with white flowers, variety albiflorus DC., the second with purple flowers, variety purpureus DC., and the third with rose-colored flowers.

Cultivated and seemingly wild at Bayamon in gardens; near Caguas; near Mayaguez; cultivated near Rincon and also near Aguadilla, at Espinal-Bahama (Hitcheock), Cuba (Grisebach), Jamaica, St. Croix, St. Bartholomew (Euphrasén), St. Kitts (Grisebach), Antigua (do.), Guadeloupe, Martinique, St. Vincent, Bequia (Kew Bull. no. 81, p. 247). In the tropies of both hemispheres. Native country probably tropical Africa (Bentham).

This plant is universally cultivated in the tropics, where the young pods and the black or brown seeds are used as a vegetable.

Local names, frijoles caballeros, chicharos, cicero. 


\section{INDEX OF GENERA INI) COUUON NAUES.}

(Synonyms of genera in italics.)

\begin{tabular}{|c|c|c|c|}
\hline \multicolumn{2}{|c|}{ Page. } & \multicolumn{2}{|c|}{ Page. } \\
\hline eacia . & 144 & Cajan........ & 210 \\
\hline & 145 & Cajanum. . & 210 \\
\hline & 1 & & \\
\hline ... & 144 & & 143 \\
\hline canthonotus. & 172 & & 216 \\
\hline & & $\mathrm{m} \ldots \ldots \ldots \ldots \ldots \ldots$ & 206 \\
\hline tera.... & & ............ & 168 \\
\hline e............. & & & 164 \\
\hline & & & 157 \\
\hline$\ldots \ldots \ldots \ldots \ldots \ldots \ldots \ldots \ldots \ldots \ldots \ldots$ & & na & $15 s$ \\
\hline & & $\ldots \ldots$ & 209 \\
\hline & & & 209 \\
\hline & & 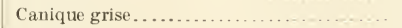 & 166 \\
\hline nico........................ & & $\ldots . . .$. & 215 \\
\hline 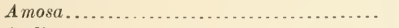 & & ....... & 178 \\
\hline & & & 171 \\
\hline & & & 172 \\
\hline n.......... & & $\cdots$ & 171 \\
\hline & & & 172 \\
\hline & & . & 155 \\
\hline$\ldots \ldots \ldots \ldots \ldots \ldots \ldots \ldots \ldots \ldots \ldots \ldots \ldots \ldots$ & & ..... & 145 \\
\hline 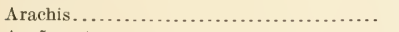 & & & 145 \\
\hline & & (2) & 141 \\
\hline & & 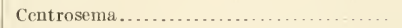 & 199 \\
\hline fs $\ldots \ldots \ldots \ldots \ldots \ldots \ldots \ldots \ldots$ & & & 168 \\
\hline …........................ & & ...... & 220 \\
\hline & & & 220 \\
\hline 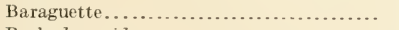 & & ...... & 168 \\
\hline (n) & & .......... & 198 \\
\hline (n....................... & & ........ & 152 \\
\hline (n) & & … & \\
\hline$\ldots \ldots \ldots \ldots \ldots$ & & (n............ & \\
\hline (n) & & (n) & \\
\hline . & & ... & 150 \\
\hline & & ........ & 200 \\
\hline -. & & ...... & 201 \\
\hline 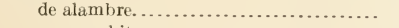 & & rican. & 152 \\
\hline n............... & & & 144 \\
\hline & & ......... & 150 \\
\hline & & $\cdots$ & 159 \\
\hline & & & 177 \\
\hline . & & ..... & 177 \\
\hline & & ...... & 15 \\
\hline & & & 15 \\
\hline , & & & 32 \\
\hline & & cowitch.... & 205 \\
\hline & & $\ldots \ldots \ldots \ldots \ldots$ & 178 \\
\hline & & ois..... & 209 \\
\hline (2) & & gallo...... & 179 \\
\hline chi............................ & & blanco........................ & 202 \\
\hline 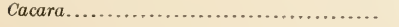 & 218 & 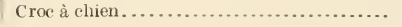 & 167 \\
\hline
\end{tabular}


Page.

('rotala ria.

Cuatcumaya. . .

Cuernecillo.

Cyanostremma....

Crnometria.

Cynomora .

Ditluergia .

Darwinia

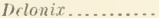

Desmanthea...

Desmantlius...........

Desmanto a marillo. rayado.

Desinodium...............................

Dioclea.............

Dolicholus............

Dolichos. . .

Dolichus....

Dormidera.

Dragon's blood, American

Drepanocarpus............

Dudeldu .

Enredadera.

Entada...

Erythrina

Erythrine de cayenne.

Escambron colorado.

Escobilla

Espiga de amor..

Fernamboue

Flamboyán

blaneo...

colorado

Fleurs de paradis

Flor de pito

$$
\text { rayo. }
$$

Flower fence.

$$
\text { of Barbados }
$$

Forte ventura.

Frijol cimarron

Frijoles.

$$
\text { caballeros. }
$$

Frijolillo.

Fustic

Galaetia

Gallito...

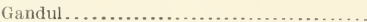

Gandures.

Gendarme.

Geno ................

Gliricidia.

Goober.

Gonsii...

Gray nickars.

Groundnut.

Guaba.

Guacalote amarillo. prieto.

Guama ...

Guava

Habas..

Habichuela.

$$
\text { eimarrona }
$$

Habichuelas.

IIabilla.

Haematoxylum age.

16 is

147

206

151

151

192

173

179

16.5

148

148

149

148

184

209

277

219

219

160

194

193

168

176

150

202

203

142

161

167

167

143,165

154

165

168

199,201

164

168

168

196

217

218

220

213

181

206

179

211

211

167

195

176

184

149

$166^{\circ}$

184

141

167

166

141

141

214

215

216

216

219

164
Page.

159

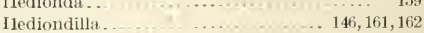

IIemidesma ..... . ................. 148

Ilerminiera ......................... 181

Hoepfneria ....................... 197

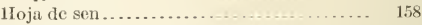

Horse eye................... 166

Hymenaea ............... . . . . . . . 152

Hymenospron..................... 209

Immortel jaune................ 203

Indigo . . . . . . . . . . . . . . . . . . 173

Indigoferw................... 172

Inga ........................ 140

Iripa ...................... 151

Jatahy....................... 152

Jatobá ......................... 152

Jerusalem thorn............ ........... 164

Jicama........................... 206

Junquillo...................... 190

Jutahy................... 152

Krameria....................... 163

Lentejas..................... 218

Leptoglottis ................... 146

Lima bean.................. 214

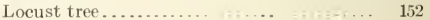

Lomoplis......................... 147

Lonehocarpus........................ 194

Lucaena........................ 146

Macrotropis ........................... 168

Macrotyloma ................. 219

Madera negra...................

Madre de cacao....................... 176

Mani .............................. 185

Manila nut ................... 184

Manna................... 157

Maray-maray....................... 193

Mariposa.................... 154

Mata raton......................... 176

Mato ....................... 150, 209,206

azul.............. 166

colorado ......................... 150,210

de la playa...................... 210

de playa.......................... 166

Maton.............................. 176

Matos........................... 169, 205

de playa........................ 167

del monte............... - . . ... 205

Matraca........................... 171

Meibomia........................... 185

Membrillo............................. 193

Metrocynia .......................... 151

Mimosa............................... ${ }^{147}$

Moca .......................... . 197

blanea ........................ 197

Morir vivir........................ 147

Morongin .................................... 146

Mouricou.......................... 202

Moutouchi....................... 194

Moutouchia .................. . . . 194

Mueuna................ _ _ . 204

Mundubi.................. 1,4

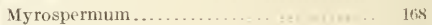

Nephrosis................... 193

Neptunia.......................... 148

Neuroscapha....................... 194 
Page.

Pagee.

Nickars.

gray.

\section{6}

166

167

206

166

Eil de chat

ojo de buey.

$$
\text { de costa. }
$$

Ormosia .

Orucaria...

Pachy rhizus.

Palo de boyo.

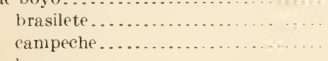

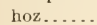

mato.

matos.

pollo

rayo....

hediondo.

Papito.

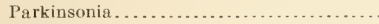

Parosela ................................

Peanut........................... 184

butter......................... 184

Peñon de Cuba........................ 203

Pequeño.......................... 213

Peronia......................... 169, 198

Peronias.............................. 213

Peronilas........................ 150, 198

l'haseolus.......................... 213

Phyllodoce........................... 144

Pica-piea........................... 205

Piptadenia .......................... 150

Piscidia.............................. 196

Pithecolobium......................... 141

Pleurolobus......................... 185

Poincellade......................... 168

Poincia.............................. 160

Poinciade.......................... 168

Poinciana............................. 165

Polisandro.......................... 152

Pterocarpus........................... 194

Quapinole........................ 152

Quashi............................ 166

Resina copal....................... 152

courbaril........................ 152

Retama......................... 161,177

Rhynchosia.......................... 211

Rolon............................. 142

Rudolphia.......................... 203

Rynchosia ......................... 211

Saman............................ 142

Sassa............................. 144

Schleinitzia........................ 150

Schranckia........................ 146

Schrankia.......................... 146
Scytalis . . . . . . . . . . . . . . 216

Sen del pais........................ 158, 159

Senna, wild ........................... 168

Sensitiva.................. 147

Sensitive plant........

Sereipo.................................... 168

Sesbania............................ 179, 180

Seplina ..................... 154

Sonajuelas...................... 171

Sophora.................. 169

Spanish carnation............... 16id

Sphaeridiophorum................. = .... 172

Sphinctolobium...................... 194

Spiroloba......................... 141

Stachychrysum...................... 149

Stahlia............................... 151

Stenolobium..................... 206

Stylosanthes..................... 183

Sueetia.................... . .

Tachuelo........................... 181

Taeniocarpum....................... 218

Talantalo.......................... 160

Talantro............................ 160

Tamarindillo.................. . 151,162

Tamarindo....................... 153

cimarron........................ 145

Tamarindus........................ 152

Tanroujou .......................... 152

Tembeta............................ 152

Teramnus.......................... 201

Tortera ................................. 206

Toxotropis......................... 177

L'ña de gato.................... 142

Varietal............................ 154

Ventura............................. 196

Vigna............................... 216

Vouacapoua.......................... 196

Wild senna........................ 168

Yerba de cienega...................... 182 contrabando .................... 192

hedionda macho ................... 159

rosario..............

Yeux de chat .................. 166

Zarza..................... 145, 167

Zarza boba........................ 144

Zarzabacoa.................... 161, 189, 190 cola de escorpion. ............ 191 de dos hojas........................ 185 de monte..................... 188 de tres flores............... 187 enana............................ 184

espiral.............................. 191

galana........................ 188

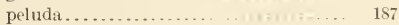

Zonaria........................... 185

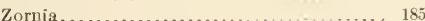





1 
.

$1+2$

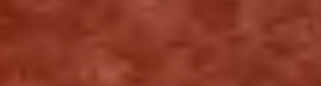

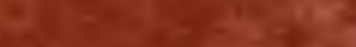

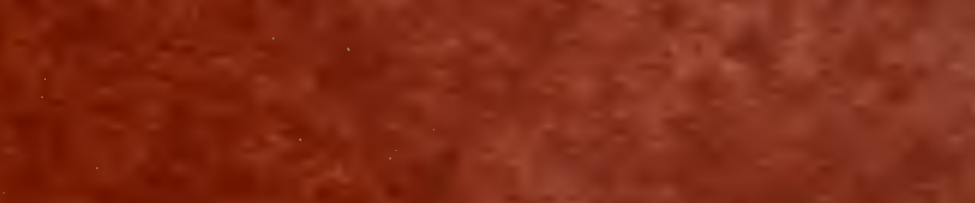

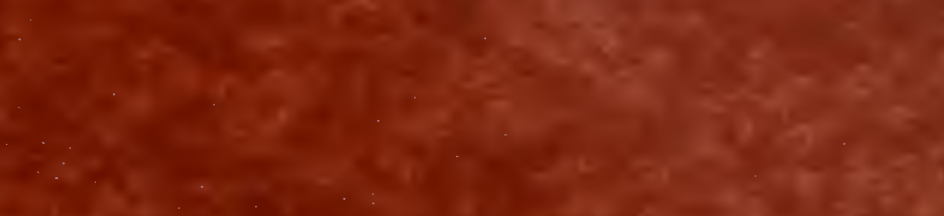

.

$\therefore$

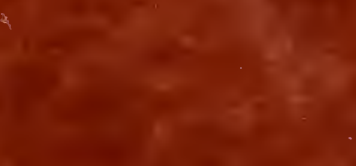

$\sqrt{3}+2$

$+4$

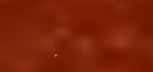

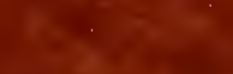
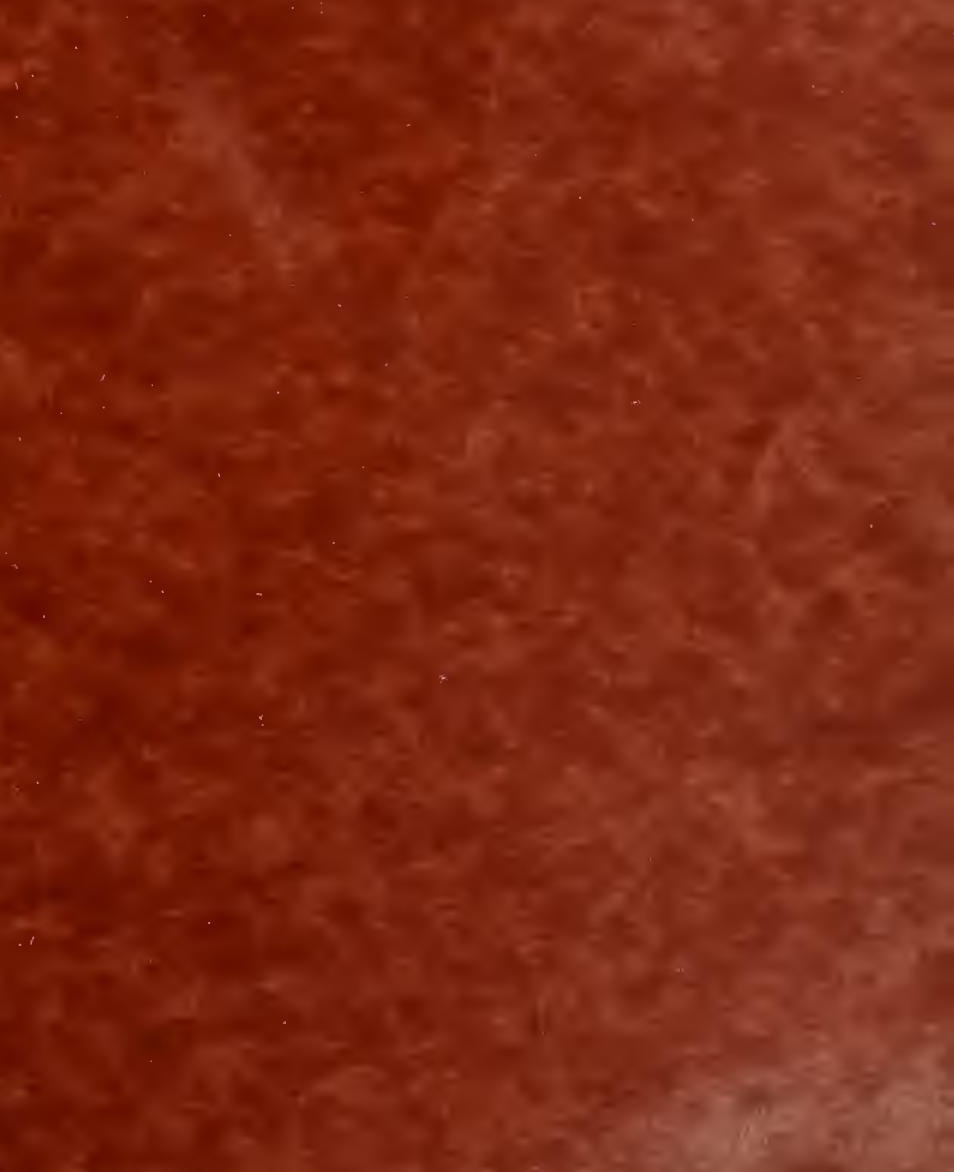

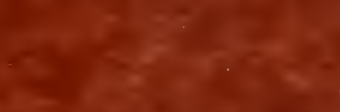

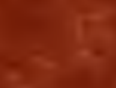

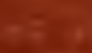

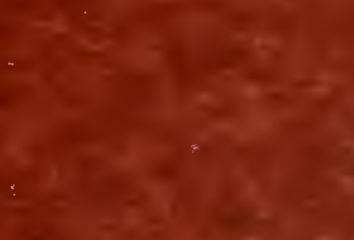




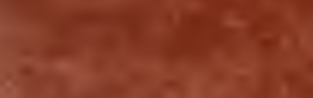

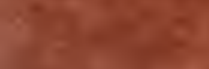

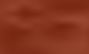

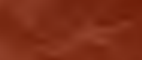

